Prepared in cooperation with the Missouri Department of Natural Resources

General Water-Quality Conditions, Long-Term Trends, and Network Analysis at Selected Sites within the Ambient Water-Quality Monitoring Network in Missouri, Water Years 1993-2017

Scientific Investigations Report 2021-5079 



\section{General Water-Quality Conditions, Long-Term Trends, and Network Analysis at Selected Sites within the Ambient Water-Quality Monitoring Network in Missouri, Water Years 1993-2017}

By Joseph M. Richards and Miya N. Barr

Prepared in cooperation with the Missouri Department of Natural Resources

Scientific Investigations Report 2021-5079 


\section{U.S. Geological Survey, Reston, Virginia: 2021}

For more information on the USGS —-the Federal source for science about the Earth, its natural and living resources, natural hazards, and the environment-visit https://www.usgs.gov or call 1-888-ASK-USGS.

For an overview of USGS information products, including maps, imagery, and publications, visit https://store.usgs.gov/.

Any use of trade, firm, or product names is for descriptive purposes only and does not imply endorsement by the U.S. Government.

Although this information product, for the most part, is in the public domain, it also may contain copyrighted materials as noted in the text. Permission to reproduce copyrighted items must be secured from the copyright owner.

\section{Suggested citation:}

Richards, J.M., and Barr, M.N., 2021, General water-quality conditions, long-term trends, and network analysis at selected sites within the Ambient Water-Quality Monitoring Network in Missouri, water years 1993-2017: U.S. Geological Survey Scientific Investigations Report 2021-5079, 75 p., https://doi.org/10.3133/sir20215079.

Associated data for this publication:

Richards, J.M., and Barr, M.N., 2021, Supporting data for analysis of general water-quality conditions, long-term trends, and network analysis at selected sites within the Ambient Water-Quality Monitoring Network in Missouri, water years 1993-2017: U.S. Geological Survey data release, https://doi.org/10.5066/P9R2R9DF.

U.S. Geological Survey, 2020, USGS water data for the Nation: U.S. Geological Survey National Water Information System database, https://doi.org/10.5066/F7P55KJN.

ISSN 2328-0328 (online) 


\section{Acknowledgments}

Authors would like to thank Robert Voss from the Missouri Department of Natural Resources for his assistance, advice, and suggestions during data analysis.

The authors would also like to acknowledge the contribution of the following U.S. Geological

Survey employees: Jordan Wilson for the programming assistance and Morgan Spring for the dataset editing that they provided during the data analysis. 



\section{Contents}

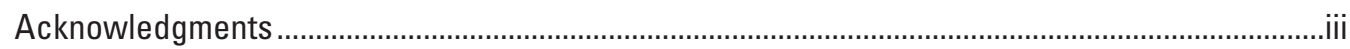

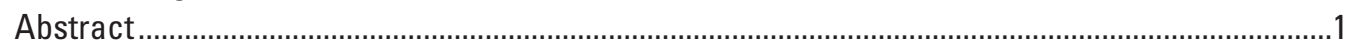

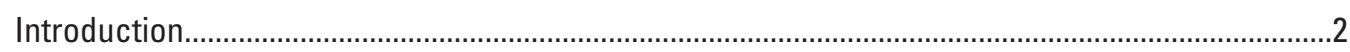

The Ambient Water-Quality Monitoring Network................................................................2

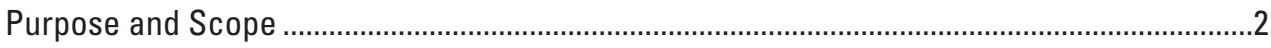

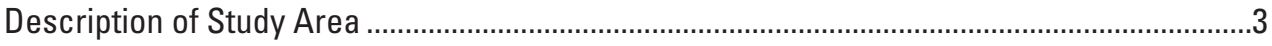

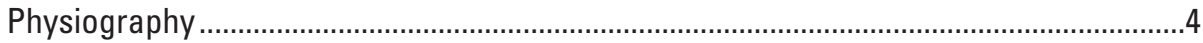

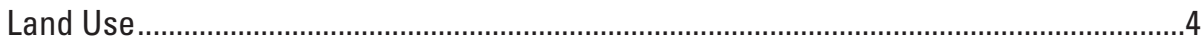

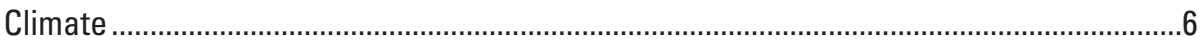

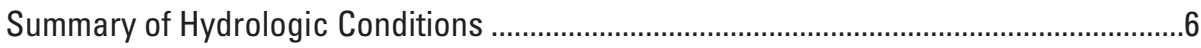

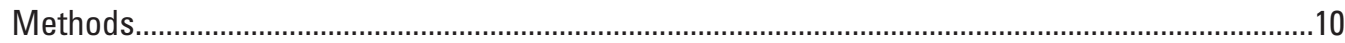

Description and Classification of Sites in the Sampling Network ......................................10

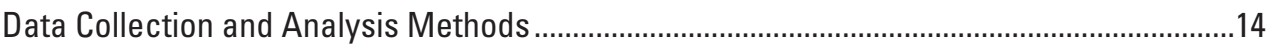

Water-Quality and Discharge Data Analysis Methods...........................................................14

Data Retrieval and Conditioning................................................................................14

Long-Term Trends and Other Analysis ..................................................................... 15

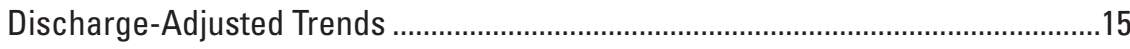

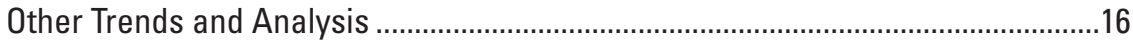

Graphical Analysis ...................................................................................16

Nonparametric Spearman's Rank Correlation Coefficient ...............................16

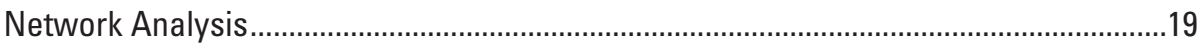

Discharge Data Range Evaluation ...................................................................19

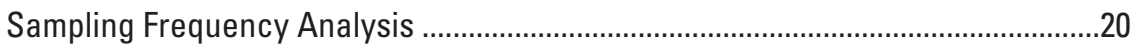

Trends from Simulated Reduced Frequency Dataset .............................................21

Continuous Discharge Estimation at Ungaged AWOMN Sites .................................21

Potentially Redundant Site Determination in the AWOMN ......................................22

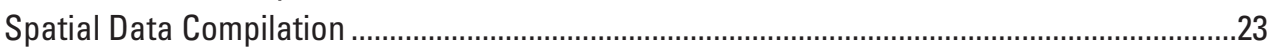

General Water-Quality Conditions, Long-Term Trends, and Network Analysis ...............................23

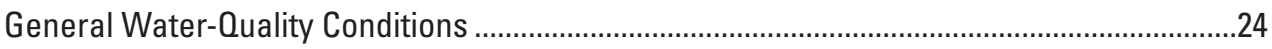

Long-Term Trends and Other Analysis ..................................................................................24

Long-Term Discharge-Adjusted Trends in Selected Water-Quality Constituents ..........24

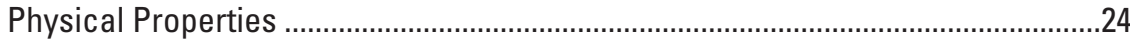

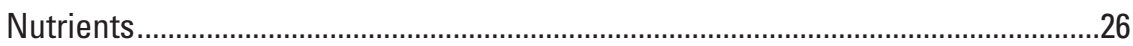

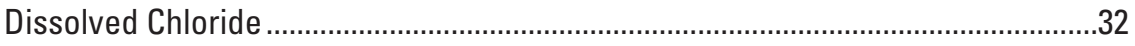

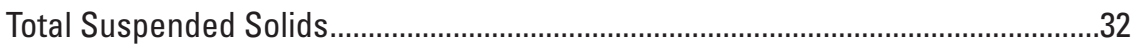

Fecal Indicator Bacteria ............................................................................................36

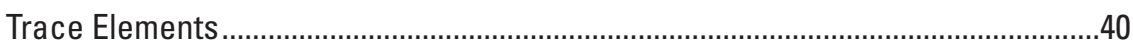

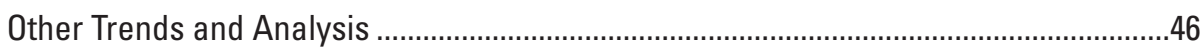

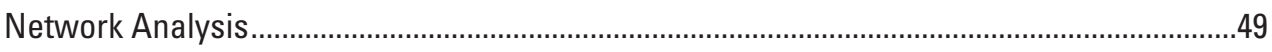

Discharge Data Range Evaluation ............................................................................

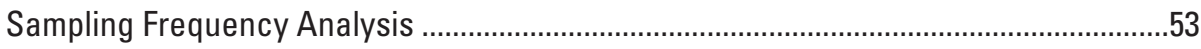

Trends from Simulated Reduced Frequency Dataset.....................................................63

Continuous Discharge Estimation at Ungaged AWOMN Sites .......................................64

Potentially Redundant Site Determination in the AWOMN .........................................66

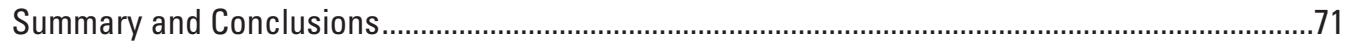

References Cited.............................................................................................................. 


\section{Figures}

1. Map showing location of Ambient Water-Quality Monitoring Network sites in Missouri 3

2. Map showing physiographic regions of Missouri........................................................

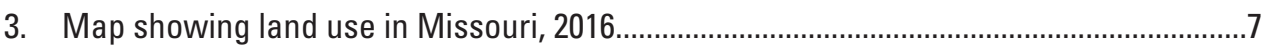

4. Graphs showing departure from mean precipitation and temperature in Missouri 1895-2018 from the Missouri Climate Center (2019).

5. Graphs showing annual and seasonal discharge yield for 7-day minimum, mean, and 1-day maximum for water years 1993 through 2017 at site 38 produced by the EGRET software

6. Map showing drainage basin boundaries of the Ambient Water-Quality Monitoring Network sites in relation to the 4-digit hydrologic unit code subregions in Missouri

7. Boxplot examples of constituent data distribution by month and season for nitrate plus nitrite at site 38 .

8. Scatterplot examples for site 38

9. Map showing distribution of the median concentration of total phosphorus calculated for water years 1993 through 2017 at the Ambient Water-Quality Monitoring Network sites in Missouri

10. Graphs showing water temperature trends for selected sites in the Missouri Ambient Water-Quality Monitoring Network

11. Graphs showing dissolved oxygen trends for selected sites in the Missouri Ambient Water-Quality Monitoring Network

12. Graphs showing specific conductance trends for selected sites in the Missouri Ambient Water-Quality Monitoring Network.

13. Graphs showing $\mathrm{pH}$ trends for selected sites in the Missouri Ambient Water-Quality Monitoring Network

14. Graphs showing dissolved nitrate plus nitrite, as nitrogen, trends for selected sites in the Missouri Ambient Water-Quality Monitoring Network

15. Graphs showing total phosphorus trends for selected sites in the Missouri Ambient Water-Quality Monitoring Network

16. Graphs showing dissolved phosphorus trends for selected sites in the Missouri Ambient Water-Quality Monitoring Network....

17. Graphs showing dissolved chloride trends for selected sites in the Missouri Ambient Water-Quality Monitoring Network.

18. Graphs showing total suspended solids trends for selected sites in the Missouri Ambient Water-Quality Monitoring Network.

19. Graphs showing fecal coliform trends for selected sites in the Missouri Ambient Water-Quality Monitoring Network

20. Graphs showing Escherichia colitrends for selected sites in the Missouri Ambient Water-Quality Monitoring Network.

21. Graphs showing dissolved lead trends for selected sites in the Missouri Ambient Water-Quality Monitoring Network.....

22. Graphs showing total recoverable lead trends for selected sites in the Missouri Ambient Water-Quality Monitoring Network

23. Graphs showing dissolved zinc trends for selected sites in the Missouri Ambient Water-Quality Monitoring Network. 
24. Graphs showing total recoverable zinc trends for selected sites in the Missouri Ambient Water-Quality Monitoring Network

25. Boxplots showing example of different discharge distribution for two constituents at site 38 , that are sampled at a different frequency.

26. Graphs showing water temperature trends computed from data resampled from monthly to quarterly frequency using the months March, June, September, and December

27. Graph showing comparison of estimated versus measured discharge for a short period surrounding a gap in the daily mean discharge record at site 39

\section{Tables}

1. Site number, U.S. Geological Survey station number, name, and general site information for Ambient Water-Quality Monitoring Network sites in Missouri

2. Land use in 2016, change in land-use categories between 2001 and 2016, and mean annual discharge from water year 1993 through 2017 for sites in the Missouri Ambient Water-Quality Monitoring Network

3. Drainage area, density of Ambient Water-Quality Monitoring Network sites, and rank of site density for the sites in each of the 4- and 8-digit hydrologic unit code areas

4. Simulated sampling frequency groups, number of statistically significant differences, and rank of the simulated sampling frequency groups

5. Basin-specific information for the sites in the Ambient Water-Quality Monitoring Network

6. Summary of trend results for select physical properties and chemical constituents at sites in the Missouri Ambient Water-Quality Monitoring Network and other select sites, January 1993 through December 2017

7. Escherichia coli population densities by geometric mean for recreational season and median values computed from water sample results in comparison to State standards at study sites where a statistically significant trend was identified, January 1993 through December 2017.

8. Analysis of the water-quality constituents versus time using the Spearman correlation coefficient and the $p$-value

9. Analysis of the water-quality constituents versus discharge using the Spearman correlation coefficient and the $p$-value

10. Number of significant differences indicated by the Kruskal-Wallace and Kuiper statistical tests for comparisons between sample discharge and daily mean discharge data distribution for each constituent at 47 Ambient Water-Quality Monitoring Network sites with continuous discharge data.

11. Sum of the number of significant differences indicated by the Kruskal-Wallace and Kuiper statistical tests for comparisons between sample discharge and daily mean discharge data distribution for each constituent at 47 Ambient Water-Quality Monitoring Network sites with continuous discharge data

12. Maximum and minimum sampled discharge at the Ambient Water-Quality Monitoring Network sites and the percentage of the daily mean discharge record that was greater than the maximum sampled discharge or was less than the minimum sampled discharge 
13. Aggregated number of significant differences, approximate percentage of significant differences, and site relative sensitivity to the simulated change in data collection frequency

14. Aggregated number of significant differences, approximate percentage of significant differences, and constituent relative sensitivity to the simulated change in data collection frequency.

15. Summary of reduced frequency trend analysis results for select physical properties and chemical constituents at sites in the Missouri Ambient Water-Quality Monitoring Network and other select sites, January 1993 through December 2017...

16. Comparison of the simulated reduced frequency trend results to the results obtained using the monthly data at select sites in the Ambient Water-Quality Monitoring Network in Missouri.....

17. Alternate discharge sites, regression models, and correlation coefficients for estimating continuous discharge at ungaged Ambient Water-Quality Monitoring Network sites.

18. Comparison of constituent data distributions for all possible pairs of sites grouped by class

19. Comparison of constituent data distributions for all possible pairs of sites on the Missouri and Mississippi Rivers.

20. Comparison of constituent data distributions for all possible pairs of sites grouped by 4-digit hydrologic unit code

21. Comparison of constituent data distributions for all possible pairs of sites grouped by 8-digit hydrologic unit code

22. Comparison of constituent data distributions for all possible pairs of sites for the land-use classes.

23. Comparison of constituent data distributions for sites in the basins that have a watershed indicator site identified.

\section{Conversion Factors}

U.S. customary units to International System of Units

\begin{tabular}{lll}
\hline \multicolumn{1}{c}{ Multiply } & By & \multicolumn{1}{c}{ To obtain } \\
\hline foot (ft) & Length & \\
inch (in.) & 0.3048 & meter $(\mathrm{m})$ \\
mile (mi) & 2.54 & centimeter $(\mathrm{cm})$ \\
\hline & 1.609 & kilometer $(\mathrm{km})$ \\
\hline square mile $\left(\mathrm{mi}^{2}\right)$ & Area & \\
\hline & 2.590 & square kilometer $\left(\mathrm{km}^{2}\right)$ \\
cubic foot per second $(\mathrm{ft} / \mathrm{s})$ & Flow rate & \\
inch per year $(\mathrm{in} / \mathrm{yr})$ & 0.02832 & cubic meter per second $(\mathrm{m} / \mathrm{s})$ \\
\hline
\end{tabular}

Temperature in degrees Celsius $\left({ }^{\circ} \mathrm{C}\right)$ may be converted to degrees Fahrenheit $\left({ }^{\circ} \mathrm{F}\right)$ as follows:

$$
{ }^{\circ} \mathrm{F}=\left(1.8 \times{ }^{\circ} \mathrm{C}\right)+32 .
$$

Temperature in degrees Fahrenheit $\left({ }^{\circ} \mathrm{F}\right)$ may be converted to degrees Celsius $\left({ }^{\circ} \mathrm{C}\right)$ as follows:

$$
{ }^{\circ} \mathrm{C}=\left({ }^{\circ} \mathrm{F}-32\right) / 1.8 \text {. }
$$




\section{Datum}

Horizontal coordinate information is referenced to North American Datum of 1983 (NAD 83).

\section{Supplemental Information}

Specific conductance is given in microsiemens per centimeter at 25 degrees Celsius $(\mu \mathrm{S} / \mathrm{cm}$ at $\left.25^{\circ} \mathrm{C}\right)$.

Concentrations of chemical constituents in water are given in either milligrams per liter (mg/L) or micrograms per liter $(\mu \mathrm{g} / \mathrm{L})$. 


\section{Abbreviations}

\begin{tabular}{|c|c|}
\hline AWOMN & Ambient Water-Quality Monitoring Network \\
\hline CFU/100 mL & colony forming unit per 100 milliliters \\
\hline $\mathrm{Cl}$ & dissolved chloride \\
\hline CWA & Clean Water Act \\
\hline DAR & drainage area ratio \\
\hline DO & dissolved oxygen \\
\hline $\mathrm{DP}$ & dissolved phosphorus as phosphorus \\
\hline $\mathrm{DPb}$ & dissolved lead \\
\hline DTPL & Dissected Till Plains \\
\hline $\mathrm{DZn}$ & dissolved zinc \\
\hline EC & Escherichia coli \\
\hline EGRET & Exploration and Graphics for River Trends \\
\hline FC & fecal coliform \\
\hline HUC & hydrologic unit code \\
\hline IQR & interquartile range \\
\hline KS & Kolmogorov-Smirnov \\
\hline KS2 & two-sample Kolmogorov-Smirnov \\
\hline KW & Kruskal-Wallis \\
\hline LOWESS & locally weighted scatterplot smoothing \\
\hline LRL & laboratory reporting level \\
\hline LT-MDL & long-term method detection limit \\
\hline MDL & method detection level \\
\hline MDNR & Missouri Department of Natural Resources \\
\hline MRL & method reporting level \\
\hline N03 & nitrate plus nitrite as nitrogen \\
\hline NWIS & National Water Information System \\
\hline NWQL & National Water Quality Laboratory \\
\hline NWOP & National Water-Quality Program \\
\hline OSPL & Osage Plains \\
\hline OZPLSA & Ozark Plateaus Salem Plateau \\
\hline OZPLSP & Ozark Plateaus Springfield Plateau \\
\hline QC & quality control \\
\hline$r^{2}$ & correlation coefficient \\
\hline SC & specific conductance \\
\hline
\end{tabular}


SCR

TMDL

TP

$\mathrm{TPb}$

TSS

TZn

USGS

WBC-A

WBC-B

WT secondary contact recreation

total maximum daily load

total phosphorus as phosphorus

total recoverable lead

total suspended solids

total recoverable zinc

U.S. Geological Survey

whole body contact class $\mathrm{A}$

whole body contact class B

water temperature 



\title{
General Water-Quality Conditions, Long-Term Trends, and Network Analysis at Selected Sites within the Ambient Water-Quality Monitoring Network in Missouri, Water Years 1993-2017
}

\author{
By Joseph M. Richards and Miya N. Barr
}

\section{Abstract}

The U.S. Geological Survey, in cooperation with the Missouri Department of Natural Resources, collects data pertaining to the surface-water resources of Missouri. Established in 1964, the Ambient Water-Quality Monitoring Network (AWQMN) consisted of 69 sites in 2017. Two additional sites from the National Water-Quality Program are included with the AWQMN sites for the analyses in this report. The sites are sampled typically from 2 to 12 times per year for physical properties, total suspended solids, nutrients, fecal indicator bacteria, and trace elements.

The period of analysis for this study was from 1993 through 2017 and data analysis included 71 sites and 15 waterquality constituents plus discharge. Data analysis involved retrieving the data, conditioning the data for analysis, analyzing the data for trends, and analyzing the monitoring network to determine if potential data gaps or data redundancies exist in the network. Results from these analyses can be used to help manage the monitoring network into the future.

Water-quality data were analyzed using several software packages to provide graphical and statistical information for interpretation of trends in the data at selected sites. Discharge data at selected sites were analyzed to determine the general trends during the analysis period and how the water-quality samples represented the range of daily mean discharges at each site. Water-quality data also were analyzed at selected sites to determine the relative sensitivity of selected sites and constituents to changes in data collection frequency. Trend analysis at selected sites using a simulated reduction in sampling frequency was completed to compare to trends obtained using monthly data to determine the potential degradation in the ability of determining trends from a reduced sampling frequency. The viability of using estimated discharge to evaluate long-term trends for sites with no continuous discharge was investigated. Data from sites were statistically compared in groups to determine the relative similarity (or difference) between sites for each water-quality constituent to identify potentially redundant sites in the monitoring network.
Discharge-weighted long-term trends during 1993 through 2017 were analyzed for 15 water-quality constituents at 58 sites and results indicated there were significant singleor two-period trends in about 17 percent of the analyses. Some trends indicated improvement and some trends indicated deterioration of the general water quality at some sites in the AWQMN. No trend was indicated in about 31 percent of the analyses. The constituents $\mathrm{pH}$, specific conductance, and total phosphorus showed the most frequent significant trends, and each of the 15 constituents examined had a significant trend at one or more sites. A total of 42 sites indicated at least 1 constituent with a significant single- or two-period trend, and 10 sites indicated 6 or more significant trends.

Potential data gaps identified for computing dischargeweighted long-term trends in the monitoring network included the lack of collection of continuous discharge at 23 sites, insufficient sampling frequency for some constituents (dissolved chloride and total and dissolved lead and zinc) at some sites, insufficient temporal sample distribution (lack of at least one sample in each season per year) at some sites, and insufficient sampling frequency for some highly censored constituents (nutrients and total and dissolved lead and zinc) at some sites. Potential data gaps based on site spatial distribution were identified in 7 basins greater than 800 square miles.

Potential site redundancies were identified in 4 basins that had an area greater than 500 square miles with a site density greater than 2 sites per 1,000 square miles. Potential site redundancies also were identified for nine site pairs by observing statistical similarities in the constituent data distributions. Sampling frequency was investigated to determine if reducing the sampling frequency of select constituents could provide a statistically similar data distribution. At 28 of 71 sites, 11 constituents had sufficient data collection frequency (approximately monthly) to allow for the creation of simulated datasets of various reduced data collection frequency. For the selected monitoring network sites analyzed, the data distribution of a simulated sampling frequency of four times per year or greater, roughly evenly distributed over the year, was not significantly different than the data distribution of the original monthly sampling frequency. Sites analyzed using varying 
simulated sampling frequencies tended to be more sensitive to sampling frequency changes if they were in basins classified as large or very large size and tended to be least sensitive in basins classified as small and medium size in the Ozark Plateaus Province. Simulated reduced frequency sampling analysis indicated that the constituents and measurements most sensitive to changes in sampling frequencies were water temperature, dissolved oxygen, discharge, and dissolved nitrate, and least sensitive were $\mathrm{pH}$, total suspended solids, dissolved phosphorus, and total phosphorus. Discharge-weighted longterm trend analysis was repeated at 22 sites for 11 constituents using a simulated quarterly sampling frequency, and matched about 46 percent of the significant single-period trends identified using monthly data and about 65 percent of the analyses that indicated no trend using the monthly data.

\section{Introduction}

The U.S. Geological Survey (USGS), in cooperation with the Missouri Department of Natural Resources (MDNR), collects data pertaining to the surface-water resources of Missouri. These data are collected as part of the Missouri Ambient Water-Quality Monitoring Network (AWQMN) and are stored and maintained by the USGS National Water Information System (NWIS; U.S. Geological Survey, 2020) database. These data constitute a valuable source of reliable, impartial, and timely information for developing an improved understanding of the water resources of the State.

The MDNR is responsible for the implementation of the Federal Clean Water Act (CWA) in Missouri. Section 305(b) of the CWA requires that each State develop a water-quality monitoring program and periodically report the status of its water quality (U.S. Environmental Protection Agency, 1997). Water-quality status is described in terms of the suitability of the water for various uses, such as drinking water, fishing, swimming, and aquatic life; these uses are formally defined as "designated uses" in State and Federal Regulations. Section 303(d) of the CWA requires that certain waters that do not meet applicable water-quality standards be identified and total maximum daily loads (TMDLs) be determined for these waters (U.S. Environmental Protection Agency, 1997). TMDLs establish the maximum amount of a contaminant that a water body can assimilate and still meet the water-quality standards. Separate TMDLs address each contaminant for each water body.

Missouri has an area of about 69,700 square miles $\left(\mathrm{mi}^{2}\right.$; State of Missouri, undated) with 115,772 miles (mi) of classified streams that support a variety of uses including wildlife, recreation, agriculture, industry, transportation, and public utilities (Missouri Department of Natural Resources, 2018a). Missouri Department of Natural Resources (2018a) reports that $5,676 \mathrm{mi}$ of streams are adversely affected by various physical changes or chemical contaminants that impair these streams for at least one of their designated uses.
Public agencies that protect and manage water resources have a critical need for information gained through waterquality monitoring. Information from water-quality monitoring is needed to assess the existing conditions of water resources; to design preservation, management, and remediation programs; and to evaluate the effectiveness of such programs (Intergovernmental Task Force on Monitoring Water Quality, 1995). Monitoring also is needed to document compliance with local, State, and Federal regulations and permits. In addition, the results of water-quality monitoring are needed to detect and define trends in water quality and to identify emerging water-quality concerns.

\section{The Ambient Water-Quality Monitoring Network}

The AWQMN was established in 1964 with 18 surfacewater quality sites and increased to 41 sites by 1986 . During the early 1990s, the network decreased to only 5 sites because of State funding limitations, but by 1994, the AWQMN increased to 39 sites. By 2017, the program consisted of 69 AWQMN sites. Two additional sites from the National Water-Quality Program (NWQP) are included in the analyses in this report, and collectively the 71 sites in the AWQMN and NWQP will be hereafter referred to as "the AWQMN" in this report.

The objectives of the AWQMN are to (1) obtain information on the quality and quantity of surface water within the State; (2) provide a historical water-quality database that can be used by State planning and management agencies to make informed decisions about anthropogenic effects on the surface waters of the State; and (3) provide consistent datacollection methods, laboratory analysis, and data reporting (Otero-Benítez and Davis, 2009a, 2009b). Additionally, for some sites, water-quality trends in some constituents were of concern to the State.

\section{Purpose and Scope}

The purpose of this report is to describe the water-quality assessment, including general water-quality conditions and long-term trends from water years 1993 through 2017, at 71 AWQMN sites (fig. 1, table 1) that meet the assessment criteria. A water year is defined as the period October 1 through September 30 and is designated by the calendar year in which it ends. The AWQMN water-quality sample data were used to evaluate the robustness of the network in terms of being able to describe the water-quality trends and conditions in Missouri. A network analysis of the current (2020) AWQMN was completed to determine the efficiency of the current sampling design and the efficacy of the current sampling design to determine trends and loads.

The 15 constituents used in this report are physical properties (water temperature [WT], dissolved oxygen (DO), specific conductance $[\mathrm{SC}]$, and $\mathrm{pH}$ ), total suspended solids (TSS), nutrients (nitrate plus nitrite as nitrogen [NO3], dissolved 


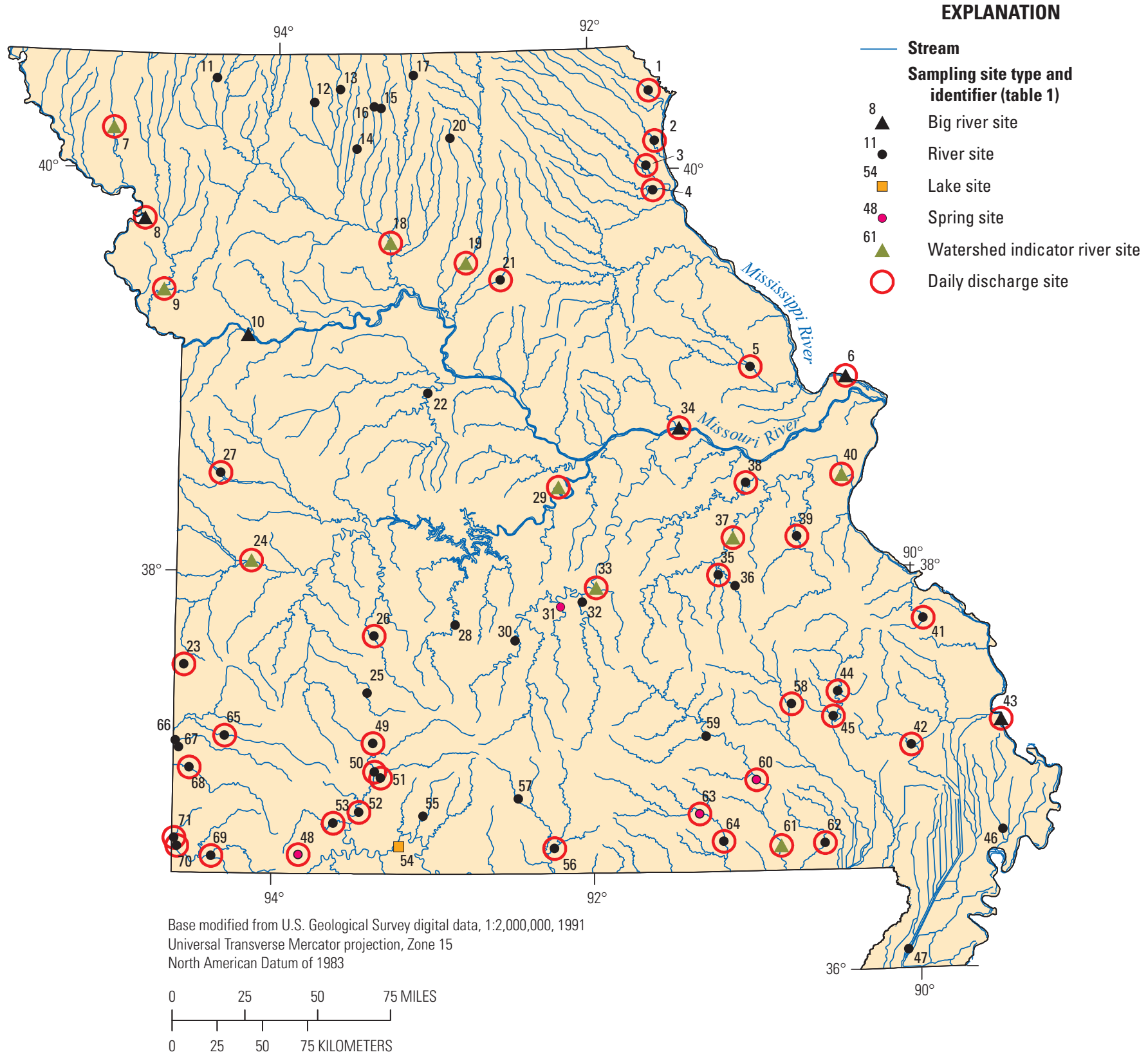

Figure 1. Location of Ambient Water-Quality Monitoring Network sites in Missouri.

phosphorus as phosphorus [DP] and total phosphorus as phosphorus [TP]), fecal indicator bacteria (Escherichia coli [EC] and fecal coliform [FC]), dissolved chloride [Cl], and trace elements (dissolved lead [DPb], dissolved zinc [DZn], total recoverable lead $[\mathrm{TPb}]$, and total recoverable zinc [TZn]). Discharge at the time of sampling was included as an additional component in many of the analyses in this report. Other constituents also analyzed during the study period but not used for analysis in this report include other major ions, other trace elements, and pesticides at selected sites.

\section{Description of Study Area}

Water-quality constituent concentrations are closely connected to the physiography, land use, and climate conditions in the drainage basin upstream from the sampling site. A brief description of the physiography, land use, and climate conditions, as well as a summary of the hydrologic conditions in Missouri, are presented here to provide context for the discussion of the trends and network analysis of the AWQMN during the 1993 to 2017 data analysis period. 


\section{Physiography}

Missouri has three major physiographic provinces within its State boundaries - Central Lowland, Ozark Plateaus, and Coastal Plain (Fenneman, 1938; Collier, 1955; Missouri Department of Natural Resources, 2018b; fig. 2). The physiographic provinces are further divided into sections depending on the underlying geology. The Central Lowland Province occupies a large amount of area in the central United States and within Missouri and is divided into two different sections: the Dissected Till Plains (DTPL) section is mostly north of the Missouri River and the Osage Plains (OSPL) section is in west-central Missouri (fig. 2). The DTPL section was formerly glaciated, whereas the OSPL section was not (Fenneman, 1938; Collier, 1955; Missouri Department of Natural Resources, 2018b). The DTPL and the OSPL sections are underlain mostly by Pennsylvanian-age soft shales with interbedded sandstones and limestones (Adamski and others, 1995; Starbuck, 2017). The DTPL section is a loess-covered, mostly flat plain formed from sediments deposited from melting glaciers (Fenneman, 1938; Collier, 1955). The topography typically is gently rolling hills with some steeper slopes near streams. Land slopes in the Central Lowland Province of Missouri are generally from 3 to 10 percent with the higher slopes generally nearer streams; streams in this province typically have a lower gradient than those in the Ozark Plateaus Province (Collier, 1955). Springs in the DTPL and OSPL sections are smaller than those in the Ozark Plateaus Province and do not contribute to overall discharge (Vineyard and Feder, 1974). Relative to the Ozark Plateaus Province, the modest land slope, generally low relief, and productive soils make this province well suited to agriculture.

The Ozark Plateaus Province is divided into two sections known as the Salem Plateau and the Springfield Plateau (Fenneman, 1938; Missouri Department of Natural Resources, 2018b; fig. 2). The bedrock geology of the Salem Plateau is predominantly Cambrian- and Ordovician-age dolomitic carbonate rocks, whereas the Springfield Plateau is mostly Mississippian-age limestone and chert (Starbuck, 2017). Some of the largest local relief and greatest land slopes are present in an area of Precambrian-age igneous rocks that crop out in an area known as the St. Francois Mountains in the Salem Plateau section of southeastern Missouri (Collier, 1955; Starbuck, 2017). The Salem Plateau is densely wooded, and has steep, rugged topography with narrow valleys, dendritic drainages, and steep main channel gradients. The Springfield Plateau has less relief than the Salem Plateau, with gently rolling hills that generally are a mixture of woods and pasturelands. Sinkholes, caves, losing streams, and springs, features common in karst terrane, are widespread in the Ozark Plateaus Province, but are more prevalent and larger in the Salem Plateau (Vineyard and Feder, 1974). Compared to the other two provinces, the land surface of the Ozark Plateaus Province is generally more rugged, and the soils are less productive, causing it to be less adapted to agriculture (Collier, 1955).
The Coastal Plain Province is in the area commonly referred to as the "bootheel" of Missouri and is known as the Mississippi Alluvial Plain (fig. 2). The surficial geology of the Coastal Plain Province is predominantly Quaternaryage unconsolidated sand and clay that is largely deposited in a riverine environment (Starbuck, 2017). This province is characterized by low relief and a very gentle land slope, typically less than 3 percent, in the delta and bottomlands of the Mississippi River and its tributaries (Fenneman, 1938; Collier, 1955). Gentle slope and productive soils make this province well adapted to agriculture.

\section{Land Use}

Land use in Missouri in 2016 is about 51.8 percent agricultural (30.9 percent pasture/grassland and 20.9 percent cultivated crops) and 37.9 percent forested (Multi-Resolution Land Characteristics Consortium, 2020; fig. 3). Combined, agricultural and forested land represent about 89.7 percent of the area of the State. The balance of the State land use consists of about 5.7 percent urban, 2.0 percent wetlands, 1.5 percent open water, and 1 percent barren land. In the Central Lowland Province, land use is primarily agricultural and includes cultivated crops such as corn, soybeans, and wheat, and livestock such as cattle, hogs, and poultry. Land use in the Ozark Plateaus Province mainly is agricultural (cattle and poultry production) in the Springfield Plateau section (fig. 2) and mainly is forested with some agriculture in the Salem Plateau section (fig. 2). Agricultural land use in the Coastal Plain Province mostly is cultivated crops, such as cotton, rice, and sorghum. Mining of various mineral resources, primarily ore minerals for lead, zinc, barium, and iron, began in the 1700s in southeast Missouri (Mugel, 2017). Mining in this area continues today (2020). Mining, primarily for ore minerals of lead and zinc, in southwest Missouri became commercially important in the early 1850 s, peaked in the 1920 s, and declined in the region in the mid-1900s (Smith, 2016). Most of the commercially successful mining in Missouri took place south of the Missouri River in the Ozark Plateaus Province near the towns of Joplin in southwest Missouri and Potosi, Park Hills, and Viburnum in southeast Missouri.

The 2019 estimated population of Missouri is 6.14 million people (U.S. Census Bureau, 2020). Three major urban areas are in Missouri-Kansas City, St. Louis, and Springfield (fig. 3). Land use that is classified as urban (paved areas such as roads and parking lots, areas of suburban housing, city downtown areas, and similar urban features) makes up about 5.7 percent of the State. Urban areas, even in small amounts relative to the drainage basin size, can have a substantial effect on the water quality of a stream. The 2016 land-use percentages of the drainage basins for the AWQMN sites are listed in table 2.

The data analyzed for these land-use changes (table 2) made no distinction between the direction of change. For example, a 10-percent change between cultivated crops and pasture or grassland (hereafter referred to as "pasture") means 


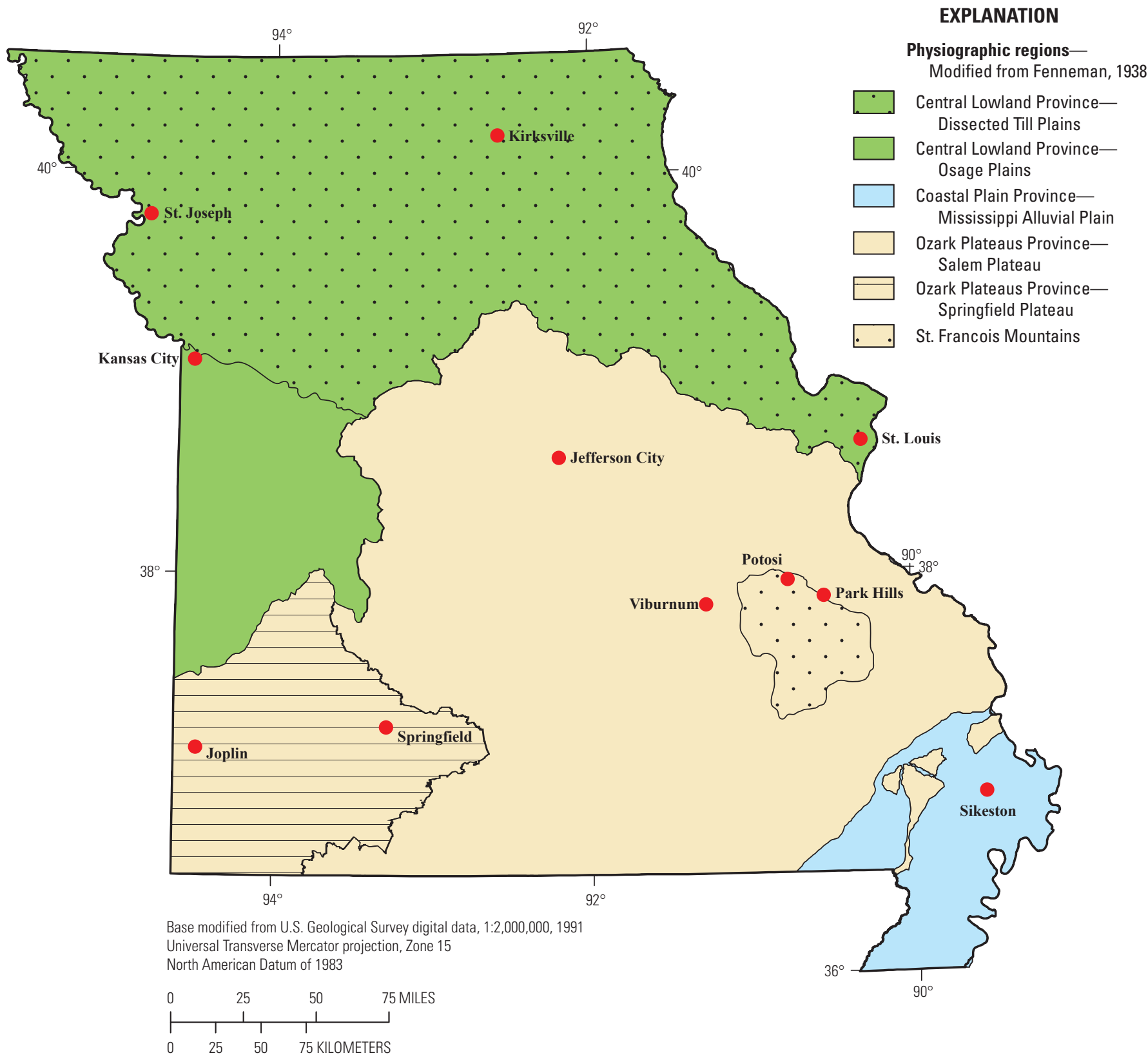

Figure 2. Physiographic regions of Missouri.

that 10 percent of the land use classified as cultivated crops changed to pasture, or vice versa. For example, some (6 percent) could have changed from pasture to cultivated crops, and some (4 percent) could have changed from cultivated crops to pasture, but the total amount of change between the two land-use classes was 10 percent. Land-use changes combined with the water-quality trend analyses may provide insight into changes in water quality.

Changes in land use between 2001 and 2016 in the AWQMN basins were generally small (table 2 ), averaging about 0.54 percent and ranging from about 0 (at site 23 ) to
13.2 percent (at site 11, change between cultivated crops and pasture). It is suspected that some of the changes can be attributed to changes in the way land-use data were acquired, processed, and classified over time. The dominant changes in land use in the AWQMN basins were between cultivated crops and pasture, between any land-use category and forest, and between any land-use category and urban. These three landuse changes accounted for a mean of about 79.8 percent of the total change in land use in the AWQMN basins between 2001 and 2016, whereas the mean area that did not change class between 2001 and 2016 was about 94.6 percent. 


\section{Climate}

Missouri has a temperate climate with a long-term (1895 through 2018) mean annual temperature of 54.6 degrees Fahrenheit $\left({ }^{\circ} \mathrm{F}\right)$, and mean annual precipitation of 40.9 inches per year (in/yr) across the State (Missouri Climate Center, 2019). The climate of Missouri follows a gradient diagonally across the State from northwest to southeast, with lower temperatures in the northwest and larger annual precipitation in the southeast (Barr and Davis, 2010).

Temperature and rainfall departures from normal annual precipitation from 1895 to 2018 were analyzed by the Missouri Climate Center (2019; fig. 4). The period from 1993 to 2017 was wetter and warmer than the long-term mean for Missouri. The decade of the 1990s was the wettest on record for the State, but there were regional summer droughts in 1991 and 1999, as well as in the following decade in 2002-03 and 2005-06 (Decker and Guinan, 2016). A record wet period affected Missouri from 2008 to 2010 followed by regional drought conditions in the fall of 2010 and a statewide extreme drought in 2012 (Decker and Guinan, 2016).

For the purposes of this report, the seasons are defined as winter (December to February), spring (March to May), summer (June to August), and fall (September to November). Typically, most rainfall in Missouri occurs from mid-spring through mid-summer. Measurable precipitation occurs approximately 100 days a year, with nearly one-half of the days as thunderstorms. Snowfall varies from 18 to 24 inches (in.) north of the Missouri River to a mean of 8 to 12 in. in the southern one-half of the State (Barr and Davis, 2010).

Winters in Missouri can be variable in terms of temperature and duration, and the long-term (1895 through 2018) mean winter temperature is slightly above freezing at $32.1^{\circ} \mathrm{F}$ (Missouri Climate Center, 2019). Winter also tends to be the driest season but typically yields 6.6 in. of precipitation. The long-term records indicate that spring is generally the second wettest season of the year, with a mean precipitation of $12 \mathrm{in}$. and a long-term mean temperature of about $54.2^{\circ} \mathrm{F}$ (Missouri Climate Center, 2019). Summer is typically very humid and is the wettest and hottest season of the year, with a long-term mean precipitation of $12.2 \mathrm{in}$. and a mean temperature of $75.6^{\circ} \mathrm{F}$ (Missouri Climate Center, 2019). The extreme highs for the year often are in July or August. Fall has a long-term mean precipitation of about $10.2 \mathrm{in}$. and a mean temperature of $56.4^{\circ} \mathrm{F}$ (Missouri Climate Center, 2019).

\section{Summary of Hydrologic Conditions}

Surface-water discharge conditions in Missouri vary seasonally and tend to reflect precipitation patterns. Streamgages are collocated with or near 47 AWQMN sites distributed across the State, and continuous discharge data are available for those sites (fig. 1; table 1). Compared to the long-term mean, precipitation patterns indicate a relatively wet period occurred from 1993 through 2017 (fig. 4). The decade of the 1990s was exceptionally wet (Decker and Guinan, 2016).
Although the 2000s through the 2010s were mostly wetter than the long-term mean, they were somewhat drier than the 1990s. Beginning in the mid-2010s, several years of greater than mean precipitation led to regional flooding in many parts of the State and set record peak discharges from water years 2015 to 2017 at 40 of 123 Missouri streamgages with 10 or more years of record (U.S. Geological Survey, 2019a). Computed runoff data for Missouri, obtained from the USGS WaterWatch web page (U.S. Geological Survey, 2019a), were ranked for water years 1993 through 2017 and indicated that 6 of the top 10 values during that period were from 2008 to 2017 and 4 of the top 10 were from 1993 to 1998.

These general precipitation and runoff observations are reflected in the plots of annual and seasonal discharge yield for 7-day minimum, mean, and 1-day high discharge for the AWQMN sites produced in the USGS hydrologic data analysis package EGRET (Exploration and Graphics for River Trends; Hirsch and De Cicco, 2015). An example plot of annual and seasonal discharge yield for site 38 at the Bourbeuse River above Union, Missouri, is shown in figure 5. Plots of annual and seasonal discharge yield for the sites with continuous discharge data in the AWQMN can be obtained from a USGS data release (Richards and Barr, 2021). Yield, expressed in units of millimeters of runoff per day, normalizes the discharge to the drainage area of the basin and is used so that values can be compared between sites. At the three spring sites that had continuous discharge data during the analysis period (sites 48 , 60 , and 63 ; table 1), a contributing drainage area was assumed. The contributing drainage areas for site $60\left(430 \mathrm{mi}^{2}\right)$ and $63\left(348 \mathrm{mi}^{2}\right)$ were obtained from dye trace analysis (Mugel and others, 2009). For site 48, the contributing drainage area $\left(67 \mathrm{mi}^{2}\right)$ was estimated from the period of record daily mean discharge at the site using a relation developed by Miller and Vandike (1997). Yield values for all sites with continuous discharge data were determined by dividing the annual mean discharge (or seasonal mean discharge) by the basin area and plotted. A locally weighted scatterplot smoothing (LOWESS) line was computed for the scatterplot yield data in EGRET to provide a graphical indication of the general trend of the data (Hirsch and De Cicco, 2015).

The LOWESS line for the annual mean discharge yield indicates no trend or a slight downward trend at about onehalf of the AWQMN sites, and most of these sites are in the Ozark Plateaus Province (Richards and Barr, 2021). Sites with a shorter period of discharge record (typically early to mid-2000s to 2017) tend to show an increase in annual mean discharge yield, which is probably the result of comparably higher precipitation toward the end of this period. Sites with discharge record from water years 1993 to 2017 often show a subtle concave upward LOWESS line, indicating the correspondence to the relatively wet decades of the 1990s and 2010s, and the comparably drier decade of the 2000s (fig. 5).

The discharge at some sites is affected by effluent releases and may not exhibit discharge patterns typical of streams where the discharge is determined primarily by precipitation and groundwater inputs. For example, site 49 (Wilson Creek 


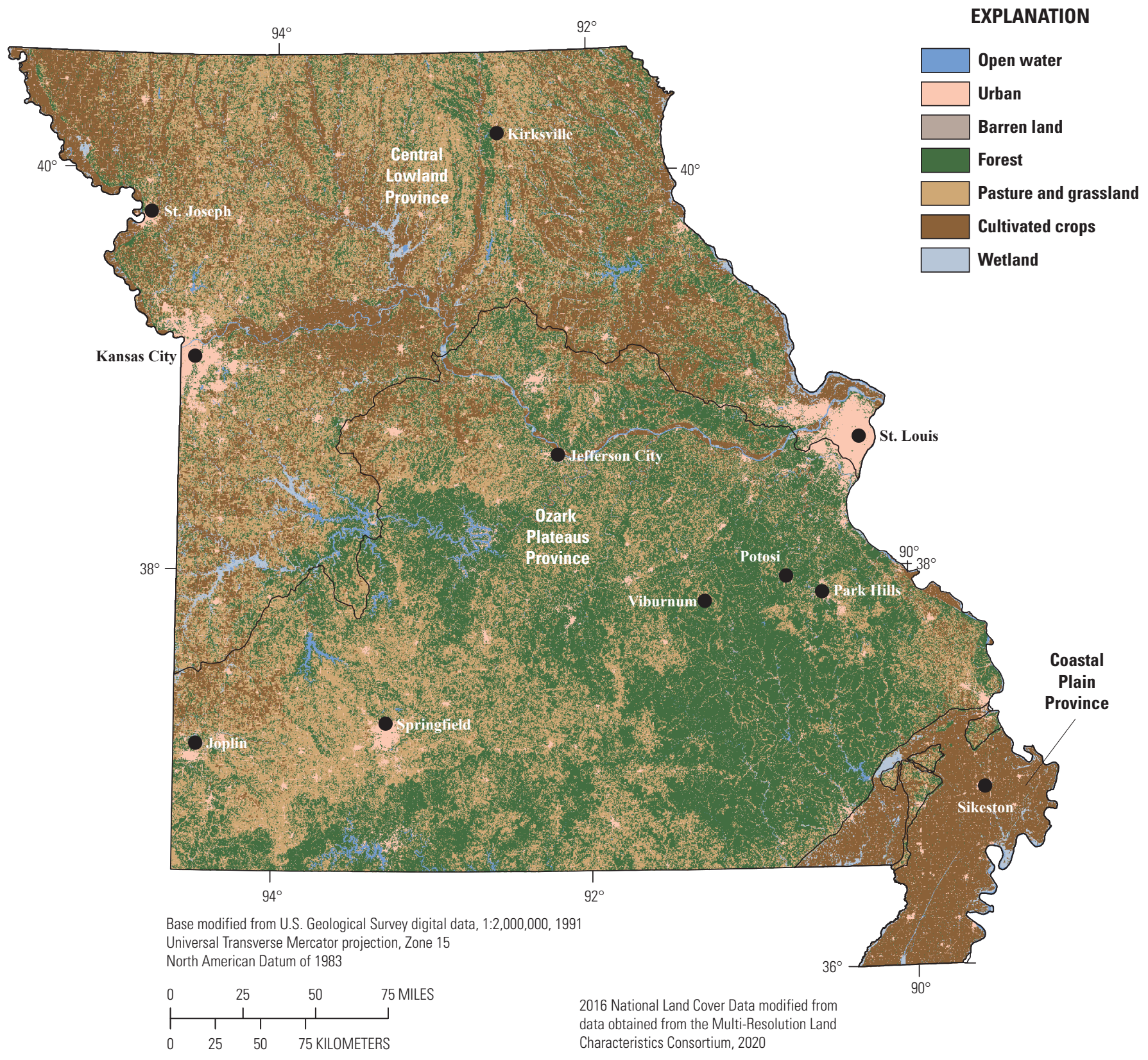

Figure 3. Land use in Missouri, 2016.

near Brookline, Missouri) is affected by effluent releases from the Springfield Southwest Wastewater Treatment Plant, particularly at low discharges. Mean annual discharge data for water years 1993 through 2017 for each site are shown in table 2. Discharge at any site downstream from a reservoir could be affected by releases from the reservoir and may not exhibit discharge patterns typical of streams where the discharge is determined primarily by precipitation and groundwater inputs.
For example, locations like site 29 (Osage River below St. Thomas, Missouri) can be affected by upstream reservoir releases, and locations like sites 8, 10, and 34 (Missouri River at St. Joseph, Missouri; Missouri River at Sibley, Missouri; and Missouri River at Hermann, Missouri, respectively) on the Missouri River can be affected by reservoir releases from Gavins Point Dam (not shown on figures) hundreds of river miles upstream. 


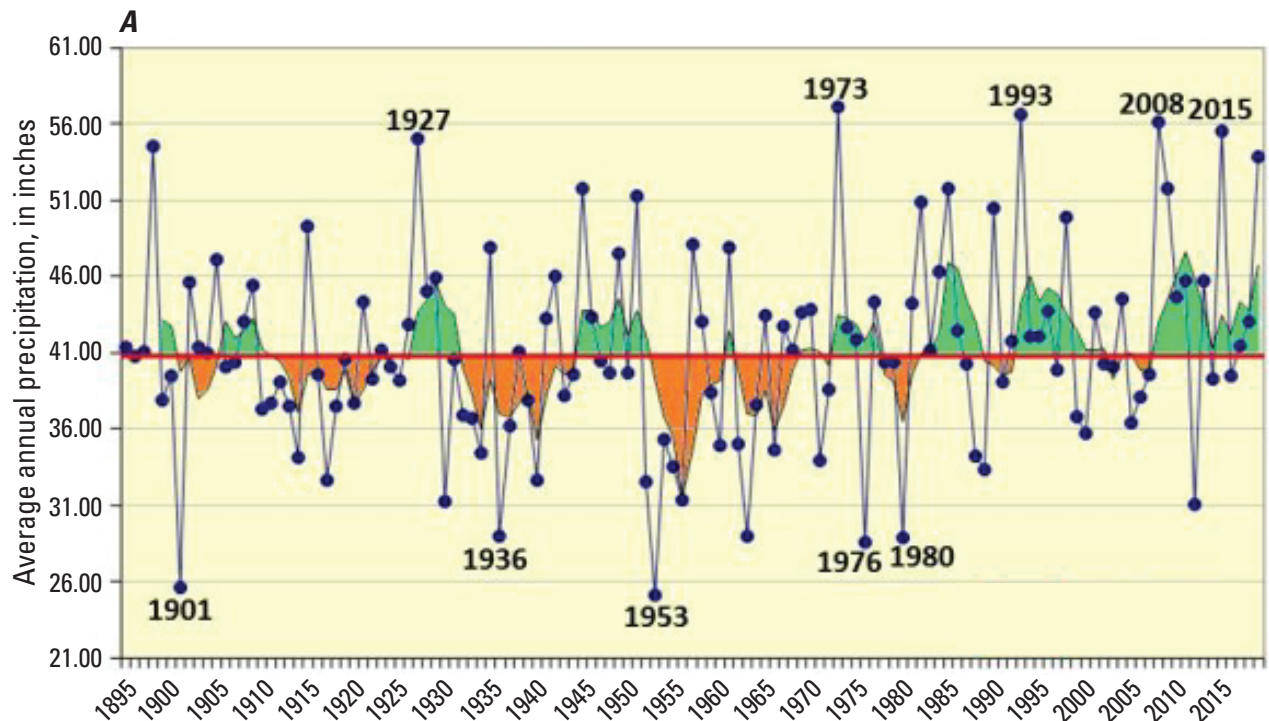

\section{EXPLANATION}

\section{Wet period}

Dry period

Long-term average-

40.86 inches

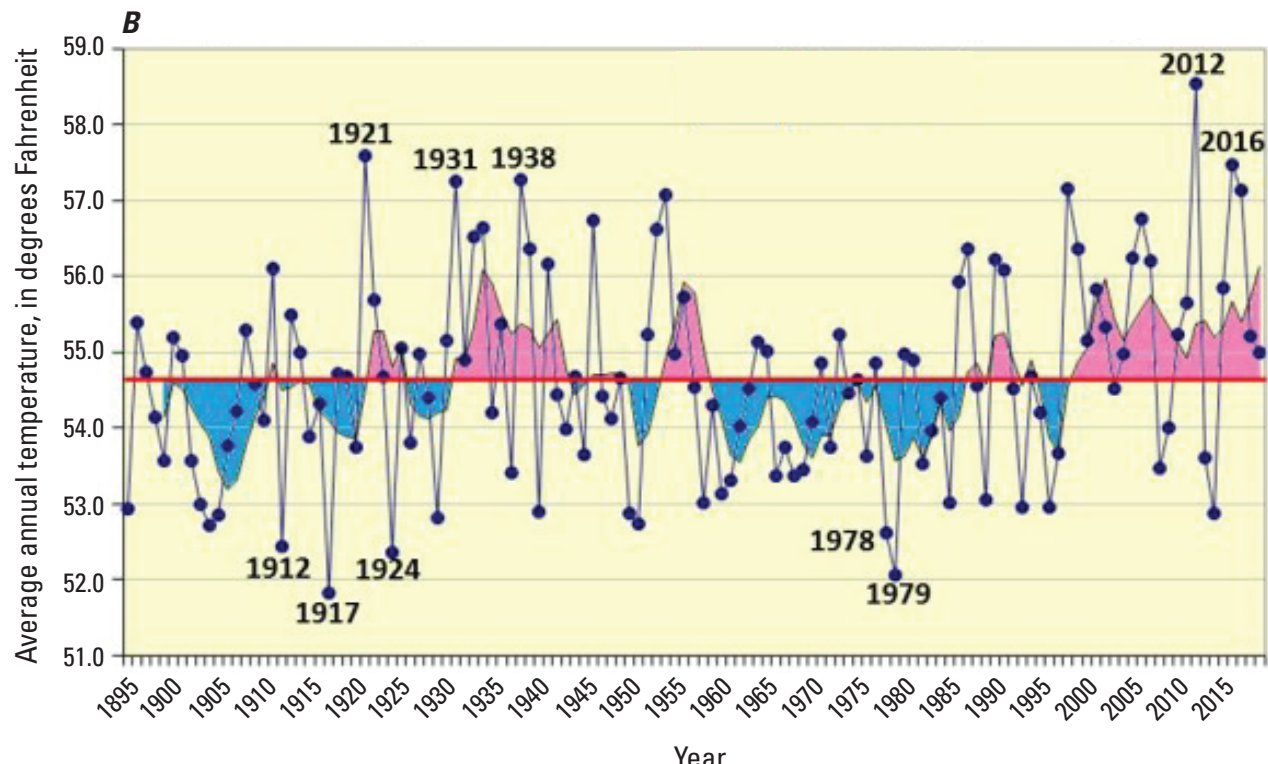

\section{EXPLANATION}

\section{Warm period}

Cool period

Long-term average-

54.6 degrees Fahrenheit

Missouri Climate Center, 2019

Figure 4. Departure from mean precipitation and temperature in Missouri 1895-2018 from the Missouri Climate Center (2019). $A$, Precipitation. $B$, Temperature. 

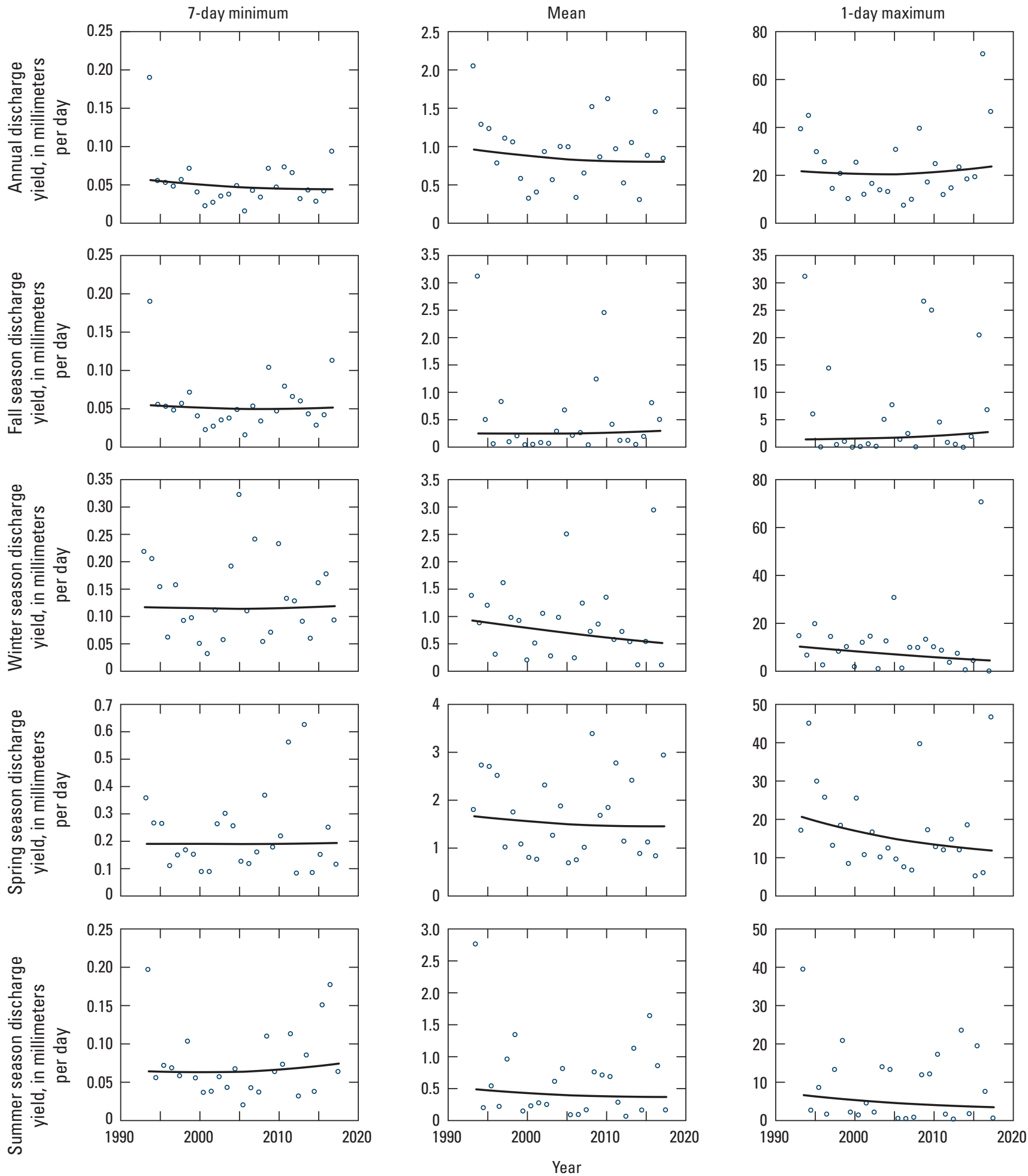

\section{EXPLANATION}

Figure 5. Annual and seasonal discharge yield for 7-day minimum, mean, and 1-day maximum for water years 1993 through 2017 at site 38 (U.S. Geological Survey streamgage 07016400, Bourbeuse River above Union, Missouri; fig. 1; table 1), produced by the EGRET software (Hirsch and De Cicco, 2015). Months for Fall are September, October, and November; for Winter, December, January, and February; for Spring, March, April, and May; and for Summer, June, July, and August. 


\section{Methods}

Methods of site classification, water-sample and discharge data collection, data analysis of the results, and spatial data compilation are described in the following sections. Hereinafter, each site will be referred to as a site number (1 through 71; fig. 1; table 1).

\section{Description and Classification of Sites in the Sampling Network}

For the period of analysis from water year 1993 through 2017 , each of the 71 AWQMN sites had at least 8 years of water-quality data available, and the mean period of record for all sites was about 20.5 years. The sampling frequency at the AWQMN sites varied during the period of analysis. Sampling frequency within the AWQMN is determined by several factors, including the size of the drainage basin, effects from land use and human-influenced activity, history of the water chemistry, the need for data, the need to track temporal changes at some sites, and cost (Barr and Davis, 2010).

The Nation is divided and subdivided into successively smaller hydrologic units based on topographic surface features and identified by a unique hydrologic unit code (HUC; Seaber and others, 1987). There are 212 -digit HUC regions that cover the Nation and generally represent all or most of a major river system, such as the Missouri or Mississippi Rivers (Seaber and others, 1987). Parts of four 2-digit HUC regions intersect Missouri: the Upper Mississippi (07), Lower Mississippi (08), Missouri (10), and the Arkansas-White-Red (11). There are 222 4-digit HUC subregions that cover the Nation and generally represent large river systems with a mean basin area of about 30,000 $\mathrm{mi}^{2}$ (Seaber and others, 1987). Parts of 13 4-digit HUC subregions intersect Missouri (fig. 6), and nine 4-digit HUC subregions have at least one AWQMN sampling site (table 1). There are 2,150 8-digit HUC cataloging units that cover the Nation and generally represent a large river system with a mean basin area of about 3,000 $\mathrm{mi}^{2}$ (Seaber and others, 1987). A total of 67 8-digit HUC cataloging units intersect Missouri, and 43 of these cataloging units have at least one AWQMN sampling site and 15 have more than one site (tables 1 and 3). It is assumed that as the areal subdivisions become smaller, sites within the same subdivision would be more likely to exhibit similar discharge and water-quality characteristics than those from sites outside the subdivision. This is because the factors that affect changes in discharge and water quality are likely to be similar within the same subdivision. The site density and the rank of the site density for the 4- and 8-digit HUCs, expressed as the number of AWQMN sites per 1,000 $\mathrm{mi}^{2}$ of HUC area, in Missouri are shown in table 3 . The site density rank in table 3 is computed for the 4and 8-digit HUCs separately and is included to better indicate which HUCs have a higher or lower site density compared to the others in its 4- or 8-digit HUC.
Drainage basin areas ranged from 0 to $713,200 \mathrm{mi}^{2}$ for the 71 sites in the AWQMN (table 1). The mean drainage basin area of $61 \mathrm{AWQMN}$ sites was about 1,038 $\mathrm{mi}^{2}$. This mean does not include the basins for sites $6,8,10,34$, and 43 on the Missouri and Mississippi Rivers; sites 31, 48, 60, and 63 (springs); and site 54 (lake). Several basins of AWQMN sites sampled within Missouri cross state lines into Arkansas, Kansas, and Iowa (fig. 6). The collective basin area (excluding sites $6,8,10,34$, and 43 on the Missouri and Mississippi Rivers) of the sites sampled represents about 48,900 $\mathrm{mi}^{2}$. The area of the basins within Missouri only is about 39,300 $\mathrm{mi}^{2}$ and represents about 56 percent of the area of the State.

Sites were categorized by drainage basin size from small to very large (table 1) for analysis. Basins classified as small had drainage areas less than $100 \mathrm{mi}^{2}$ (15 sites), basins classified as medium had drainage areas greater than $100 \mathrm{mi}^{2}$ and less than $500 \mathrm{mi}^{2}$ (28 sites), basins classified as large had drainage areas greater than $500 \mathrm{mi}^{2}$ and less than 5,000 $\mathrm{mi}^{2}$ (20 sites), and basins classified as very large had drainage areas greater than $5,000 \mathrm{mi}^{2}$ (8 sites, table 1).

In previous reports (Barr and Davis, 2010; Barr, 2010, 2011, 2013, 2014, 2015; Barr and Schneider, 2014; Barr and Heimann, 2016; Barr and Bartels, 2018, 2019), AWQMN sites have been classified based on several factors including the site type, dominant land use in the basin, past or present mining activity, and the physiographic province where the basin is located (table 1). Ten AWQMN sites (fig. 1, table 1) have been classified as watershed indicator sites (Barr and Davis, 2010; Barr, 2010, 2011, 2013, 2014, 2015; Barr and Schneider, 2014; Barr and Heimann, 2016; Barr and Bartels, 2018, 2019). Watershed indicator sites have a drainage area greater than $1,000 \mathrm{mi}^{2}$ and are usually the most downstream site in a particular drainage basin.

At the time of water-quality sample collection, discharge is either obtained from a streamgage, physically measured, or estimated. Continuous discharge data are collected at streamgages located at or near 47 of the 71 sites (fig. 1; table 1) and can be obtained from NWIS (U.S. Geological Survey, 2020) using the USGS station numbers in table 1. Five (sites 6, 38, 42, 48, and 65) of the 47 sites have discharge data that are obtained nearby, upstream, or downstream from the water-quality site. Site 6 uses discharge from streamgage 05587450 (not shown on figures). Site 38 uses discharge from streamgage 07016500 (not shown on figures). Site 42 uses discharge from streamgage 07021000 (not shown on figures). Site 48 uses discharge from streamgage 07050152 (not shown on figures). Site 65 uses discharge from streamgage 07185765 (not shown on figures). Two (sites 33 and 40) of the 47 sites have discharge data obtained nearby, but the data are adjusted, based on drainage area, to better estimate the discharge at the water-quality site. Discharge at site 33 is obtained by taking the discharge at streamgage 06933500 and subtracting 1.5 times the discharge at streamgage 06932000 (streamgage locations not shown on figures). Discharge at site 40 is obtained by adding 10 percent to the discharge at streamgage 07019000 (not shown on figures). Discharge is measured at the time of 


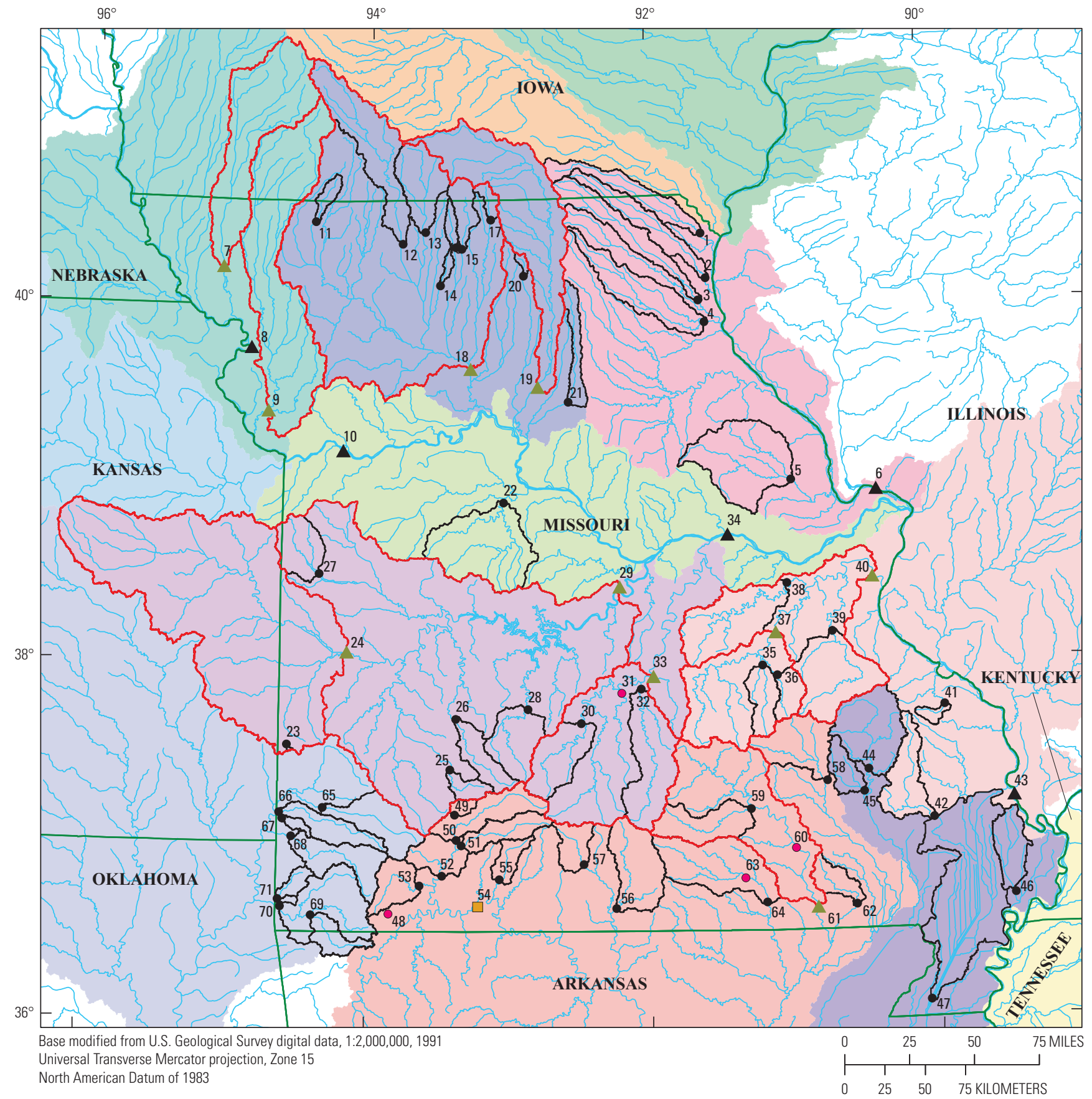

\section{EXPLANATION}

4-digit hydrologic unit subregions

\begin{tabular}{|l|l|l|}
\hline 0708 & 0801 & 1028 \\
\hline 0710 & 0802 & 1029 \\
\hline 0711 & 1024 & 1030 \\
\hline 0714 & 1027 & 1101 \\
\hline
\end{tabular}

Sampling site type and identifier

1107

54

${ }^{8}$ Big river site

- River site

$\square \quad$ Lake site

${ }^{48}$ - Spring site

${ }^{61}$ Watershed indicator river site

\section{Ambient water-quality site drainage} basin boundary

Watershed indicator site drainage basin boundary

Figure 6. Drainage basin boundaries of the Ambient Water-Quality Monitoring Network sites in relation to the 4-digit hydrologic unit code subregions in Missouri. 
Table 3. Drainage area, density of Ambient Water-Quality Monitoring Network sites, and rank of site density for the sites in each of the 4- and 8-digit hydrologic unit code areas.

[HUC, hydrologic unit code; $<$, less than]

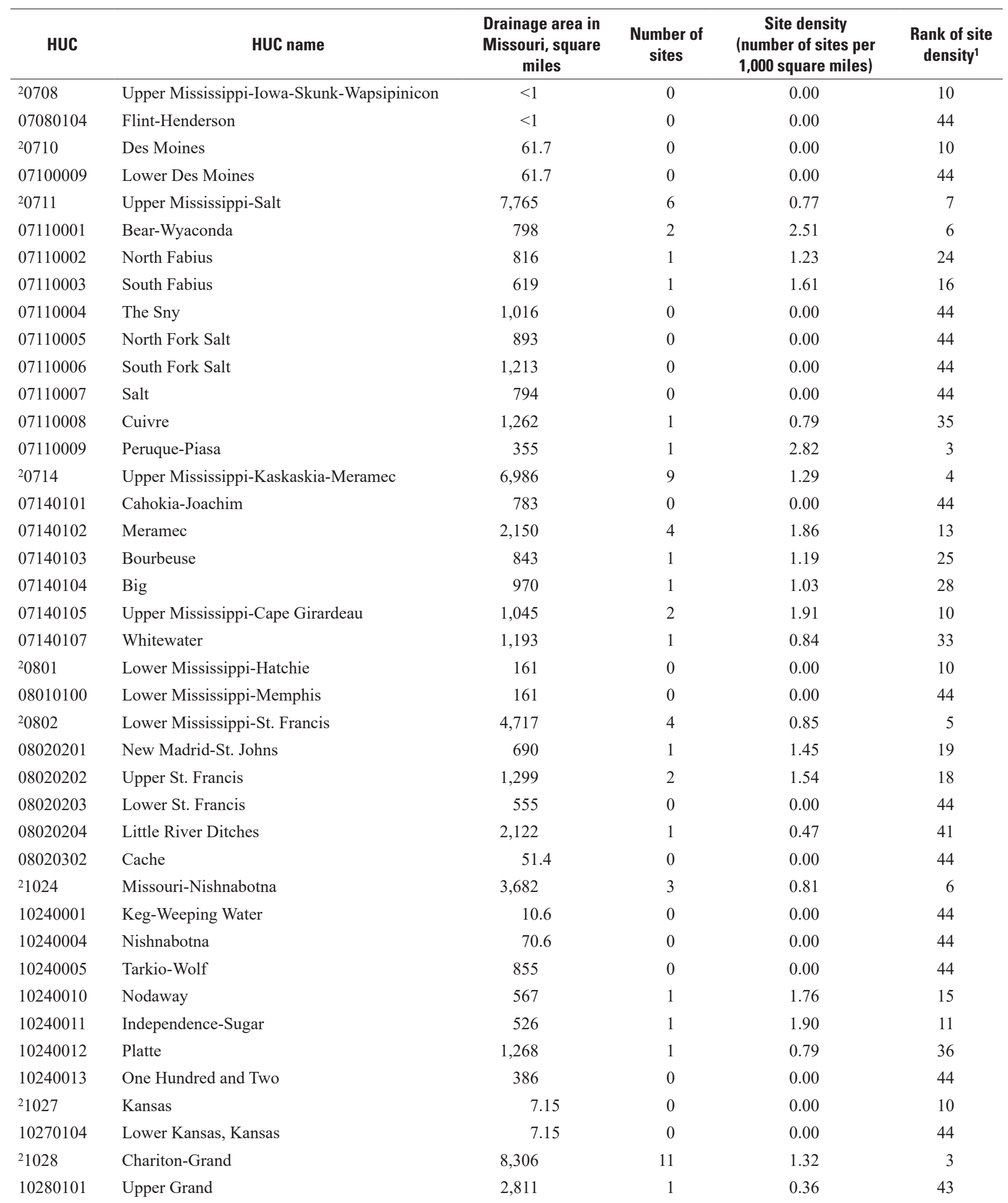


Table 3. Drainage area, density of Ambient Water-Quality Monitoring Network sites, and rank of site density for the sites in each of the 4- and 8-digit hydrologic unit code areas.-Continued

[HUC, hydrologic unit code; <, less than]

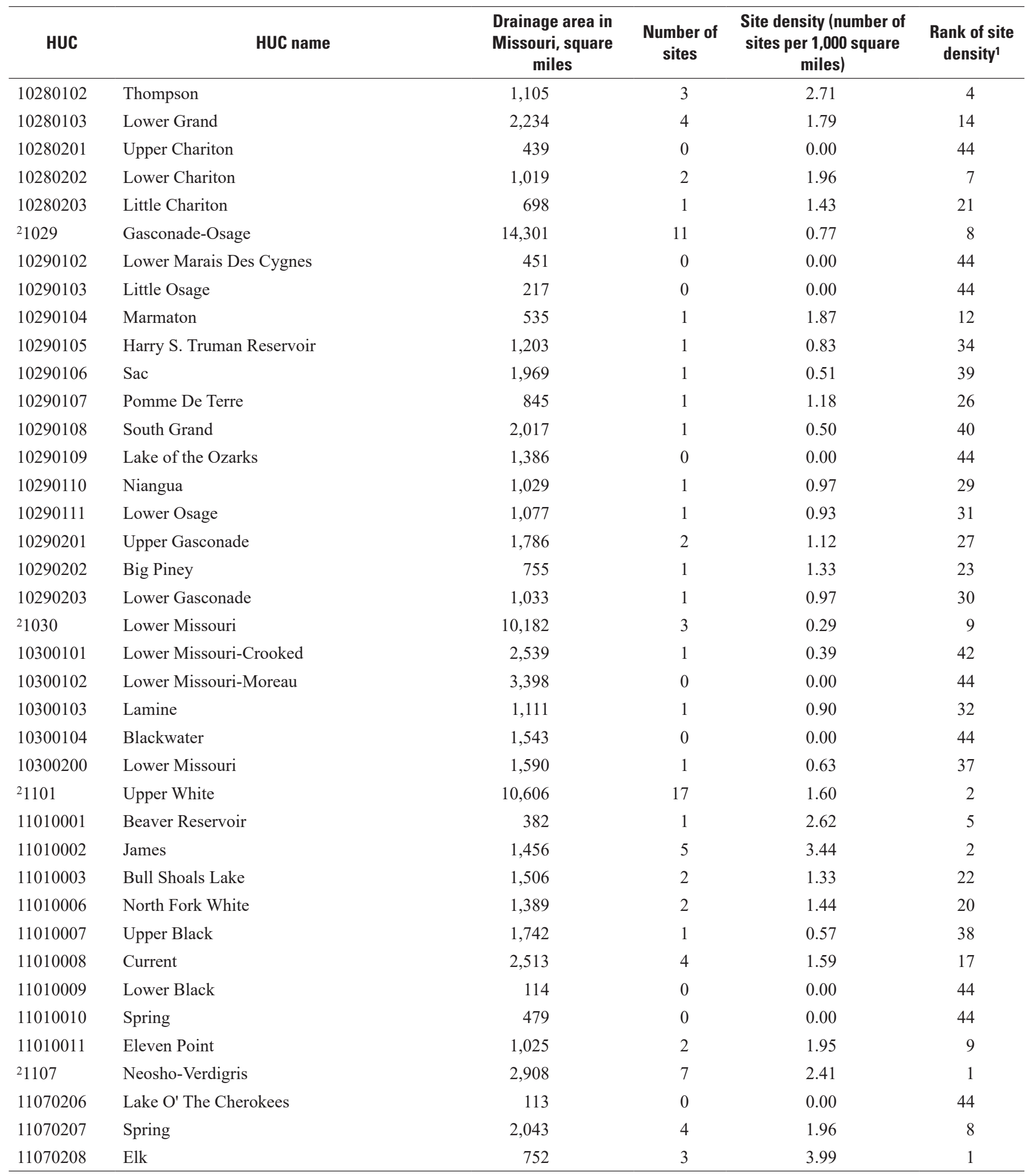

14-digit and 8-digit hydrologic unit codes are ranked separately.

24-digit hydrologic unit code and rank. 
sampling at the remaining 23 nonlake sites of the AWQMN. Discharge is estimated if it is unsafe to measure or mechanical problems prevent measurement. Some water-quality samples do not have an associated discharge because of equipment failures (streamgage or discharge measuring equipment malfunctions).

\section{Data Collection and Analysis Methods}

Water-quality sample collection and analysis methods are documented in more detail in Barr and Davis (2010). Onsite measurements including WT, DO, SC, and $\mathrm{pH}$ were made at each site, and samples for fecal indicator bacteria (EC and FC), TSS, and water-quality constituents were collected and analyzed as described in Barr and Davis (2010). All waterquality samples were analyzed at the USGS National Water Quality Laboratory (NWQL) in Lakewood, Colorado, using procedures described in Fishman and Friedman (1989) and Fishman (1993). Some water-quality sample collection and analysis methods have changed somewhat between water years 1993 and 2017. This change is most evident in the water-quality data of some constituents as temporal fluctuations in the "censored values" (the less than or greater than values in the data). The fluctuations in the censored values are the result of changes in analytical methods or in the method reporting level (MRL) and the laboratory reporting level (LRL) over time. The MRL is defined by the NWQL as the smallest measured concentration of a substance that can be reliably measured using a given analytical method (Childress and others, 1999). The method detection level (MDL) is the minimum concentration of a substance that can be measured and reported with 99-percent confidence that the concentration is greater than zero (Childress and others, 1999). A long-term method detection limit (LT-MDL) is a detection level obtained by determining the standard deviation of 20 or more MDL spiked-sample measurements conducted over an extended period of time. The LRL is computed as twice the LT-MDL.

About 10 to 15 percent of all water-quality samples collected annually for the AWQMN were quality-control (QC) samples and were collected to ensure the data were of sufficient quality to meet the needs of the State of Missouri. QC samples included field equipment blanks and replicate environmental samples and were collected to ensure that equipment was properly cleaned between samples and that samples were consistently sampled and analyzed. QC samples were used to verify and validate the environmental data and sampling techniques throughout the water year and were reviewed annually when the environmental data were approved for archival in the NWIS database (U.S. Geological Survey, 2020). Environmental data not meeting the QC checks were flagged in the NWIS database as erroneous and were not used in analysis. A more detailed description of the type of analysis that is done with the QC data can be found in Barr and Davis (2010). No further discussion of the QC data will be included in this report.
Continuous discharge data from streamgages at or near 47 AWQMN sites (fig. 1; table 1) were collected, processed, quality assured, and stored in the NWIS database according to the methods of Sauer (2001). Instantaneous discharge measurements, to verify and process the continuous discharge record or to provide discharge information for water-quality samples collected at AWQMN sites without continuous data, were made and stored in the NWIS database following the procedures of Turnipseed and Sauer (2010) and Sauer (2001).

\section{Water-Quality and Discharge Data Analysis Methods}

The period of analysis for this study was from water year 1993 through 2017. Data analysis involved retrieving the data from the USGS NWIS database, conditioning the data for analysis, analyzing the data for trends, and analyzing the AWQMN to determine potential data gaps or data redundancy. Results from these analyses can be used in combination with spatial data and other factors to help manage the AWQMN into the future.

\section{Data Retrieval and Conditioning}

Water-quality and discharge data for the analysis period were obtained from the USGS NWIS database (U.S. Geological Survey, 2020) for use in two USGS hydrologic data analysis packages, EGRET (Hirsch and De Cicco, 2015) and R-QWTREND (a parametric statistical time-series model for detecting trends; Vecchia and Nustad, 2020), that were written for the R statistical software (R Core Team, 2020). Data retrieved from NWIS included discharge data and all water-quality data for the 15 constituents of interest for 1993-2017. Because some AWQMN sites were occasionally sampled for other purposes throughout the analysis period, the data retrieved included water-quality data at some sites that were not collected as part of the AWQMN effort. Occasionally, this caused multiple instances of data for the same date in the dataset. The EGRET package relies on daily data for statistics and trend modeling. To avoid skewing the data with the EGRET analysis by potentially overweighting days with multiple samples, duplicate data were removed using the appropriate EGRET function. R-QWTREND uses a 5-day mean for the data so multiple data values on a single day will not substantially affect the statistical results. The final datasets used for EGRET and R-QWTREND analysis are available as a USGS data release (Richards and Barr, 2021).

From water year 1993 through 2002, AWQMN waterquality samples analyzed for nitrate plus nitrite as nitrogen were collected as unfiltered and reported as total values, and then in water years following 2002, samples were collected as filtered samples and reported as dissolved values. In Missouri streams, it is not unusual for total and dissolved nitrate plus nitrite as nitrogen values to be very similar when filtered and unfiltered samples are collected together. To make 
a more complete dataset for analysis, the total values of nitrate plus nitrite as nitrogen were considered "dissolved" in the data analysis (NWIS database parameter codes 00630 and 00631). Changes in NWIS database requirements caused data values for EC to be stored in two different parameter codes (NWIS database parameter codes 31633 and 90902). EC data from both parameter codes were combined for data analysis. Discharge, at the time the water samples were collected, is also stored in two parameter codes (NWIS database parameter codes 00061 and 00060) in the NWIS database depending on how the discharge was obtained. If discharge was obtained from a single physical instantaneous measurement (or estimation) or from a single unit value discharge (typically a 15-minute instantaneous reading from a streamgage with a continuous discharge data record), then it was stored in NWIS database as parameter code 00061. If discharge was obtained as a daily value computed from a continuously recording streamgage (one with a record of discharge data collected at a regular interval, usually 15 minutes), then it was stored in NWIS database as parameter code 00060 . The two discharge parameter codes were combined for data analysis. It is understood that the instantaneous discharge data and daily mean discharge data may represent somewhat different quantities; however, they were analyzed together.

\section{Long-Term Trends and Other Analysis}

Long-term water-quality trends using the AWQMN data were evaluated in two primary ways: using discharge-adjusted trend analysis with R-QWTREND and using nondischargeadjusted data analysis with the Spearman's rank correlation coefficient (U.S. Department of Commerce, 2015). Sites with continuously collected discharge data could be statistically analyzed more rigorously using R-QWTREND, where constituent concentrations could be adjusted for the discharge at the site to determine changes and trends in the data. Sites with no continuous discharge data could not be adjusted for discharge and were analyzed using graphical methods in addition to using Spearman's rank correlation coefficient statistical test to determine if a monotonic relation existed between the constituent concentrations and time or the constituent concentrations and discharge.

\section{Discharge-Adjusted Trends}

Discharge-adjusted water-quality trends were analyzed at 58 sites within the AWQMN in Missouri. A statistical time-series model R-QWTREND, developed by the USGS, was used for analyzing complex discharge-related trends in water-quality constituents (Vecchia and Nustad, 2020). RQWTREND characterizes discharge-related variability at multiple time scales to manage variable discharge resulting from long- and short-term climatic variation so that concentration trends are detected independent of trends in discharge (Nustad and Vecchia, 2020). The model is used for parametric statistical inferences and uses maximum likelihood estimation to determine complex trends, discharge-related variability, and seasonal serial correlation. This package is a collection of functions written in $\mathrm{R}$, a free, open-source language used for statistical and graphical interpretations and computations ( $\mathrm{R}$ Core Team, 2020). An advantage to using this particular model for trend analyses is the ability to model serial correlation among discrete water-quality samples (observations) and to model complex trends during different times as well as different directions, such as upward or downward, within the analysis period. The R-QWTREND software identifies and removes variability in discharge to compute a dischargeaveraged trend and discharge-weighted annual concentrations to represent trends that would have occurred if discharge conditions were the same for each year in the time period. The R-QWTREND software requires a complete record of daily mean discharge measured at the same streamgage as the discrete water-quality samples are collected. Water-quality data must meet the model criteria of a minimum of 60 discrete observations collected during at least a 10 -year period, with four or more samples per year, collected across seasons, for model estimates with low bias. The model also can interpret censored data, but no more than 25 percent of the dataset can be censored. Analyses can be performed with datasets that do not meet the minimum criteria, but the model errors could be highly biased (Vecchia and Nustad, 2020) and should be interpreted with caution. Datasets for the selected constituents at sites used in this study that did not meet the minimum criteria of 60 observations or exceeded 25 percent censored were not used for trend analysis. Some sites with adequate observations and censoring but with a trend period less than 10 years ( 8 to 9 years) were used in trend analysis, but results should be interpreted with caution.

Trend models were developed for the study following steps and default package programming as documented in Vecchia and Nustad (2020) with a minor modification. Prior to outlier identification, imputation of censored values occurs in R-QWTREND's preprocessing script, prepQWdata. Because the code returned errors indicating incomplete convergence for multiple parameters and sites, the "maxiter" variable within the survreg function was increased through trial-and-error from its default value of 30 to 360 to improve convergence. Outliers, as defined within R-QWTREND, were identified by the program, flagged within the model steps, and removed. A table of outliers removed during analysis are available in a USGS data release (Richards and Barr, 2021).

The R-QWTREND program uses Gaussian maximum likelihood estimation to fit the model parameters, chooses the best trend model, and determines the significance levels (probability $[p]$-values) associated with the trends (Vecchia and Nustad, 2020). For this study, results were compared with all nested model results (null [no trend], single-period trend, and two-period trend), and determined to be statistically significant when the "attained significance level" ( $p$-value) was less than the pre-defined threshold of significance (alpha $=0.05$ ). Generalized likelihood ratio tests were used to determine if a trend model was a significantly better fit than the no-trend 
model by the computed $p$-value (Vecchia and Nustad, 2020). The magnitude of uptrends and downtrends was expressed as a percentage change in discharge-weighted concentration modeled during the trend period; the annual model-fitted geometric means and annual discharge-weighted mean concentrations for beginning and ending years of the trend period also were reported. The periods used in the two-period runs were established by observing the full period trend and identifying where the trendline or the overall direction of the observations may have changed. The trend periods were designed to contain at least 10 years of data in each period to ensure a minimum valid trend analysis period was maintained for the R-QWTREND software.

\section{Other Trends and Analysis}

EGRET software was used to facilitate graphical methods to analyze trends in discharge during the period of analysis at 47 sites with continuous discharge. The Python (https://www.p ython.org/) scripting language was used to produce boxplots that graphically display the distribution of data in various groups (Helsel and others, 2020) and scatterplots of constituent values with time or discharge. For the 24 sites that did not have continuous discharge data, a nonparametric Spearman's rank correlation coefficient was used to examine the general trend in constituent values with time.

\section{Graphical Analysis}

Trends in discharge at the 47 AWQMN sites that had continuous discharge data available were analyzed in the $\mathrm{R}$ statistical software with functions within the EGRET package (Helsel and others, 2020). Analysis of discharge was done by creating annual and seasonal scatterplots of mean discharge over time. The EGRET software computed a LOWESS line using the data. The scatterplots and LOWESS line can be graphically examined for general trends in discharge on an annual or seasonal basis.

Boxplots provide a visual summary of the 25 th, 50 th, and 75th percentiles and any extreme values in the distribution. The boxplot consists of the median value (50th percentile) plotted as a horizontal line, and a box is drawn from the 25th percentile to the 75 th percentile. The box length, also known as the interquartile range (IQR), represents one-half of the values. The IQR is insensitive to the presence of extreme values in the distribution. If a median value does not divide the box into two equal parts, it indicates asymmetry in the data distribution. Adjacent values are outside the box and, if within 1.5 times the IQR, are shown as whisker lines. The length of the whisker connected to the 75th percentile represents the value of the largest adjacent value; the length of the whisker connected to the 25 th percentile represents the smallest adjacent value. Values that are more extreme in either direction than the adjacent values are plotted individually. If the median of the data equals the 25 th or 75 th percentile, no center line is shown. If the median of the data equals the 25 th and 75 th percentiles, the box will be plotted as a single line. Boxplots at all AWQMN sites were prepared for each site by constituent so that the data distributions could be compared between and among sites and groups of sites and were created in the Python (https://www.python.org/) scripting language using the Matplotlib package (Hunter and others, 2020). Boxplots of the constituent concentrations by month and season also can often readily reveal general temporal differences in the distribution of the data. Examples of boxplots of constituent concentrations by month and season for each site are shown in figure 7 . All these boxplots are available in a USGS data release (Richards and Barr, 2021).

Scatterplots of concentration versus time and concentration versus discharge for water-quality constituents for all AWQMN sites were created to graphically examine the general trend between concentration and time or concentration and discharge, and are available in a USGS data release (Richards and Barr, 2021). Scatterplots were created in the Python (https://www.python.org/) scripting language using the Matplotlib package (Hunter and others, 2020). Examples of these scatterplots are shown in figure 8. In boxplots and scatterplots created for this report, concentration data that were left censored ("true" values less than the LRL) were substituted with one-half the censored value and those that were right censored ("true" values greater than the value reported) were substituted with 1.5 times the censored value. Data substitutions were determined automatically for each constituent in the EGRET software when the data were retrieved from NWIS. Concentration data that were left censored were depicted in the scatterplot as a stem plot where a vertical line (stem) connects the base to the marker that is plotted at the censored value. The stem signifies that the "true" value of the left censored concentration lies on the continuum between the marker and zero. Concentration data that were right censored were depicted on the graphs as red dots plotted at the censored value. The "true" value of the right censored value is greater than the plotted value of the marker.

\section{Nonparametric Spearman's Rank Correlation Coefficient}

General temporal trends in water quality for the AWQMN sites without continuous discharge data (fig. 1; table 1) were investigated using the nonparametric Spearman's rank correlation coefficient. Water-quality constituents were investigated to determine if a monotonic relation existed between the constituent value and time or the constituent value and discharge. Spearman's rank correlation coefficient does not determine the function relating the two variables but does indicate how well the relation can be described with a monotonic function. The value of the Spearman's rank correlation coefficient indicates a negative or positive relation between the two variables and varies between -1 and 1 (SciPy Community, 2014). The magnitude of the correlation coefficient indicates the strength of the relation where the absolute value of the correlation coefficient is weakly correlated for values less than 0.4 , moderately correlated for values between 0.4 and 0.7 , and strongly correlated for values greater than 0.7 . The Spearman's 


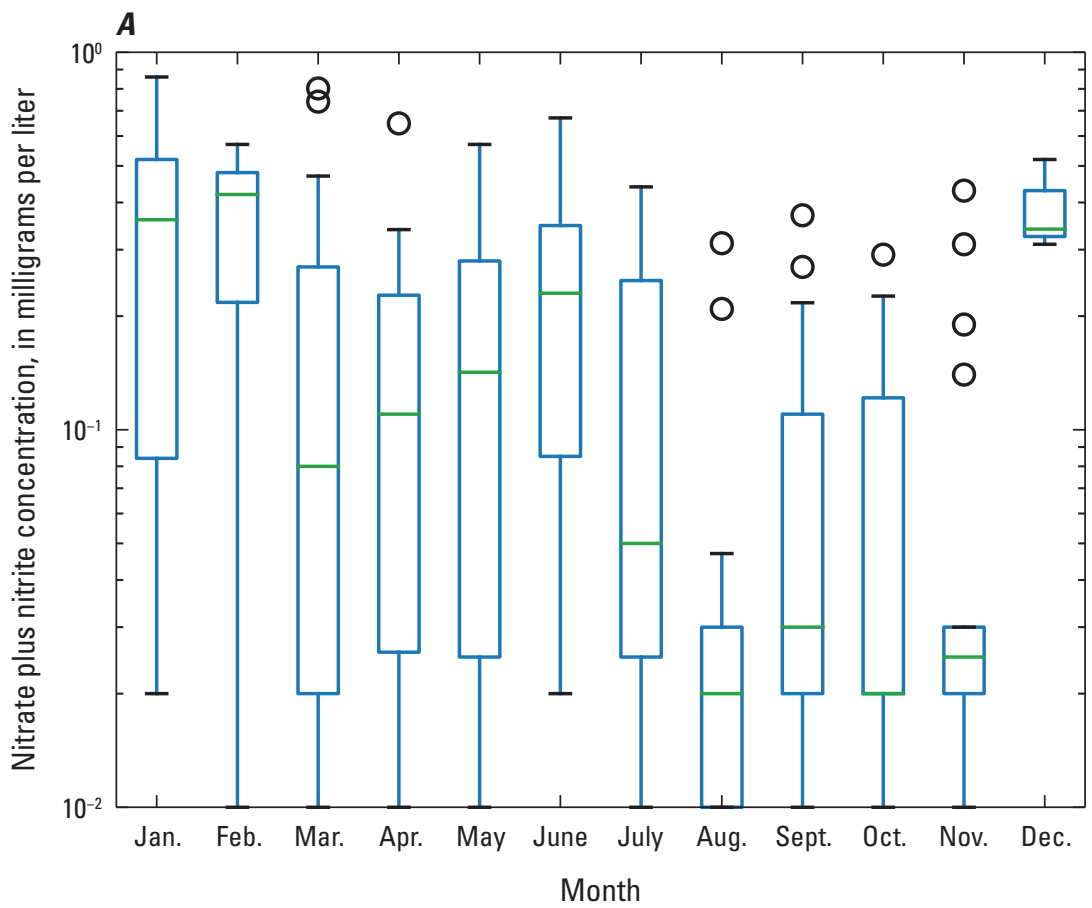

\section{EXPLANATION}

O Upper outlier

T Upper adjacent

75th percentile

Median

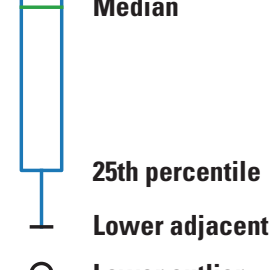

Lower outlier

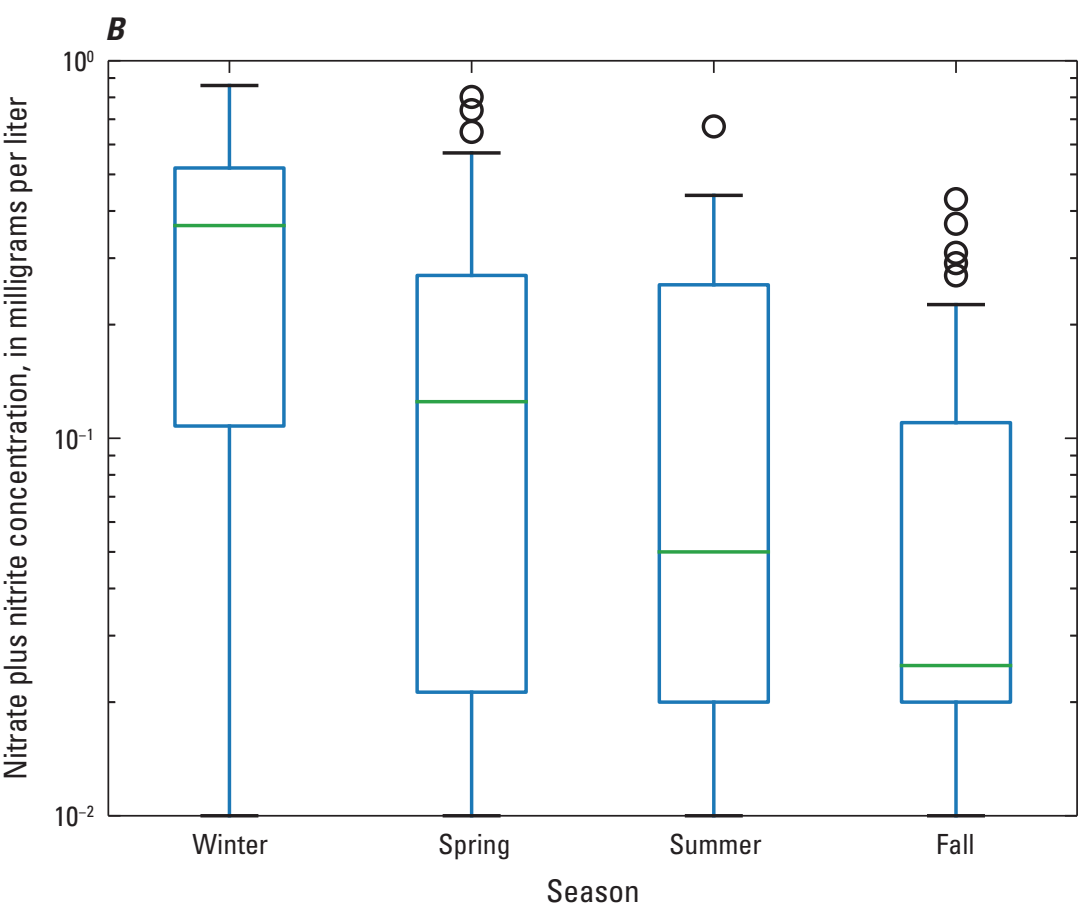

Figure 7. Boxplot examples of constituent data distribution by month and season for nitrate plus nitrite at site 38 (U.S. Geological Survey streamgage 07016400, Bourbeuse River above Union, Missouri). A, Month. B, Season.

rank correlation coefficient was computed using the Python (https://www.python.org/) scripting language using the Scipy package (Virtanen and others, 2020; https://www.scipy.org/). The relation between the two variables was determined to be statistically significant when the $p$-value was less than the pre-defined threshold of significance (alpha $=0.05$ ). Sites with constituent values that had greater than 10 percent censored data were not evaluated. The significance, strength, and direction of the monotonic relation between constituent values and time could be interpreted as a trend in concentration over the analysis period. General trends based on seasonal variation or effects of climate or discharge changes were not investigated for sites that had no continuous discharge data. 


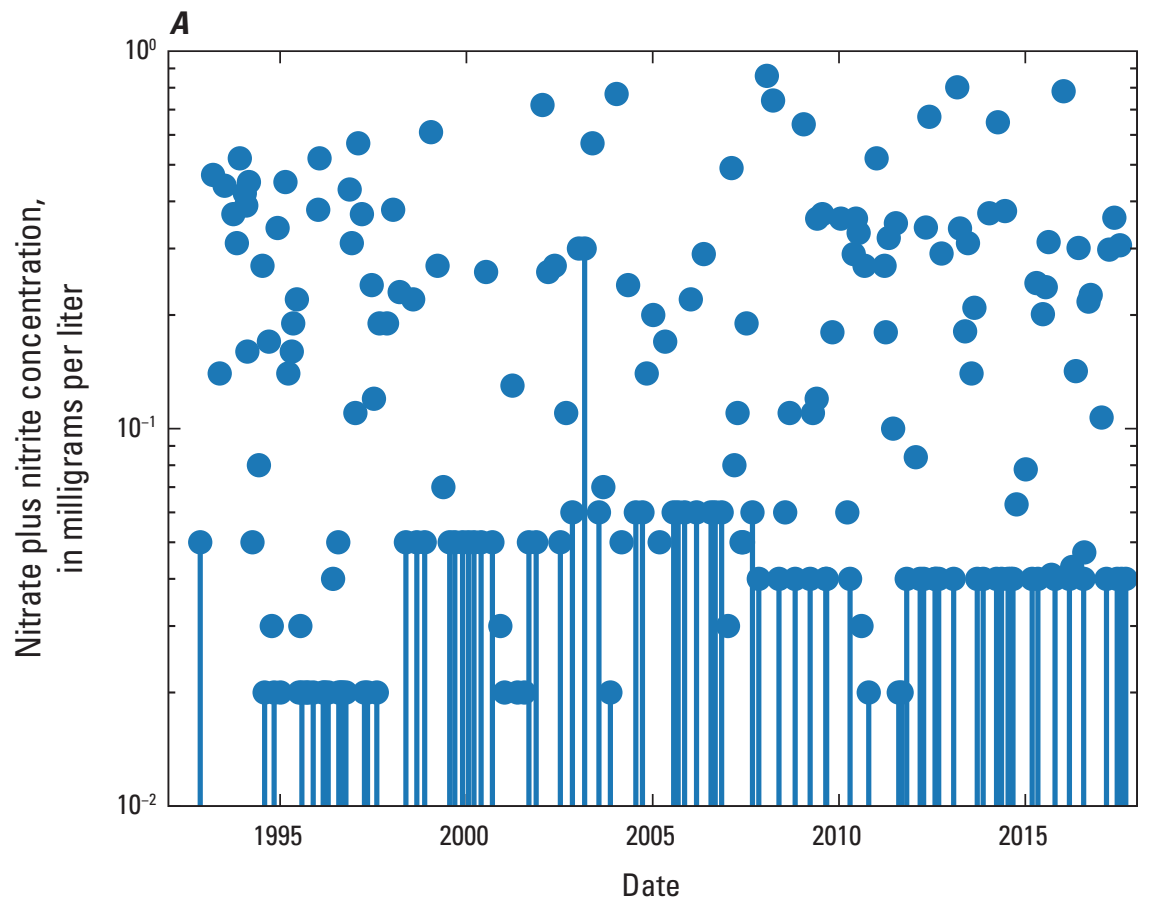

\section{EXPLANATION}

Concentration of constituent-Stem signifies that the "true" value of the left censored concentration lies on the continuum between the marker and zero

Concentration of constituent-The "true" value of the right censored value is greater than the plotted value of the marker.

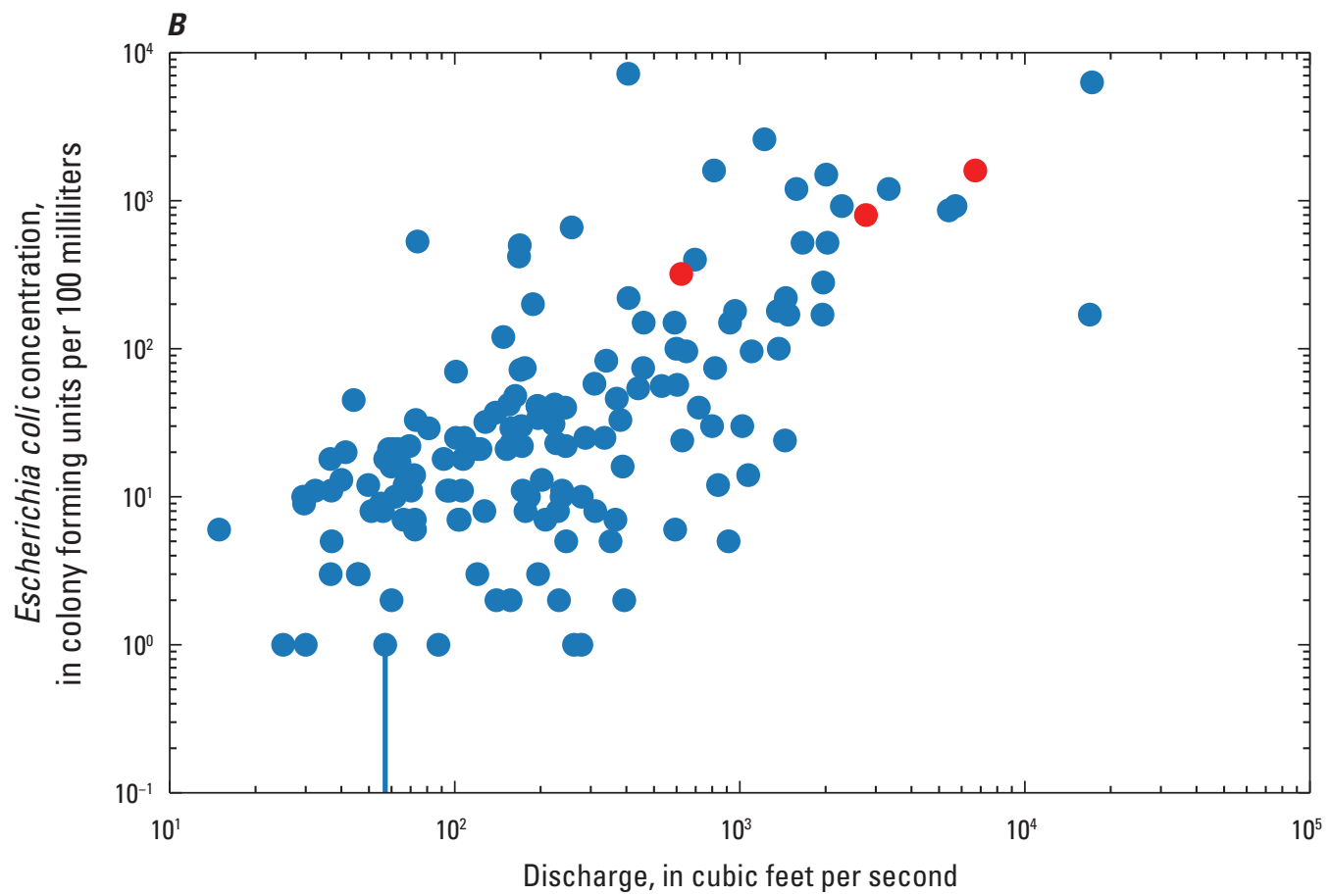

Figure 8. Scatterplot examples for site 38 (U.S. Geological Survey streamgage 07016400, Bourbeuse River above Union, Missouri). A, Nitrate plus nitrite concentration versus time. B, Escherichia coli concentration versus discharge. 


\section{Network Analysis}

Design of a water-quality monitoring network incorporates many considerations when choosing site locations, such as the number and types of sites (whether natural or channelized streams, springs, wetlands, or lakes) and how the sites will be distributed across the landscape (by geography, basin size, land use, physiography, hydrologic boundaries, political boundaries, population, or a combination of these and other factors). Design of the water-quality sampling plan is mostly related to the intended end use of the data and includes determining the frequency of sampling and the constituents of interest. Data uses could include, among others, producing statistical summaries, computing trends, analyzing loads, and compliance monitoring. The water-quality sampling plan could be different for different parts of the monitoring network. Network analysis of the AWQMN was designed to provide information about the existing network that may be beneficial if it should become necessary to modify the network by adding new sites or moving existing sites, to prioritize sites for temporary suspension or discontinuation, to change sampling constituents, to alter sampling frequency, or to institute other potential network changes.

The purpose of the network analysis was to evaluate the following:

- if water-quality data collected for the AWQMN adequately represent the range of discharge conditions at each site,

- the effect of sampling frequency on data distribution,

- the relative sensitivity of selected constituents and sites to simulated changes in the sampling frequency,

- what effects a simulated "minimum" sampling frequency would have on obtaining long-term trends from the simulated dataset,

- if estimating discharge at selected sites could substitute for continuous data in long-term trend analysis, and

- if redundant sites exist in the network.

The network analysis relied heavily on statistical and graphical comparison of the data between sites and constituents. Discharge and water-quality data were suspected not to be normally distributed and were tested for normalcy using the Kolmogorov-Smirnov (KS) test that compares the hydrologic data to a normal distribution with the same mean and standard deviation of the tested hydrologic data (U.S. Department of Commerce, 2013). The KS test was determined to be significant when the $p$-value was less than the pre-defined threshold of significance (alpha $=0.05$ ). The KS test was significant for nearly all the tested comparisons, which indicated that the hydrologic data distributions were significantly different than the normal distribution in nearly all cases. Because the data were not normally distributed in nearly all cases, nonparametric statistical tests were used for all statistical data comparison.
The nonparametric two-sample Kruskal-Wallis (KW) rank-sum test (Helsel and others, 2020) was used to test for significant differences in the medians of the data. The assumption for the two-sample KW test is that the data groups have the same shape and distribution and that the null hypothesis is the groups have the same median. A significant difference in the two-sample $\mathrm{KW}$ test is indicated if the $p$-value of the test is less than the pre-defined threshold of significance (alpha $=0.05$ ), which implies the medians of the groups are different. The nonparametric two-sample Kolmogorov-Smirnov (KS2) test and the Kuiper test were used to determine if significant differences in the data distributions existed. The KS2 test is similar to the KS test for normality. The KS2 test compares two data samples that are assumed to be from the same population, and the null hypothesis for this test is that the two samples have the same distribution (U.S. Department of Commerce, 2016). The KS2 test indicates that a significant difference between the two sample distributions exists if the $p$-value is less than the pre-defined threshold of significance (alpha $=0.05$ ). The Kuiper two-sample test is similar to the KS2 test but has been modified so that it is sensitive at the central tendency and the tails of the distribution (Kuiper, 1960; Paltani, 2004). The combination of the two-sample KW and the Kuiper test (and sometimes combined with the KS2 test) was used to evaluate the data distribution more fully than when using either test individually. Because of the large number of statistical comparisons that were necessary, comparisons were automated with the Python (https://www.python.org/) scripting language using the Scipy package (https://www.scipy.org/) for the two-sample KW and KS2 tests and the Astropy package (https://www.astropy.org/) for the Kuiper test.

\section{Discharge Data Range Evaluation}

Discharge is collected continuously by a USGS streamgage at or near 47 AWQMN sites (fig. 1; table 1), and discharge is recorded with nearly every water-quality sample collected as part of the AWQMN (termed sampled discharge), so the two can be evaluated together. The purpose of evaluating the range of the sampled discharge to the full range of discharge potentially provides an indication of how the water-quality samples may represent the range of natural discharge conditions at the AWQMN sites. This type of analysis can be helpful for identifying those cases where the distribution of sampled discharges at a site does not adequately represent the distribution of the total population of daily mean discharges; as a consequence, the fluxes or trends estimated for constituents at those sites should be treated with caution. To evaluate if the sampled discharge distribution at the AWQMN sites adequately represented the full range of discharge conditions at each site, sampled discharge data were compared to the daily mean discharge at continuous discharge sites.

Boxplots of the continuous discharge and the waterquality sample discharge at each site for each constituent were created to graphically compare and evaluate the data distribution. To determine if the sample discharge data distribution 
is significantly different from the daily data distribution, the two-sample KW and Kuiper statistical tests were computed. The two-sample KW test and the Kuiper test were used in combination to evaluate the data distribution more fully than when using either test individually. Minimum and maximum sampled discharges at each site were compared to the daily mean discharge record during the period of analysis to determine the proportion of time at each site that the daily mean discharge was less than the minimum and greater than the maximum sample discharge. This information can be used to help understand whether the water-quality samples collected at each site generally represent the range of discharge conditions that existed during the period of analysis.

\section{Sampling Frequency Analysis}

Random data collection from a water-quality monitoring network like the AWQMN, with a number of sites across a large geographic area, is usually inefficient and impractical. Sampling design for a water-quality monitoring network is sometimes targeted toward specific time periods driven by basin uses, such as agricultural or recreational, where sampling is intensified during or limited to the particular time period of interest. Occasionally, sampling design for a water-quality monitoring network is targeted toward specific events that are often tied to specific basin practices, such as urban runoff, agricultural runoff, or permitted discharge monitoring, where unusually high or low discharge or precipitation events are preferentially sampled. However, for general water-quality monitoring, which the AWQMN sites are designed to observe in many cases, samples are typically collected monthly, bimonthly, seasonally (or quarterly), semiannually, annually, or on some other temporally predictable schedule.

Although the "true" population distribution of the waterquality constituents in the AWQMN will never be known, given a high enough data-collection frequency and a sufficient period of collection, the data distribution of the samples is expected to approach the distribution of the population. Assuming that the highest data frequency that was collected (generally monthly at 28 AWQMN sites) during the period of analysis was sufficient to represent the population distribution, changes in data collection frequency can be simulated and compared to this highest frequency dataset. To explore how a change in the sampling frequency at the AWQMN sites might have affected the data distribution compared to the highest frequency dataset, various simulated sampling frequencies were created as subsets from the AWQMN dataset for 10 constituents plus discharge at 28 sites. Sites and constituents were included in the analysis if the constituent at a given site had a mean sampling frequency of 10 or more samples per year for water years sampled between 1993 and 2017 (table 2). Sampling frequency varied among the water-quality constituents for any given site for a given water year and during the analysis period. Typically, however, the water-quality constituents of $\mathrm{Cl}, \mathrm{TPb}, \mathrm{DPb}, \mathrm{TZn}$, and $\mathrm{DZn}$ were only sampled from 2 to 4 times per year and were not included in the analysis. The frequency of sampling at the selected sites allowed for the analysis of 10 water-quality constituents: DO, $\mathrm{SC}, \mathrm{pH}, \mathrm{WT}, \mathrm{TSS}, \mathrm{NO}$, DP, TP, EC, and FC. The discharge value at the time of sampling also was included as a component in the analysis.

The data subsets to be evaluated were produced using a structured semirandom selection from the full AWQMN dataset at the selected sites using regular interval frequency selection rules. The simulated frequency data subsets were prepared for analysis as shown in table 4 . The data subsets included 1 sample per season (3 subsets), 2 samples per season (3 subsets), 6 samples per year (2 subsets), 2 samples per year, (6 subsets), and 1 sample per year (12 subsets). If multiple samples of a particular constituent existed within the month, one sample would be programmatically chosen at random. For example, if there were five daily WT values in the month of October for water year 2015 at site 34, when preparing a subset for temperature that included values from October, one of the five values would be programmatically selected at random.

The data distribution of each subset was tested against the full dataset distribution of the various site-constituent combinations using the two-sample $\mathrm{KW}$ test to evaluate the central tendency of the data and using the Kuiper and KS2 tests in combination to evaluate the data distribution more fully than when using either test individually. A statistical test result was obtained independently for each site-constituent pair for each of the 26 simulated sampling frequency datasets.

The two-sample KW, Kuiper, and KS2 resultant $p$-value data were aggregated for each site-constituent combination for each simulated sampling frequency group (table 4). An aggregated result was considered statistically significantly different in two ways: a union aggregation, termed F_UNION and an intersection aggregation, termed F_INTERSECTION. A significant difference for the F_UNION aggregate was determined if at least one of the tests at a given simulated sampling frequency at a particular site for a particular constituent showed a $p$-value less than the pre-defined threshold of significance (alpha $=0.05$; F_UNION significant if KW, Kuiper, or KS2 $p$-value less than 0.05). A significant difference for the F_INTERSECTION aggregate was determined if all tests at a given simulated sampling frequency at a particular site for a particular constituent showed a $p$-value less than the pre-defined threshold of significance (alpha $=0.05$; F_INTERSECTION significant if $\mathrm{KW}$, Kuiper, and KS2 $p$-value less than 0.05). An example of how the aggregation (F_UNION or F_INTERSECTION) was evaluated to be significant or nonsignificant, follows. Suppose that for generic site A, a reduced dataset representing a quarterly sampling frequency, and constituents NO3, DP, and TP, the comparison of the full dataset and the quarterly dataset was analyzed for significant differences using the KW, Kuiper, and KS2 tests. Assume the results of each of the individual tests (where a value of 1 represents a significant difference) for $\mathrm{NO} 3$ were 1, 0 , and 0 ; for DP were 0,0 , and 0 ; and for TP were 1 , 1 , and 1 for the KW, Kuiper, and KS2 tests, respectively. The F_UNION aggregation for this example would evaluate as significant for NO3, nonsignificant for DP, and significant for TP. 
The F INTERSECTION aggregation for this example would evaluate as nonsignificant for NO3, nonsignificant for DP, and significant for TP.

Because of the way that the significant difference aggregates were defined, the F_UNION aggregate of the statistical tests is considered to be the most liberal aggregation. The total number of significant differences for the F_UNION and F_INTERSECTION groups was summed for each simulated sampling frequency group (table 4), for each site, and for each constituent. The percent of significant differences for the F_UNION and F_INTERSECTION groups was computed for each simulated sampling frequency group, for each site, and for each constituent, and a mean of the percent of significant differences of the F_UNION and F_INTERSECTION aggregated results was computed. The percentage of significant differences for the F_UNION and F_INTERSECTION aggregates and the mean of the percentage of the two groups were then ranked for each sampling frequency group, for each site, and for each constituent.

Multiple statistical comparisons (in this case, 26 for each site-constituent pair) can lead to an increased chance of type 1 errors (false positives) and can lead to about a 75-percent chance of obtaining at least 1 false positive for 26 comparisons for each statistical test. No correction was made to the predefined threshold of significance (alpha $=0.05$ ) to account for the increased chance of false positives. The potential increased chance of false positives is mitigated by the way the reduced frequency datasets were produced, by blending the F_UNION and F_INTERSECTION aggregates, and by the fact that more significant differences would favor not reducing the sampling frequency. The way the reduced datasets were constructed (particularly for the 1 and 2 samples per season groups and the 6 samples per year group) ensure even distribution during the year that would include the seasonal fluctuation (that a purely random selection would have a better chance of missing). Thus, the possibility of experiencing a false positive owing to chance would be reduced. Additionally, for the F_INTERSECTION aggregate to indicate a significant difference, all individual statistical tests for the site-constituent-dataset combination must indicate a significant difference. The chances of multiple false positives on the site-constituent-dataset combination of any given test would probably be small (if, in fact, there is no significant difference indicated). Blending the F_UNION and F_INTERSECTION aggregates by averaging will somewhat mitigate false positives if they occur. Lastly, the purpose of the sampling frequency analysis is to determine if a reduction of sampling frequency would produce a similar data distribution as a monthly sampling frequency. Erroneous significant differences that may be the possible result of increased type 1 errors in multiple comparisons would tend to lead to the conclusion that reduction of sampling frequency would not produce similar data distributions and would favor not reducing the sampling frequency.

\section{Trends from Simulated Reduced Frequency Dataset}

Sites that had defined long-term trends from the RQWTREND analysis and had sufficient sampling frequency (monthly) were reanalyzed using a dataset designed to simulate a reduced frequency sampling (approximately quarterly). The purpose was to explore if the same or similar long-term trend would be identified for each selected constituent at each given site using a reduced dataset that was obtained with the unreduced dataset. A subset of the AWQMN data at 22 sites was prepared using available data collected in the months of March, June, September, and December for each year of the analysis period. Other sampling frequencies were not explored. Long-term trends were analyzed in the same way on the simulated reduced-frequency dataset as on the original monthly dataset for the analysis period (1993 to 2017; see the methods description in "Discharge-Adjusted Trends" subsection). The 11 water-quality constituents (Cl, DO, SC, pH, WT, TSS, NO3, DP, TP, EC, and FC) were analyzed for long-term trends using the simulated reduced-frequency dataset. Because the frequency of $\mathrm{Cl}$ sampling was 4 times per year or less at most sites, only sites 6,34 , and 43 had sufficient $\mathrm{Cl}$ sampling frequency to be reanalyzed using a simulated reducedfrequency dataset. Trace elements (TPb, DPb, TZn, and DZn) were not analyzed because sampling frequencies were too low to allow for a reduced-frequency dataset that would meet the minimum requirements for analysis with R-QWTREND.

\section{Continuous Discharge Estimation at Ungaged AWQMN Sites}

A critical element of trend analysis for the AWQMN data is the daily mean discharge component. To explore the viability of estimating daily mean discharge at ungaged AWQMN surface-water sites (spring and lake sites were not estimated), discharge data from existing streamgages within the same basin or in an adjacent basin were compared to discharge data that were measured at the AWQMN site at the time of sample collection. Alternate discharge sites were chosen if they were spatially near the selected AWQMN site and had a daily mean discharge record that spanned all or most of the sampling period at the selected AWQMN site. The estimated discharge at the AWQMN site was scaled from the daily mean discharge at the alternate site by the ratio of the drainage area of the AWQMN site to the drainage area at the alternate site.

Scatterplots, boxplots, and time-series plots were prepared to graphically examine the comparison of the estimated daily mean discharge with the discharge data measured at the time of sample collection. The measured discharge data and the scaled alternate daily mean discharge data were regressed to determine the best fit model that related the values. Regression was done in Python using the statsmodels package (Seabold and Perktold, 2010; https://www.statsmodels.org/stable/index.html) on the untransformed data and on log transformed data. Correlation coefficients, or r-squared $\left(r^{2}\right)$ values, were computed for the 
regression models. Models were considered strongly correlated for $r^{2}$ values greater than 0.7 , moderately correlated between 0.4 and 0.7 , and poorly correlated for values less than 0.4 .

Regression models were developed relating the daily mean discharge at the alternate site to the measured discharge at the ungaged AWQMN site when samples were collected. Various regression models were evaluated on area-weighted log transformed data and included linear, polynomial, logarithmic, power, and exponential functions. For the 21 ungaged AWQMN sites, the power function regression model (eq. 1) had the largest $r^{2}$ of all the regression models and was used to compute the estimated daily mean discharge from the alternate discharge sites at all except site 29. A linear regression model (eq. 2) was used to compute estimated daily mean discharge for site 29 (Osage River below St. Thomas, Missouri) because its $r^{2}$ of 0.900 was slightly better than the power function regression model $r^{2}$ of 0.778 . It is suspected that because there are few discharge inputs between site 29 and its alternate site, Osage River near Bagnell, Missouri (not shown on figures), owing to their relative proximity, and because the discharge in the river at both sites is largely controlled by the releases from Bagnell Dam (not shown on figures) just upstream from the alternate site, it follows that discharge at these two sites is more likely to be linearly related than most other sites evaluated.

$$
Q_{\text {est }}=a\left(D A R \times Q_{a l t}\right)^{\beta}
$$

where,

$Q_{\text {est }}$ is the estimated discharge at the ungaged
AWQMN site, in units of cubic feet
per second,
is the coefficient computed for the power
function,
is the ratio of the drainage area at the ungaged
AWQMN site to the drainage area of the
alternate streamgage site,
is the daily mean discharge of the alternate
site, in units of cubic feet per second, and
$Q_{\text {alt }}$
is the scaling exponent computed for the
power function.

$$
Q_{\text {est }}=m\left(D A R \times Q_{a l t}\right)+b
$$

where,

$$
\begin{gathered}
Q_{\text {est }} \quad \text { is the estimated discharge at the ungaged } \\
\text { AWQMN site in units of cubic feet } \\
\text { per second, } \\
m \quad \text { is the coefficient of slope computed for the } \\
\text { linear function, } \\
\text { is the ratio of the drainage area at the ungaged } \\
\text { AWQMN site to the drainage area of the } \\
\text { alternate streamgage site, } \\
Q_{a l t} \quad \begin{array}{c}
\text { is the daily mean discharge of the alternate } \\
\text { site, in units of cubic feet per second, } \\
\text { is the intercept computed for the linear } \\
\text { function. }
\end{array}
\end{gathered}
$$

During analysis, data were lagged or advanced by as many as 2 days for sites on the same stream. It is suspected that because most alternate sites on the same stream were typically within the daily travel time of water from the AWQMN site, only one site (of 10 with alternate sites on the same stream) showed marginal improvement in the $r^{2}$ value from 0.585 to 0.649 . Therefore, to keep the estimation technique consistent for all sites, no data lag was used in any of the sites when estimated daily mean discharge was computed from the regression equation.

Model residuals were evaluated using the LaGrange multiplier heteroscedasticity test by White (1980) in Python using the statsmodels package (https://www.statsmodels.org/ dev/generated/statsmodels.stats.diagnostic.het_white.html\#sta tsmodels.stats.diagnostic.het_white). Heteroscedasticity means unequal scatter. A statistically significant heteroscedastic test of the residuals can indicate that the regression model may not provide the best estimate of the relation between the two variables and that there may be some degradation in the precision of the coefficients of the regression model (Williams, 2020). This degradation of precision could presumably affect the estimated discharge values. The two-sample KW and Kuiper tests were used to test for significant differences in the medians and distributions between the sampled discharge data and the scaled alternate daily mean discharge data. Lagging or advancing the daily data by as many as 2 days from alternate sites on the same stream was evaluated to determine if that would improve the correlation to the measured discharge. Estimating the discharge from alternate sites using the unit value discharge data was beyond the scope of this study and was not explored.

\section{Potentially Redundant Site Determination in the AWQMN}

Redundant sites within a monitoring network may add unnecessary complexity to the sampling of the network, generate unnecessary data, add unnecessary expense, and potentially add little to the interpretation of the water-quality data. The AWQMN was evaluated to identify potentially redundant sites within various grouping categories. Sites were considered potentially redundant if the data collected at a pair of sites within the same grouping category showed little difference in the data distribution. It is emphasized that the potential specific use of any of the data at any of the sites was not considered while searching for redundant sites.

The frequency of sampling was not a limitation for this analysis, so all 71 sites and all 15 constituents were used for comparison within the grouping categories. The sites fell into various grouping categories: class, Missouri and Mississippi Rivers, 4-digit HUC, 8-digit HUC, dominant land use, and watershed indicator site. All of these grouping categories except the Missouri and Mississippi Rivers category are found in table 1. Sites on the Missouri and Mississippi Rivers were grouped and analyzed separately. Within each grouping category, sites were evaluated by identifying site-constituent pairs with statistically significant differences using the two-sample $\mathrm{KW}$ statistical test to determine differences in the median and 
the Kuiper statistical test to determine differences in the data distribution. Each site-constituent pair was compared with every other site-constituent pair in the given analysis group except for the watershed indicator sites where every site in the basin was compared to the watershed indicator site. Median values and data distribution were determined to be significantly different if the $p$-value was less than the pre-defined threshold of significance (alpha $=0.05$ ) for the two-sample KW and Kuiper tests. Using the results of the combination of the two statistical tests produced an aggregated result. The aggregated result was considered statistically significantly different in two ways: a union aggregation, termed R_UNION and an intersection aggregation, termed R_INTERSECTION. A significant difference for the R_UNION aggregate was determined if at least one of the tests of the given constituent for the given site pair showed a $p$-value less than the pre-defined threshold of significance. A significant difference for the R_INTERSECTION aggregate was determined if both tests of the given constituent for the given site pair showed a $p$-value less than the pre-defined threshold of significance.

An example of how the aggregation (R_UNION or R_INTERSECTION) was evaluated to be significant or nonsignificant, follows. Suppose that for generic sites A and $\mathrm{B}$ and constituents NO3, DP, and TP, the comparison of the full dataset at site A to the full dataset at site B for each constituent was analyzed for significant differences using the KW and Kuiper tests. Assume the results of each of the individual tests (where a value of 1 represents a significant difference) for NO3 were 1 and 0 , for DP were 0 and 0 , and for TP were 1 and 1 for the KW and Kuiper tests, respectively. The R_UNION aggregation for this example would evaluate to significant for NO3, nonsignificant for DP, and significant for TP. The R_INTERSECTION aggregation for this example would evaluate to nonsignificant for $\mathrm{NO}$, nonsignificant for DP, and significant for TP.

The total number of significant differences for the $\mathrm{R}_{-}$ UNION and R_INTERSECTION aggregates was summed for each site pair. The percentage of significant differences for the R_UNION and R_INTERSECTION aggregates was computed for each site pair, and a mean of the percent of significant differences of the R_UNION and R_INTERSECTION aggregated results was computed. Site pairs were considered similar (possibly redundant) if the mean of the percentage of significant differences of the R_UNION and R_INTERSECTION aggregated results was less than 20 percent.

The pre-defined threshold of significance (alpha $=0.05$ ) was not corrected to account for the increased possibility of type 1 errors (false positives) when multiple statistical comparisons are used. The purpose of the redundant site determination was to identify sites with similar data distributions. In this analysis, erroneous significant differences indicated by the increased chance of determining a false positive with multiple statistical comparisons could lead to the interpretation of a particular site pair not being similar. The increased chance of determining a false positive is somewhat mitigated by the blending of the R_UNION and R_INTERSECTION aggregated results by also ranking the mean of the percent differences for R_UNION and R_INTERSECTION results.

\section{Spatial Data Compilation}

Basin-specific information for the sites in the AWQMN were gathered to help managers prioritize sites based on the relative value of each site's basin attributes. Tabulated spatial information specific to the site, such as total feature count, total length, and total area of point, line, and area features such as streams designated as 303(d) reaches, springs, losing streams, caves, sinkholes, mines, outfalls, major water users, population, and many others, are presented in table 5 . The original source for the spatial data used to compile table 5 (except for population) was the Missouri Department of Natural Resources, but the data were stored and distributed by the Missouri Spatial Data Information Service (MSDIS). The publicly available data were retrieved from MSDIS (Missouri Spatial Data Information Service, 2020) and consisted of data of various dates ranging from 2007 to 2020 .

Sites 6, 8, 10, 34, and 43 on the Missouri and Mississippi Rivers; sites 31, 48, 60, and 63 (springs); and site 54 (lake) are not included in table 5 because either most of the Missouri and Mississippi River Basin was outside of Missouri or the sites had no drainage area defined. Except for population, the values in table 5 are for only the portion of the basin that lies within the boundary of the State of Missouri and do not include any data from adjacent States. The various datasets were clipped to the basin boundary for each individual site, then the results were tabulated for the clipped features within the basin boundary.

Population data, based on the 2010 Census, were obtained from the Center for International Earth Science Information Network (2017), and consisted of gridded data with an approximate resolution of 1 square kilometer. Population data were clipped with the AWQMN basin boundaries and a total population within the basin was computed from the clipped data.

\section{General Water-Quality Conditions, Long-Term Trends, and Network Analysis}

Spatial distribution of the water-quality constituents can be used to describe how the general water-quality conditions vary across the State. Long-term trends were investigated to determine sites that indicated significant changes in the constituent concentrations during the period of analysis. The AWQMN network was analyzed to identify data redundancies and data gaps, to determine which sites and constituents 
are most sensitive to changes in sampling frequency, and to understand how changes in sampling frequency might affect the ability to analyze long-term trends.

\section{General Water-Quality Conditions}

From previous reports, water-quality conditions vary across the State, but similar water-quality conditions usually coincide with similar land use. General discussion of waterquality conditions at the sites in the AWQMN is provided in summary reports prepared on an annual basis (Barr, 2010, 2011, 2013, 2014, 2015; Barr and Schneider, 2014; Barr and Heimann, 2016; Barr and Bartels, 2018, 2019), and that discussion will not be repeated here. As a general overview for discussion in this report, maps of median values for the period of analysis for each of the 15 constituents at each site included in this report were prepared to show the general range and spatial distribution of the data in the State. An example of one of the maps for total phosphorus is shown in figure 9. These maps can be obtained from a USGS data release (Richards and Barr, 2021). A table of summary statistics for water years 1993 through 2017 of the number of values, count of censored values, minimum, 25th percentile, median, mean, 75th percentile, and maximum for each water-quality constituent at each site was prepared and is available from a USGS data release (Richards and Barr, 2021).

Most of the median values of DO at AWQMN sites range generally between 8 and 13 milligrams per liter $(\mathrm{mg} / \mathrm{L})$ and are relatively evenly distributed across the State. Some of the largest median values of DO occur at sites in the James River 8-digit HUC (11010002; table 1) in the Springfield Plateau section of the Ozark Plateaus Province. Median values of TSS are largest in agricultural areas of western and northwestern Missouri in the OSPL and DTPL of the Central Lowland Province as well as the Missouri and Mississippi River. Median values of nutrient constituents (NO3, TP, and DP) tend to be larger in agriculturally dominated areas although they are not distributed the same way. Median values of NO3 tend to be larger in southwest Missouri primarily in the Springfield Plateau section of the Ozark Plateaus Province, whereas TP and DP median values tended to be larger in the cropland dominated areas of southwest, west, northern, and southeast Missouri and smallest in the forested and pasture dominated Salem Plateau section of the Ozark Plateaus Province. The median values of fecal indicator bacteria (EC and FC) tended to be largest in the DTPL of the Central Lowland Province and smallest in the Salem Plateau section of the Ozark Plateaus Province. The median values of $\mathrm{TPb}$ and $\mathrm{DPb}$ tended to be largest in the areas of past and present lead mining activities in southwest Missouri and in the vicinity of the St. Francois Mountains. The median values of TZn and DZn tended to be largest in the areas of past mining activities in southwest Missouri. The median $\mathrm{Cl}$ values tended to be lowest in the Salem Plateau section of the Ozark Plateaus Province.

\section{Long-Term Trends and Other Analysis}

For sites with continuous discharge available or where it could be estimated from nearby streamgages, dischargeadjusted water-quality trends were analyzed for the period of analysis. For sites where no continuous discharge was available, the relations between constituent concentration and time and constituent concentration and discharge were investigated.

\section{Long-Term Discharge-Adjusted Trends in Selected Water-Quality Constituents}

Long-term trends were identified and used to assess if water-quality conditions have changed or remained the same for selected sites using the available period of record within water years 1993 through 2017. Comparisons of trends and water-quality conditions to State water-quality standards were identified where applicable. All data used in the water-quality trends and conditions analyses are available from a USGS data release (Richards and Barr, 2021).

Among the 71 sites in the AWQMN, 58 sites (table 1) had datasets that were suitable for trend analysis with RQWTREND for one or more of the selected constituents. Some sites did not fully meet the requirements for reliable trends and were flagged as not meeting the minimum modeling requirements in table 6. Additional modeling information, such as number of observations, percent of censored observations, and trend period, are included with the trend results in table 6 . Sites were grouped by class (table 1) on some figures to allow sites within the same class to be compared more easily with each other.

\section{Physical Properties}

Physical properties selected for trend analysis are WT, $\mathrm{DO}, \mathrm{SC}$, and $\mathrm{pH}$. These physical properties are measured in the field at the time of sample collection and can assist in the understanding of the current conditions of a stream at the time of sampling. Many constituents are dependent on WT and can degrade or react at certain temperatures. Particular fish species also can thrive within certain ranges of WT better than other species. DO is important to aquatic life for survival. Lower concentrations of DO can be an indicator of higher concentrations of suspended particulates and organic material in the stream that can limit light and algal photosynthesis or increase demand for DO through oxidation of reduced organic material. The solubility of DO in water also decreases with increasing temperature. SC is the measurement of dissolved ions in the water and the ability of dissolved ions to carry an electrical charge or current at a specified temperature. $\mathrm{pH}$ is a measurement of the acidity or alkalinity of water and is a useful indicator of increasing pollution and is used to indicate the toxicity criteria for some aquatic life standards.

Of 58 sites, 52 met the requirements necessary to be analyzed with R-QWTREND software for trends in WT. WT was the physical property with the lowest number of 


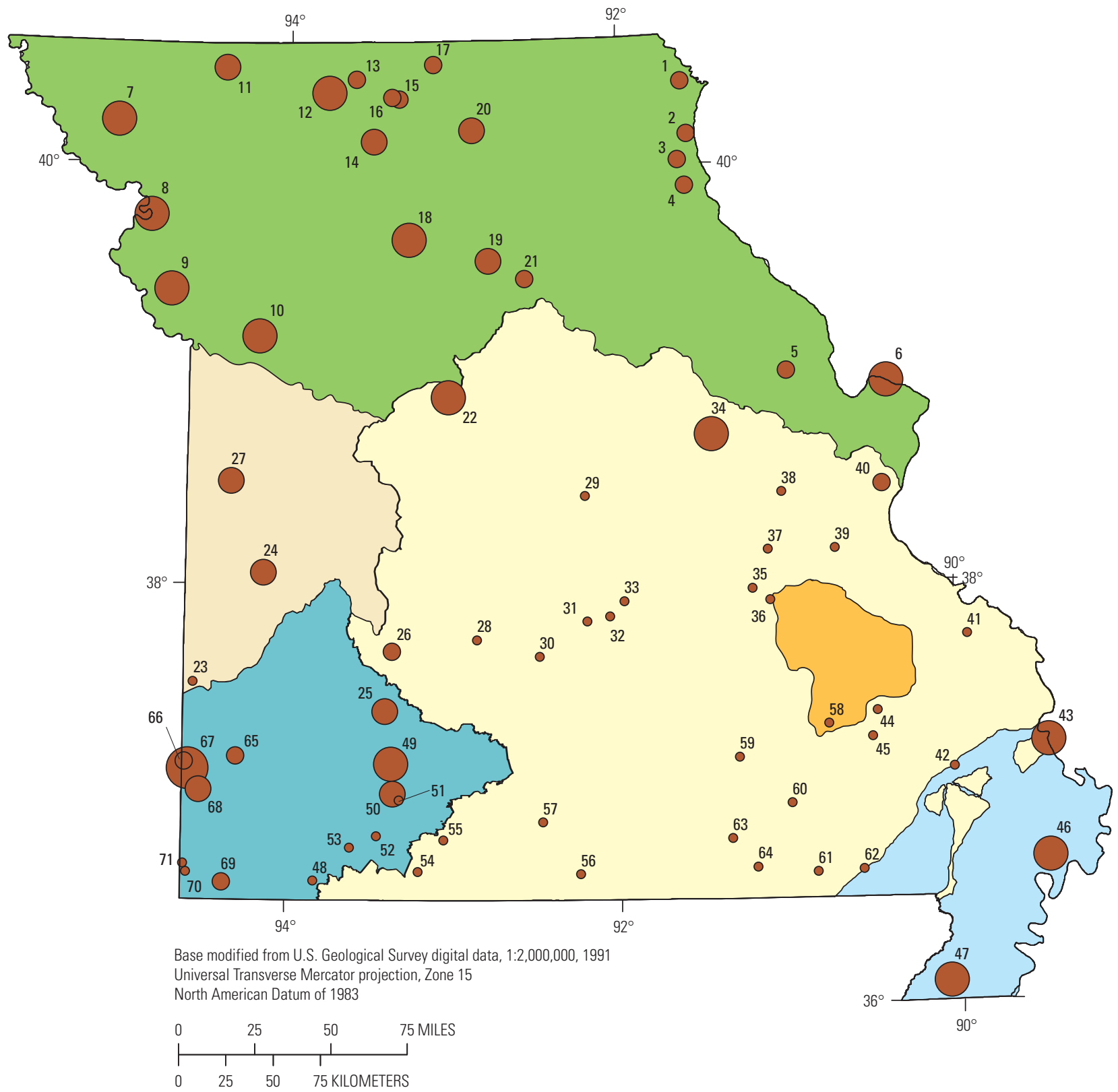

EXPLANATION

Physiographic regions-Modified from Fenneman, 1938

Concentration,

in milligrams per liter

Central Lowland Province-Dissected Till Plains

Central Lowland Province-Osage Plains

Coastal Plain Province-Mississippi Alluvial Plain

Ozark Plateaus Province-Salem Plateau

Ozark Plateaus Province-Springfield Plateau

St. Francois Mountains

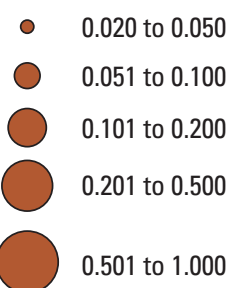

- $\quad 0.020$ to 0.050

0.101 to 0.200

0.501 to 1.000
0.051 to 0.100

Figure 9. Distribution of the median concentration of total phosphorus calculated for water years 1993 through 2017 at the Ambient Water-Quality Monitoring Network sites in Missouri. 
statistically significant trends (fig. 10, table 6). Because WT is not a mass-based measurement that R-QWTREND was primarily designed to analyze, it is not a parameter as suited to modeling as mass-based constituents, which also may account for the lower number of trends identified. Nine sites among six classes were identified as having statistically significant trends in WT. Most of the significant trends were among sites in the DTPL, the Ozark Plateaus Salem Plateau (OZPLSA), and the Ozark Plateaus Springfield Plateau (OZPLSP) classes. All significant trends were upward trends, except two: site 24 in the OSPL class and site 49 in the URBAN class. The WT trends reflect the general warm period that has occurred over the last 25 years (fig. 4). Most of the significant trends had a percent change in WT trend of about 10 percent or less during the trend period. The greatest percent change in trend was identified at site 24 in the OSPL class with about 23 percent change during the trend period.

Of 58 sites, 51 met the requirements necessary to be analyzed with R-QWTREND software for trends in DO. Trends in DO were significant at 13 sites among 5 classes (fig. 11, table 6). It should be noted that trends in DO may be affected by the normal diurnal fluctuation of the constituent, for which R-QWTREND does not account, and results should be used with some caution. The OZPLSA, OZPLSP, and URBAN classes had the most significant trends, of which most were downward. Two of the three sites in the URBAN class had the greatest percent change of DO trend during their analyzed periods among all sites, with site 49 having the greatest percent change, with about a 30 -percent decrease during the trend period, and site 67 having about a 20-percent increase. Two sites on the Missouri River also had significant trends - site 8 and 34. Site 8 had a two-period trend with the first period identified as a nonsignificant downward trend and the second period identified as a significant upward trend. Site 34 , downstream from site 8 , had a significant downward trend. Site 40, in the URBAN class, had a two-period trend with the first period identified as a significant downward trend and the second period identified as a significant upward trend.

Of 58 sites, 53 met the requirements necessary to be analyzed with R-QWTREND software for trends in SC. There were 16 statistically significant SC trends identified among sites, with more than one-half among sites within the OZPLSA and OZPLSP classes (fig. 12, table 6). Nearly every significant SC trend identified across all sites was upward except for two sites -52 and 67 , both within the URBAN class. Site 67 had a two-period SC trend with a significant upward trend followed by a significant downward trend in the second period. Most SC trends had a percent change of about 10 percent or less, except for sites 10 and 34 in the Big River class, site 22 in the OZPLSP class, and sites 52 and 67 in the URBAN class. Three of the five Big River sites had significant upward trends, with the greatest percent change in SC trend identified at site 10 at about a 40 -percent increase.

Of 58 sites, 53 met the requirements necessary to be analyzed with R-QWTREND software for trends in $\mathrm{pH}$. The number of statistically significant trends among the physical properties was highest for $\mathrm{pH}$ (fig. 13, table 6). However, a limitation on trends identified with R-QWTREND for $\mathrm{pH}$ is that it does not account for the fact that $\mathrm{pH}$ is expressed in logarithmic units, and results should be used with some caution. Of the 22 statistically significant trends identified, all were downward trends except three. There were 10 sites in the DTPL class with downward trends, of which 9 were identified as significant. The significant downward trends all had a percent change of about 8 percent or less. Three significant upward trends were identified in the OZPLSA and OZPLSP classes and all had an increase in concentration during the modeled period of about 5 percent or less. Only site 52 had a two-period trend identified as a best-fit model, which was significant and downward in the first period and nonsignificant and upward in the second.

\section{Nutrients}

Nutrients such as nitrogen and phosphorus are essential for plant and animal nutrition, but if excessive concentrations of nutrients are present in water bodies, the nutrients can cause water-quality concerns, such as algal blooms, fish kills, and taste and odor issues in drinking water sources. Some natural sources of nutrients are forest or other natural habitat runoff, soil erosion, and animal and plant decay. Nutrient sources from human activity can be caused by industrial or domestic waste discharges; sewage effluent; leaking septic tanks; urban runoff of residential or commercial areas (for example, parking lots) or fertilized grass areas (for example, golf courses, ball parks, or residential yards); and agricultural sources, such as runoff from row-crops with fertilizers, animal-grazed pasturelands, or improperly managed concentrated animal feeding operations (Barr and Davis, 2010). The nutrients selected for long-term trends among the AWQMN are NO3, TP, and DP. The selected nutrient constituents are nutrient forms most commonly present in natural waters, and NO3 and TP were part of the previous long-term trend investigation of six sites within the AWQMN (Barr and Davis, 2010).

Of 58 sites, 42 met the requirements necessary to be analyzed with R-QWTREND software for trends in NO3. A total of 14 statistically significant NO3 trends were observed at 13 sites - 10 upward and 4 downward (fig. 14, table 6).

Every class used in the study had a significant trend identified at one or more sites except in the OSPL and Spring classes. The significant upward trends generally increased by about 11 to 100 percent during the trend period, and downward trends all decreased by less than 35 percent during the trend period. Four of the five sites within the URBAN class had significant upward trends identified in NO3 concentrations, two of which (sites 40 and 67) were the greatest percent change of all significant trends increasing by about 100 percent. The range in annual geometric mean NO3 concentrations was small, typically less than $2 \mathrm{mg} / \mathrm{L}$ difference during the trend period for most sites except at sites 49 and 67. Annual geometric mean $\mathrm{NO} 3$ concentrations at site 49 increased from about $6 \mathrm{mg} / \mathrm{L}$ in 2009 to more than $22 \mathrm{mg} / \mathrm{L}$ in 2017; however, the trend 

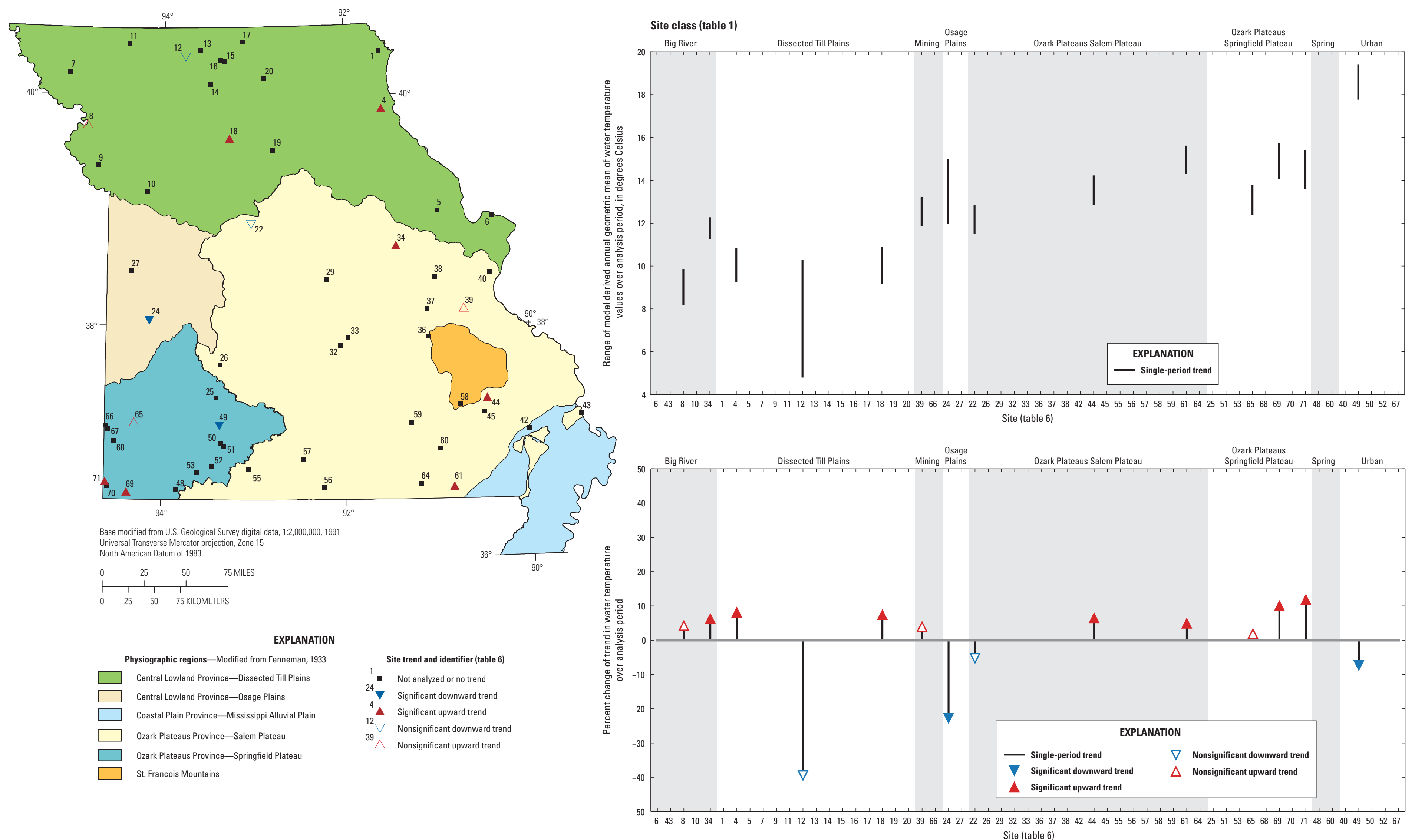

Figure 10. Water temperature trends for selected sites in the Missouri Ambient Water-Quality Monitoring Network (table 6). 

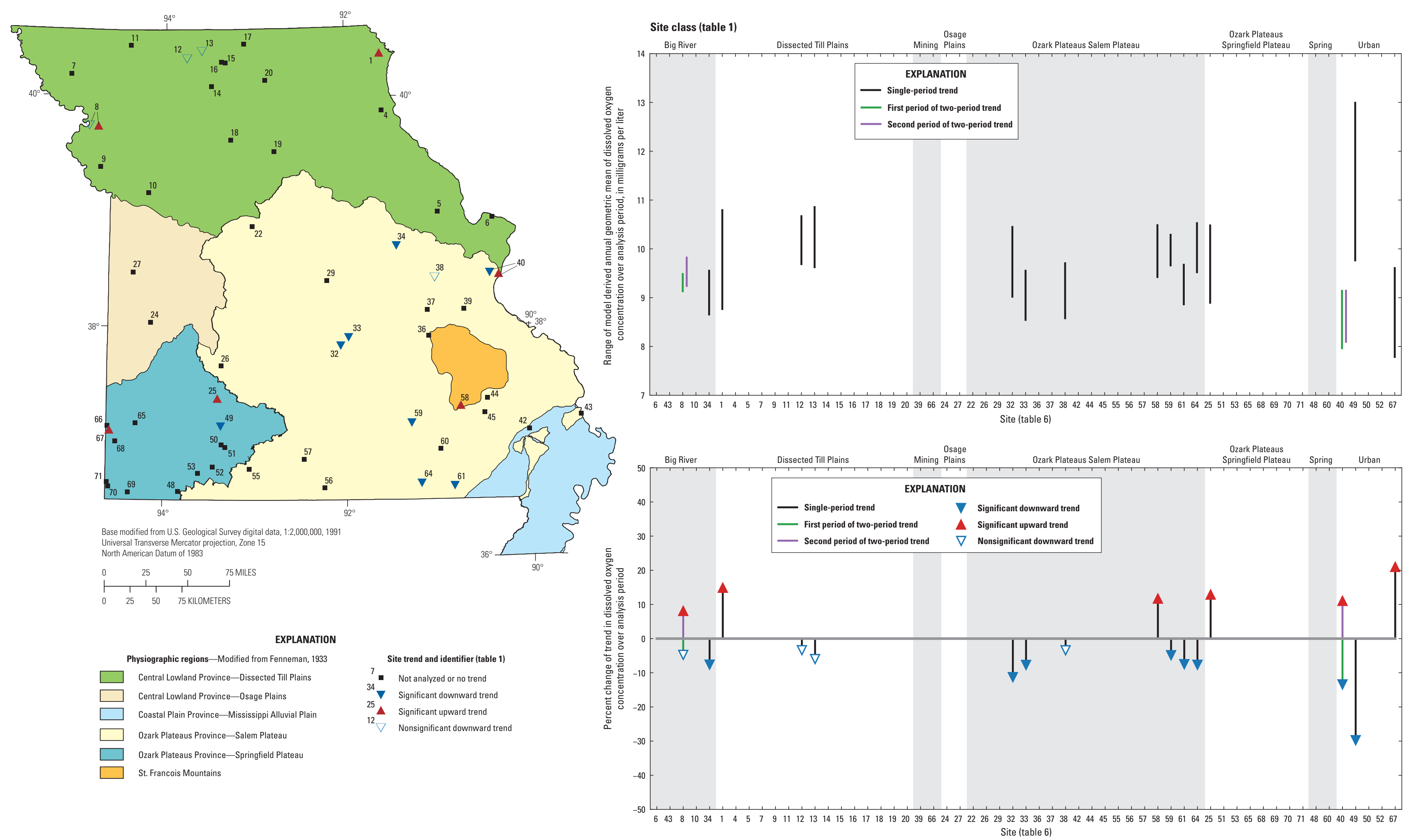

Figure 11. Dissolved oxygen trends for selected sites in the Missouri Ambient Water-Quality Monitoring Network (table 6). 

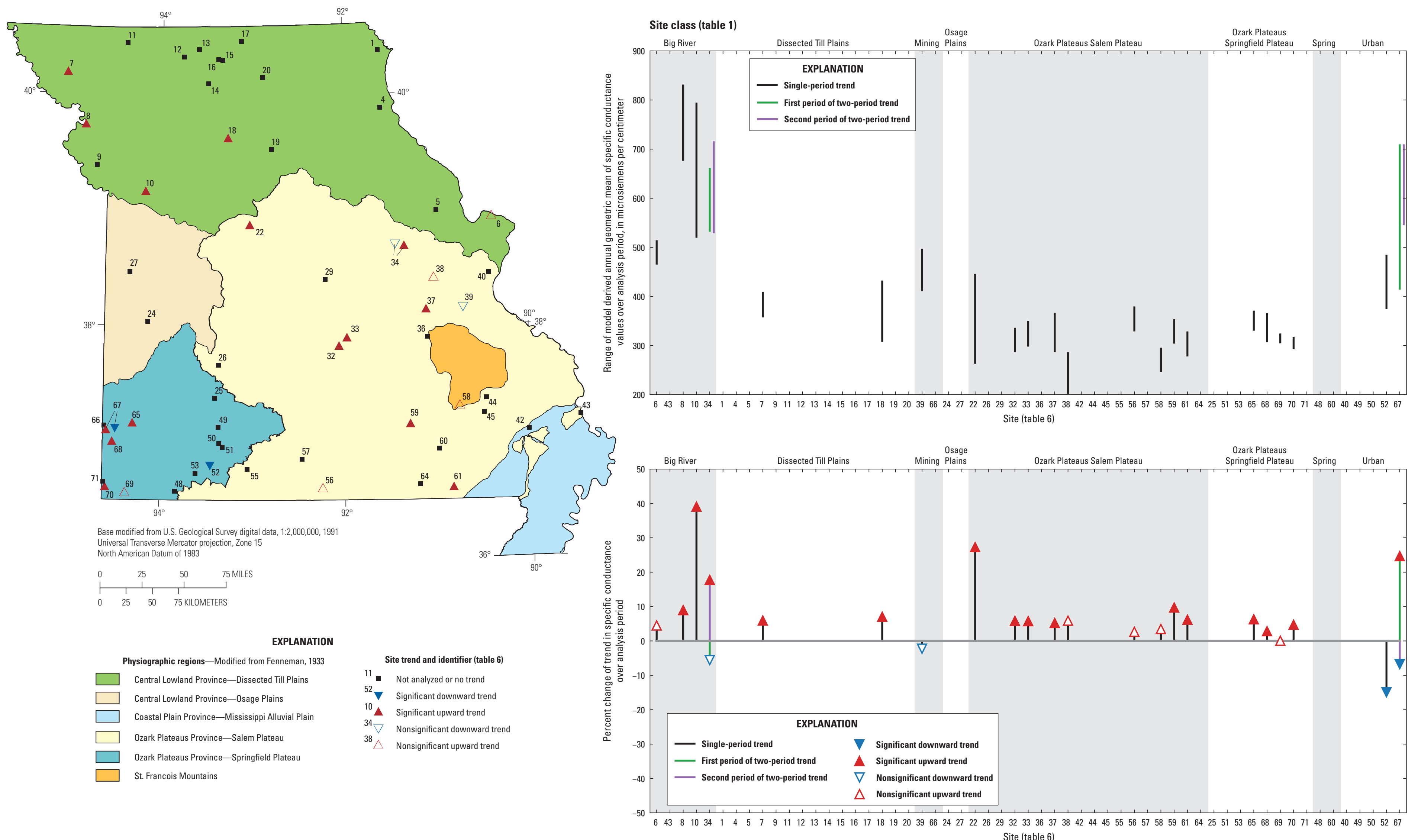

Figure 12. Specific conductance trends for selected sites in the Missouri Ambient Water-Quality Monitoring Network (table 6). 

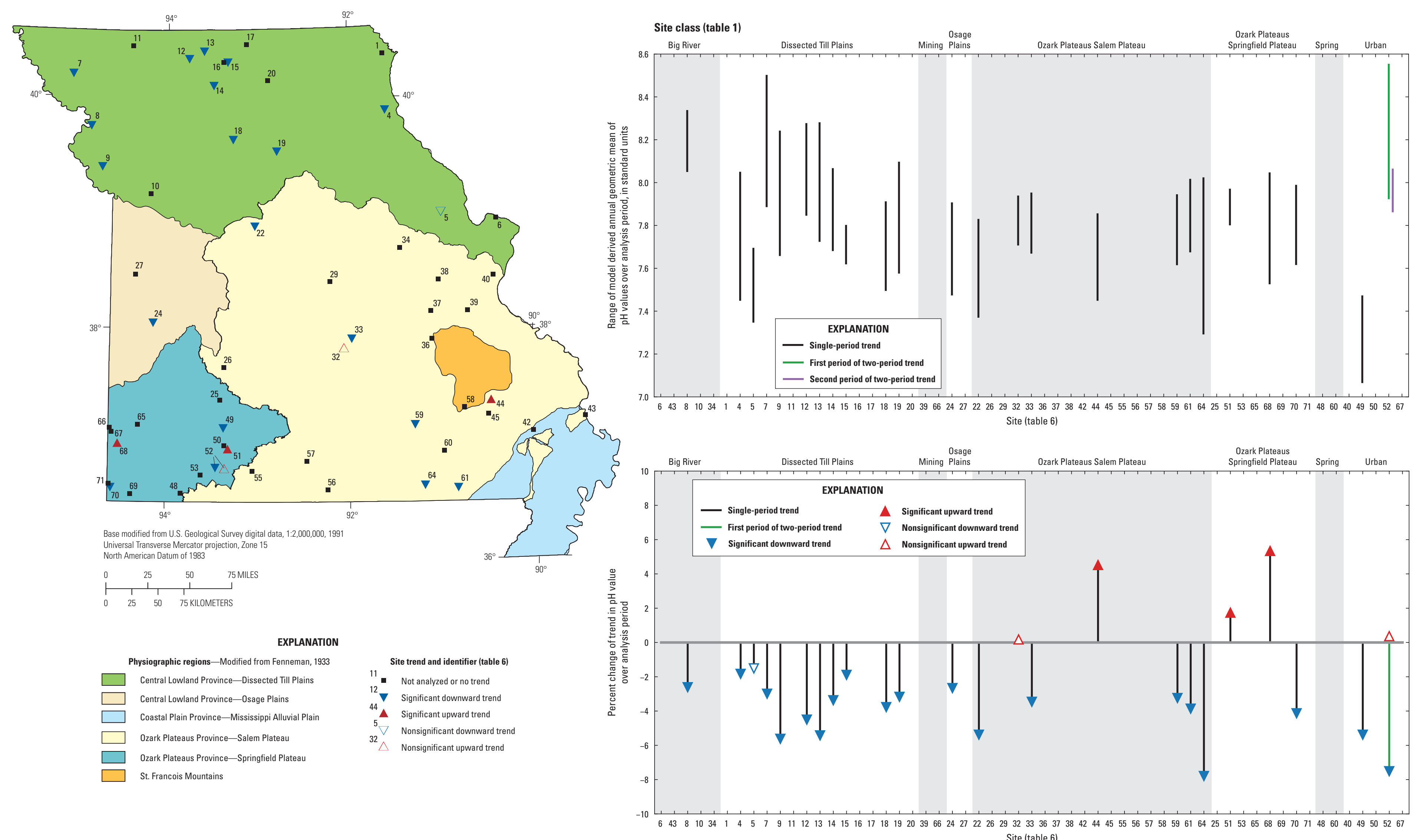

Figure 13. $\mathrm{pH}$ trends for selected sites in the Missouri Ambient Water-Quality Monitoring Network (table 6). 

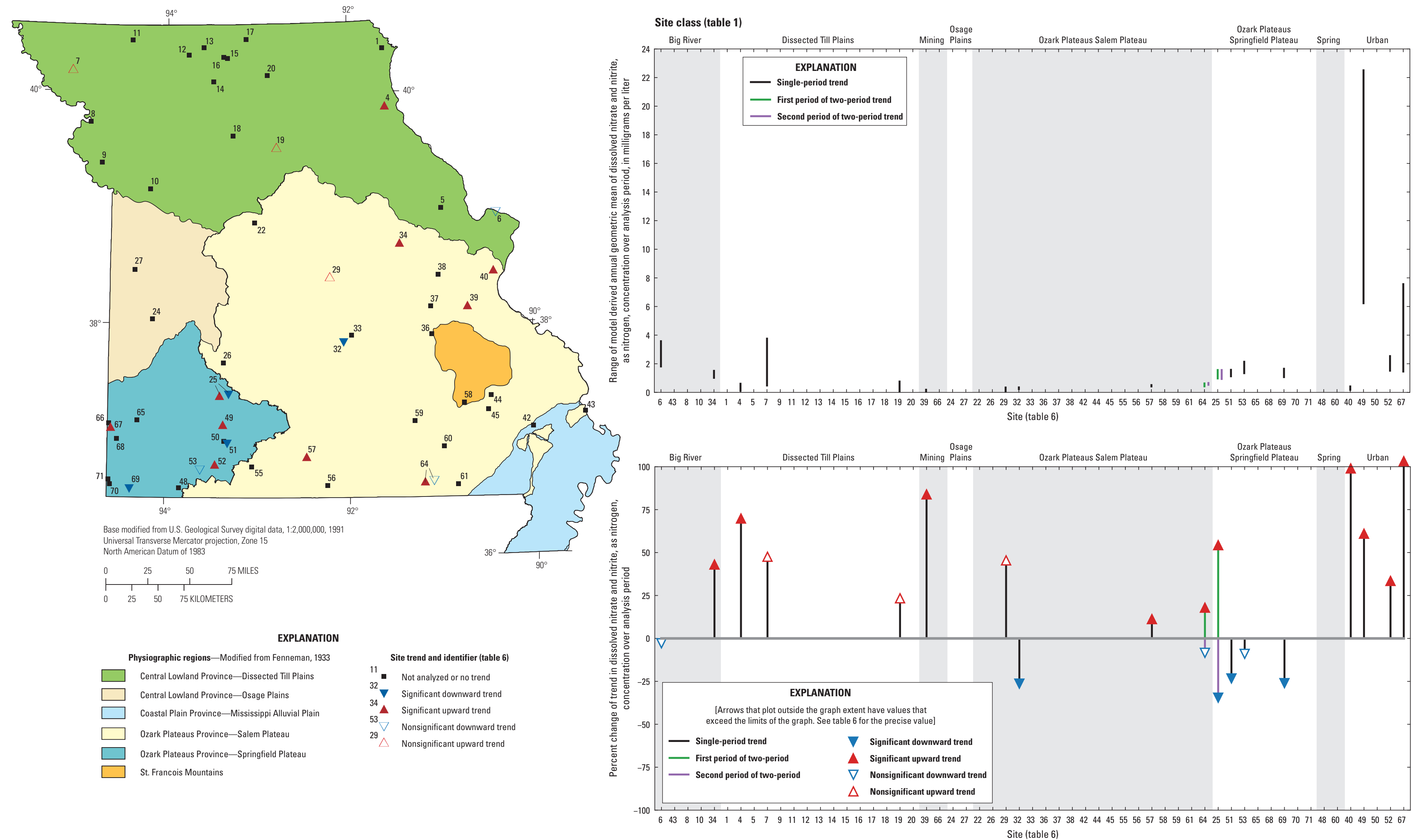

Figure 14. Dissolved nitrate plus nitrite, as nitrogen, trends for selected sites in the Missouri Ambient Water-Quality Monitoring Network (table 6). 
period was less than the ideal 10-year analysis period requirement and these results should be used with some caution. The annual geometric mean NO3 concentrations derived at site 67 increased from about $1.5 \mathrm{mg} / \mathrm{L}$ in 2000 to more than $6 \mathrm{mg} / \mathrm{L}$ in 2017. The upward trends in NO3 concentration, particularly among sites in the URBAN class during the study period, could be from increased urbanization in these watersheds, causing more nonpoint sources from runoff. Increases in NO3 concentrations identified among the other sites are located in basins with agricultural-dominated land uses.

Of 58 sites, 36 met the requirements necessary to be analyzed with R-QWTREND software for trends in TP. Statistically significant trends in TP concentrations were identified for 16 trend periods among 14 sites (fig. 15, table 6) with 7 upward and 9 downward trends. At least one significant trend was identified at sites among the eight classes except the MINING, SPRING, and OSPL classes. Sites in the northern half of the State had more significant upward trends than sites in the southern half. The upward significant trends TP identified at northern sites increased by about 40 to about 90 percent, and downward significant trends in the southern sites decreased by as much as about 84 percent to as little as 5 percent during the trend period. All significant upward trends were identified in northern sites except for site 43 (located on the Mississippi River in southeastern Missouri) and site 67 (an URBAN class site in southwest Missouri).

Five sites among the 14 sites with significant TP trends were identified as having two-period trends. All five sites had at least one significant period, and two sites (site 18 and 67) had significant trends in both periods. Four of the five sites with two-period trends are located in regions of agricultural land use in the DTPL (sites 4, 18, 19) and OZPLSA (site 22) classes. The first period of all five sites trended upward and the second trended downward, with all having a second period that started between 2005 and 2007. All five sites indicated significant downward trends in TP concentrations except site 19, which was downward yet not significant. Site 18 had a significant two-period trend with a large upward trend increasing nearly 90 percent in the first period (1993 through 2006), then decreasing by 30 percent in the second period (2006 through 2017). Site 67 also had a two-period trend; the first period (2000 through 2007) had an upward significant trend which increased by more than 100 percent (the greatest TP trend increase identified), and the second period (2007 through 2017) had a significant trend that decreased by about 50 percent. The range of annual geometric mean TP concentration at site 67 was the largest of all sites, particularly in the first period with an increase in annual geometric mean concentration of $0.294 \mathrm{mg} / \mathrm{L}$ in 2000 to $1.47 \mathrm{mg} / \mathrm{L}$ in 2007 . The annual geometric mean concentration decreased to $0.525 \mathrm{mg} / \mathrm{L}$ in 2017. Site 67 is the only URBAN site with a significant twoperiod TP trend, and it is noted the first period is less than the required 10 years so should be interpreted with caution. This site's basin is dominated by urban land use but also has other prominent land uses, such as pasture, forest, and row crops (fig. 3, table 2).
Of 58 sites, 21 met the requirements necessary to be analyzed with R-QWTREND software for trends in DP. Statistically significant trends identified in DP concentrations (12 trends at 10 sites; fig. 16, table 6) were fewer than the number of trends identified in TP concentrations (fig. 15), but still had similar trend directions between the northern sites (more upward trends) and southern sites (more downward trends). The same three Big River classified sites with statistically significant upward trends in TP concentrations also had significant upward trends in DP concentrations (sites 8, 34, and 43). Site 18 of the DTPL class, sites 69 and 70 of the OZPLSA class, and sites 49 and 67 of the URBAN class had similar trends in both DP and TP concentrations. As identified in the TP concentration trends, sites 18 and 67 had two-period trends with significant upward trends in the first period and significant downward trends in the second period. The trend at site 67 had the greatest increase of DP concentration of more than 100 percent, similar to the identified trend in TP concentration during the first period (2000-07). The greatest range of annual geometric mean DP concentration also was derived at site 67.

\section{Dissolved Chloride}

$\mathrm{Cl}$ can reach streams from various sources, such as salts that are applied to roadways during the winter for snow and ice removal, water treatments or softeners, sewage, and fertilizers (Kelly and others, 2010). In large concentrations, $\mathrm{Cl}$ can have a toxic effect on aquatic life and habitat and is used by the MDNR to determine exceedances to the State's waterquality standards for aquatic life protection.

Of 58 sites, 17 met the requirements necessary to be analyzed with R-QWTREND software for trends in Cl. Trends in $\mathrm{Cl}$ concentrations were statistically significant at 7 sites with 4 sites having upward and 3 sites having downward trends (fig. 17, table 6). Significant upward trends were identified at sites 6 and 43 on the Mississippi River (Big Rivers class), at site 18 (DTPL class), and site 40 (URBAN class). Site 40 had a two-period trend with the first period identified as a nonsignificant downward trend, and a significant upward trend during the second period increasing by about 40 percent from 2006 through 2017. The remaining three significant upward trends in $\mathrm{Cl}$ concentrations increased by about 20 to 25 percent during the full trend period. The sites with significant downward trends - sites 25, 37, and 52-are all located in the southern portion of the State. Sites 25 and 52 had the greatest percent decrease in $\mathrm{Cl}$ concentration (about 40 percent) while also having the greatest range in annual geometric mean concentrations of all seven sites with significant trends.

\section{Total Suspended Solids}

The MDNR uses TSS as a measurement of water quality for streams and lakes in the State. There is no numerical standard because each stream and lake have depositional differences, but the regulations documented in Missouri Department of Natural Resources (2019) indicate contaminants should not 

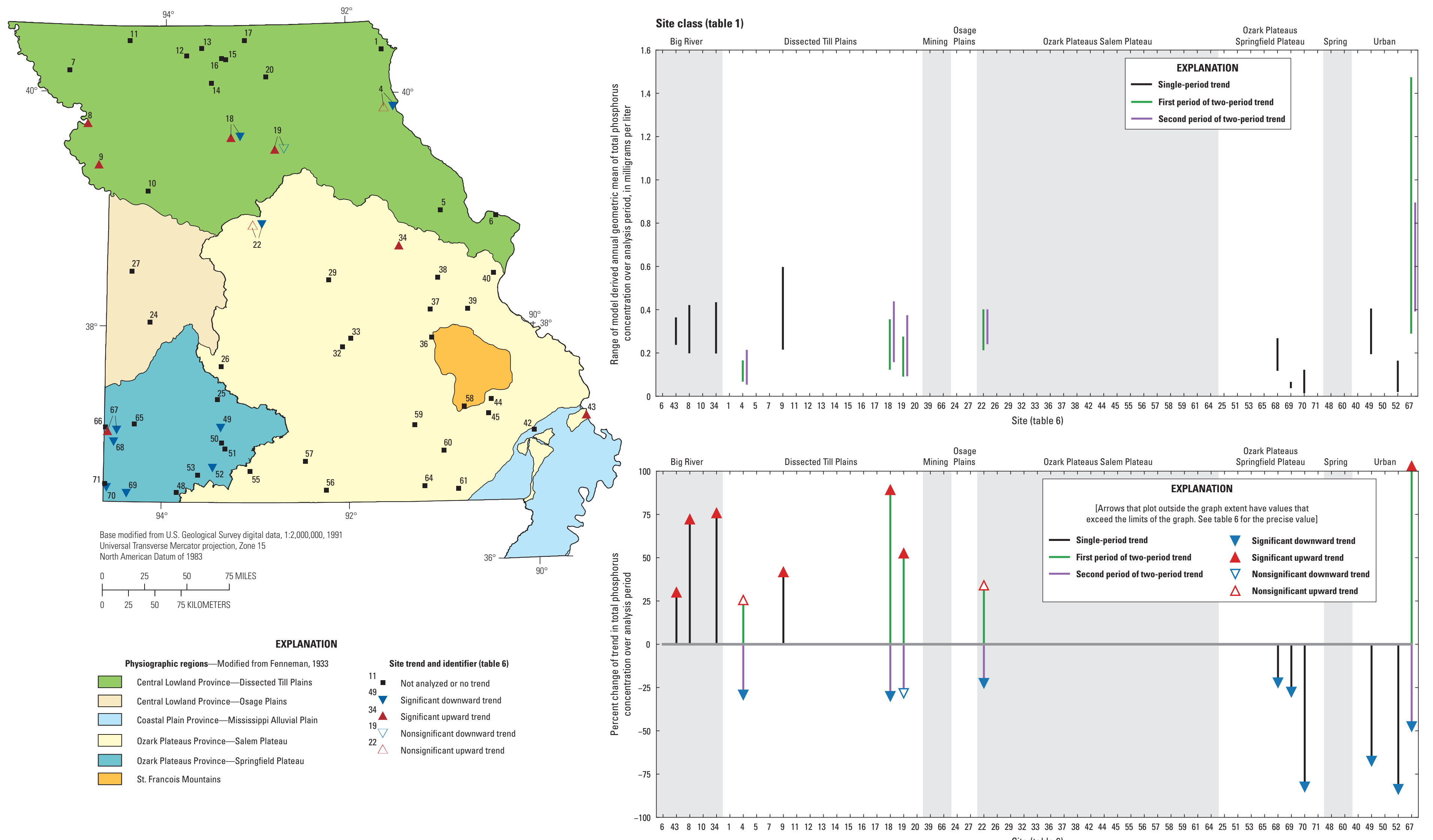

Figure 15. Total phosphorus trends for selected sites in the Missouri Ambient Water-Quality Monitoring Network (table 6). 
34 General Water-Quality Conditions, Long-Term Trends, and Network Analysis at Selected Sites, Water Years 1993-2017
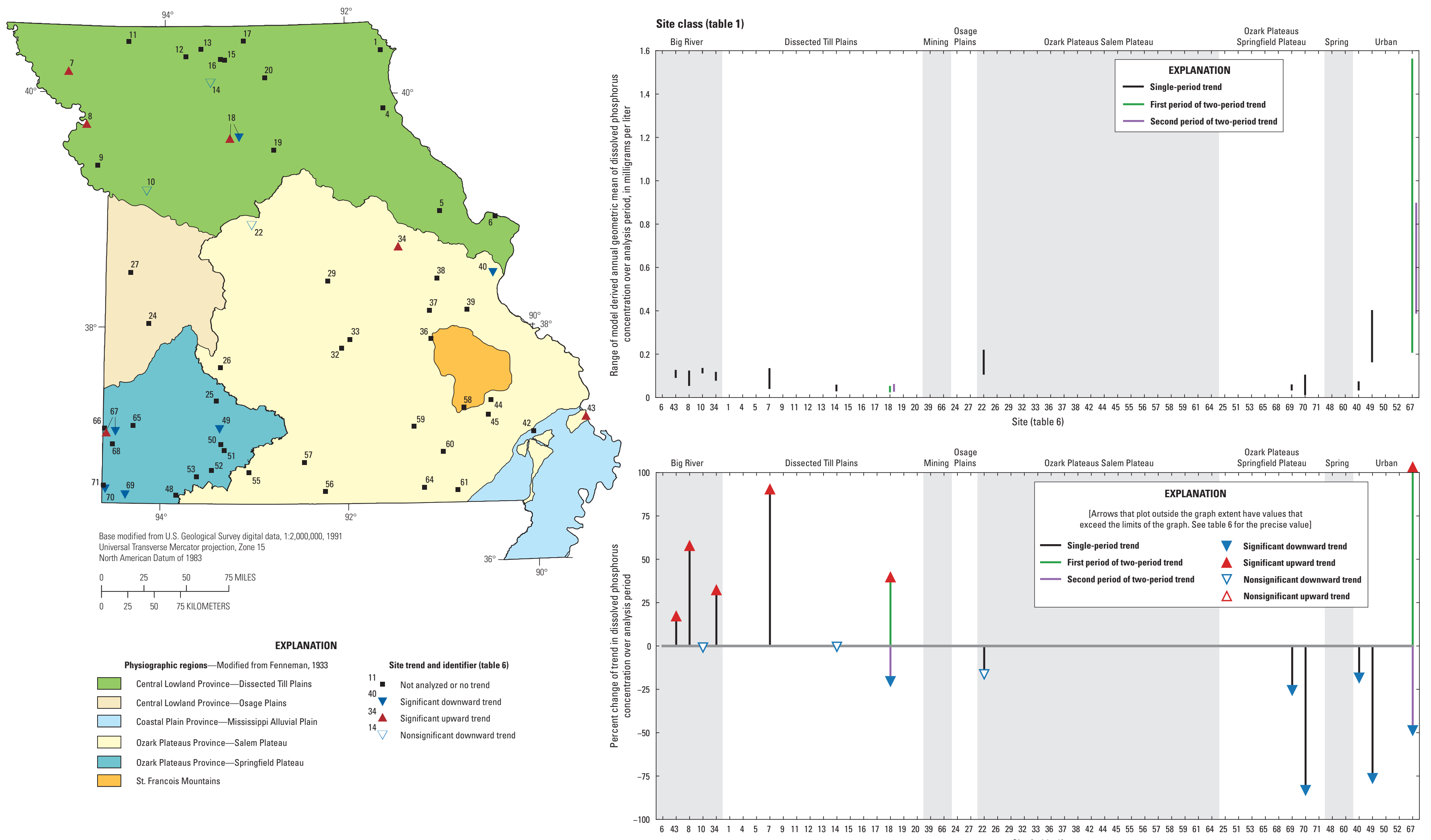

Figure 16. Dissolved phosphorus trends for selected sites in the Missouri Ambient Water-Quality Monitoring Network (table 6 f. 

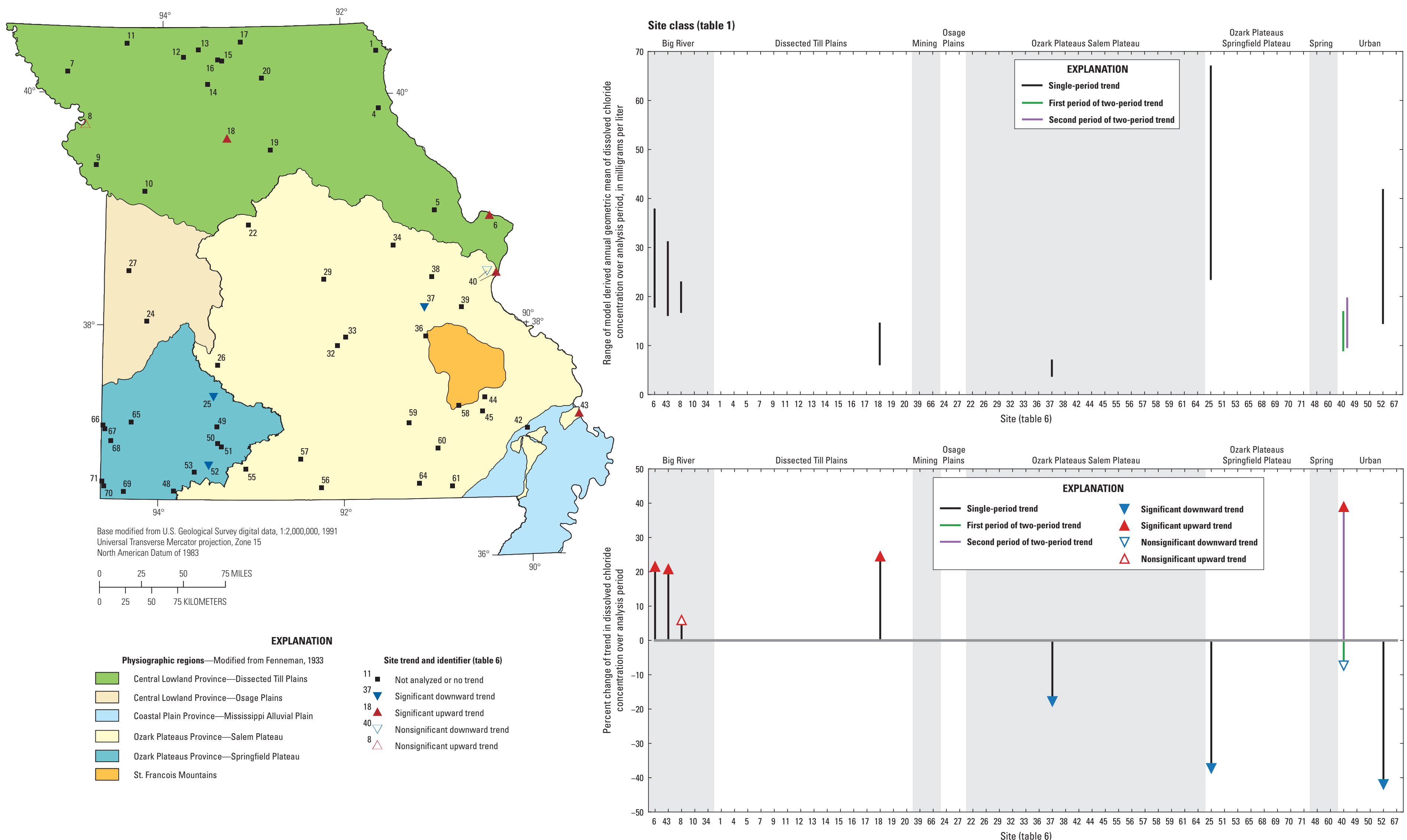

Figure 17. Dissolved chloride trends for selected sites in the Missouri Ambient Water-Quality Monitoring Network (table 6). 
contribute excess solids to a level that would interfere with beneficial uses or adversely alter the habitat of aquatic life. TSS concentration is the measurement of all solid particles in suspension during the time of collection, including organic material, and is often confused with suspended-sediment concentration measurements, which are a more accurate measure of material in suspension than TSS because of the sampling and analytical techniques used (Gray and others, 2000).

Of 58 sites, 11 met the requirements necessary to be analyzed with R-QWTREND software for trends in TSS. TSS results are highly variable and can be biased by precipitation and runoff. The measurement of TSS also is highly discharge dependent; therefore, results are commonly left-censored for most sites, especially at low discharge or base-flow conditions, resulting in few sites with datasets that did not exceed the limit of 25 percent censored data for reliable trends using R-QWTREND. In addition, TSS had a limited dataset because this constituent was not routinely collected within the AWQMN until 2000. The large amount of censored data and less available data for the study period resulted in statistically significant trends at only three sites (site 6,10, and 19), all of which were downward trends (fig. 18, table 6). Site 10 had the greatest decrease in percent change of concentration trend of about 70 percent.

\section{Fecal Indicator Bacteria}

Fecal indicator bacteria, such as FC and EC, are bacteria found in the intestines of warm-blooded animals and humans and may indicate the possible presence of disease-causing organisms. These bacteria are measured to indicate the possible human-health risks of fecal contamination in urban and rural streams. Some urban and rural sources of fecal indicator bacteria contamination include sewage overflows from older or failing infrastructure during heavy rainfall; improper connections between storm and sanitary sewer systems; leaking sanitary sewer lines and septic systems; and more traditional nonpoint sources, such as livestock, domestic animals, wildlife, and biosolid spreading as fertilizer on agricultural land (Bushon and others, 2017). In urban areas during rainfall, bacteria density can increase in surface waters through runoff from impervious surfaces, such as parking lots, roads, and roofs (Mallin and others, 2000).

Of 58 sites, 52 met the requirements necessary to be analyzed with R-QWTREND software for trends in FC. There were 14 statistically significant trends in FC population density among the study sites; 3 upward and 11 downward trends (fig. 19, table 6). The upward trends were at sites 37, 38, and 61 in the Salem Plateau in the southern part of the State. The FC density at these three sites increased from about 100 to 140 percent during the study period. In general, the range of geometric mean FC densities at sites in the southern part of the State where any trend (significant or nonsignificant) was identified, were considerably smaller than those in the north (fig. 19). Sites 7 and 18 of the DTPL class and site 8 of the Big Rivers class indicate a range in annual geometric mean of more than 800 colony forming units per 100 milliliters $(\mathrm{CFU} / 100 \mathrm{~mL})$ during the trend period at each site. Seven of the 11 single period downward trends were at sites in the northern part of the State among the Big Rivers and DTPL classes and one downward trend was in the Springfield Plateau (site 25). The downward trends among northern sites had FC density generally decreasing by about 70 percent or less during the trend periods.

Of 58 sites, 52 met the requirements necessary to be analyzed with R-QWTREND software for trends in EC. Similar to statistically significant fecal coliform population density trends, 13 statistically significant trends were identified in EC population density, and the direction of significant trends were mostly downward in northern sites and mostly upward in southern sites (fig. 20, table 6). Six sites in the northern portion of the State had significant trends: five downward at sites 10 and 34 (Big Rivers class) and sites 1, 5, and 15 (DTPL class); and one significant upward trend at site 12 (DTPL class). The significant trends in EC population densities decreased by about 60 to 65 percent at four sites, and by about 90 percent at site 10 . Site 10 also had the greatest range in annual geometric mean EC population density, with a maximum of more than $6,000 \mathrm{CFU} / 100 \mathrm{~mL}$ during the trend period. Although the upward trend in FC density at site 12 had the largest increase of about 700 percent, the range of annual geometric mean was small and only $46 \mathrm{CFU} / 100 \mathrm{~mL}$ in the starting year and $160 \mathrm{CFU} / 100 \mathrm{~mL}$ for the end year. This range does not indicate an extreme year within the period analyzed. Annual discharge-weighted mean concentrations and annual geometric mean concentration results derived by the model predictions at site 12 do not appear to be unusual or higher than other sites of similar basin size or in the same region. However, site 12 does not have a streamgage, and all discharge data used for the model predictions were estimated from a nearby streamgage location of similar basin size. It is possible that these estimated discharge data may have biased the discharge-weighted trend results for site 12 and therefore the trend results should be used with caution.

Statistically significant EC trends were identified at seven sites in the southern portion of the State. Significant upward trends were identified at five sites: site 32, 37, 55, 56, and 61, all within the OZPLSP class. Significant downward trends were identified at two sites: site 67 of the URBAN class, and site 43 of the Big Rivers class. The EC densities in the five significant upward trend sites increased more than 100 percent and site 61 had the greatest increase of about 240 percent. It is not evident in the results as to why the significant upward trends in EC population density had such extreme percent of change during the study period. The relation between the density and discharge may not correlate during times when there is possible runoff, creating an overestimated increase by the R-QWTREND program, because it is primarily designed to predict trends in mass-based constituents having units such as milligrams or micrograms per liter. 

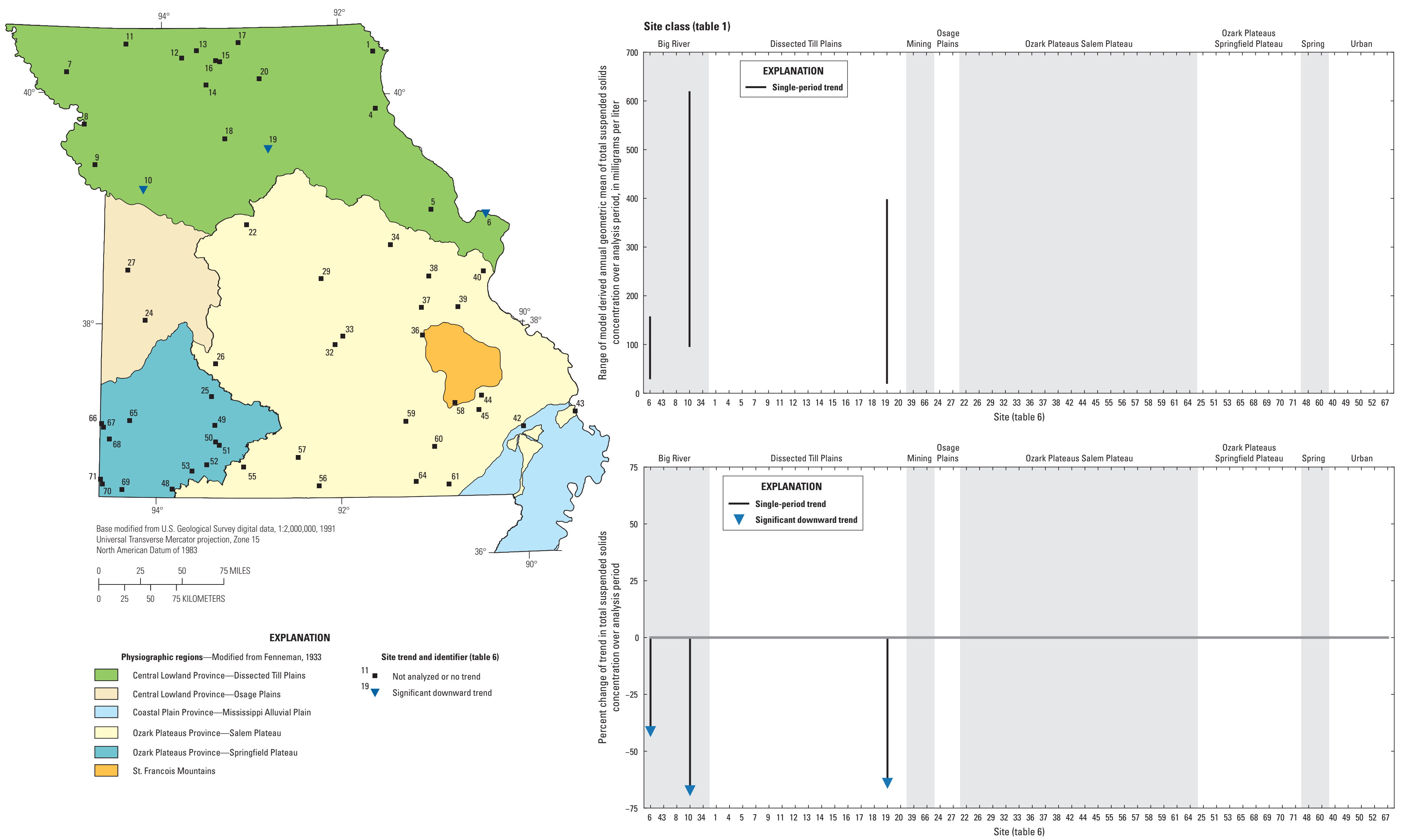

Figure 18. Total suspended solids trends for selected sites in the Missouri Ambient Water-Quality Monitoring Network (table 6). 
38 General Water-Quality Conditions, Long-Term Trends, and Network Analysis at Selected Sites, Water Years 1993-2017

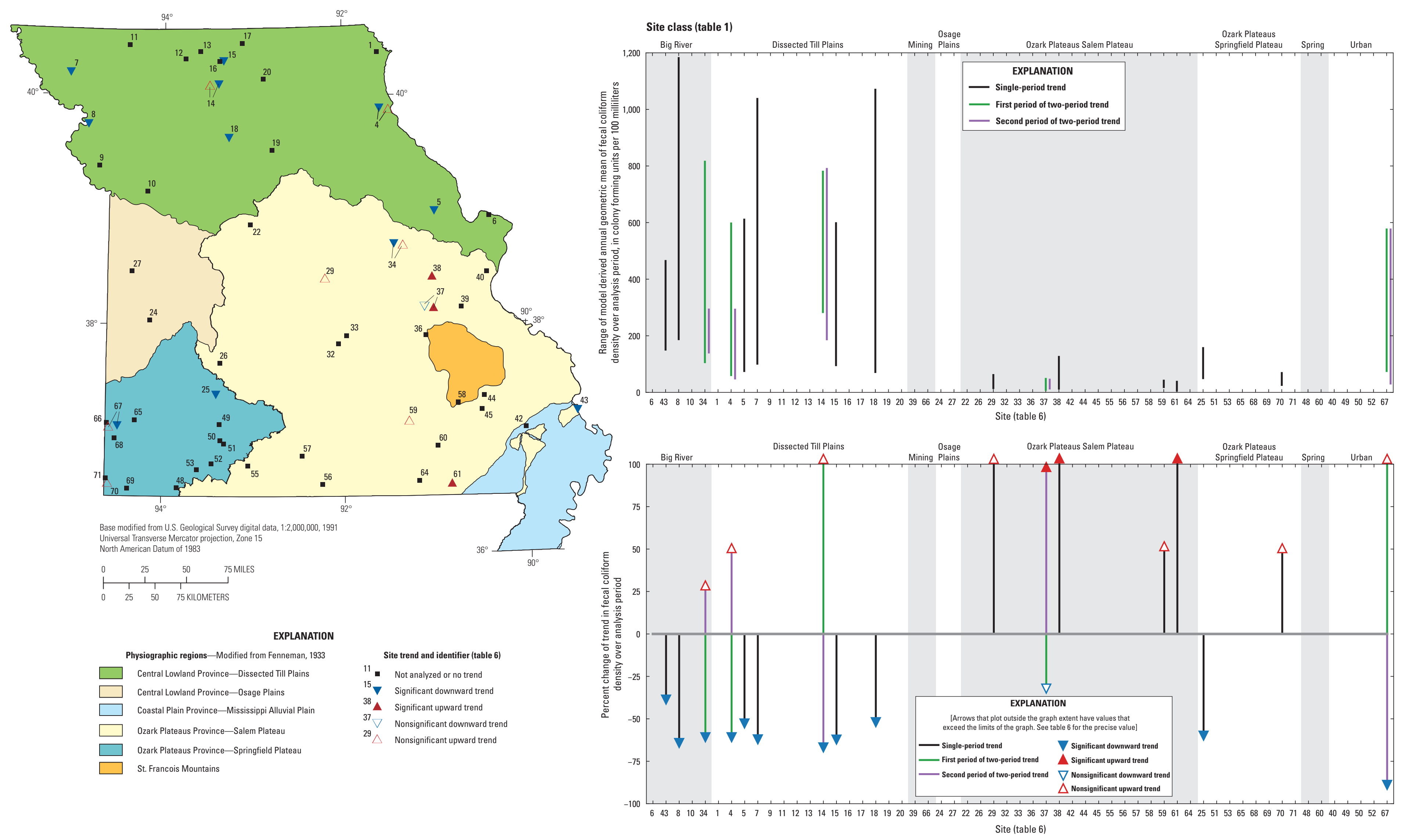

Figure 19. Fecal coliform trends for selected sites in the Missouri Ambient Water-Quality Monitoring Network (table 6). 


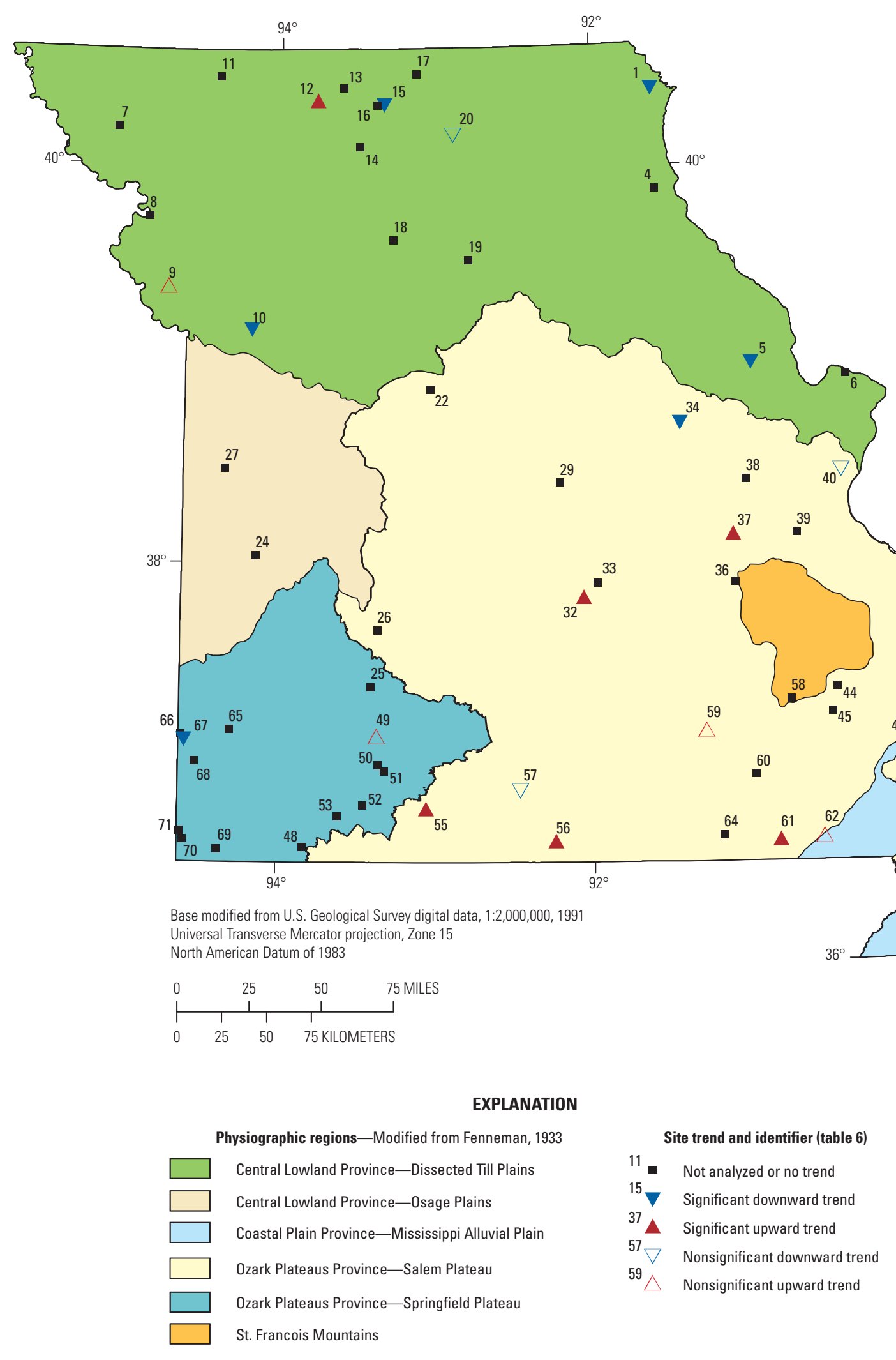

Site class (table 1)

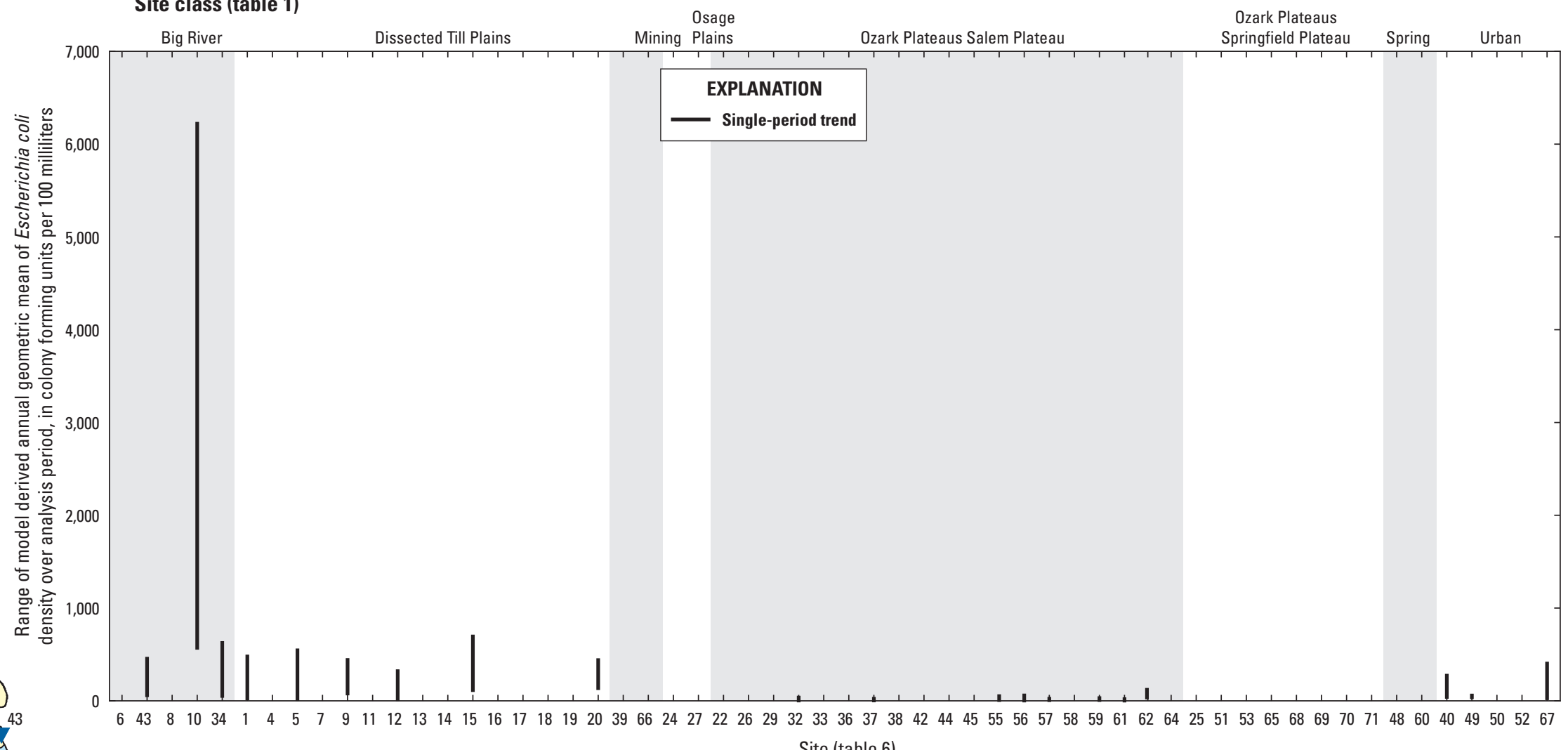
Site (table 6)

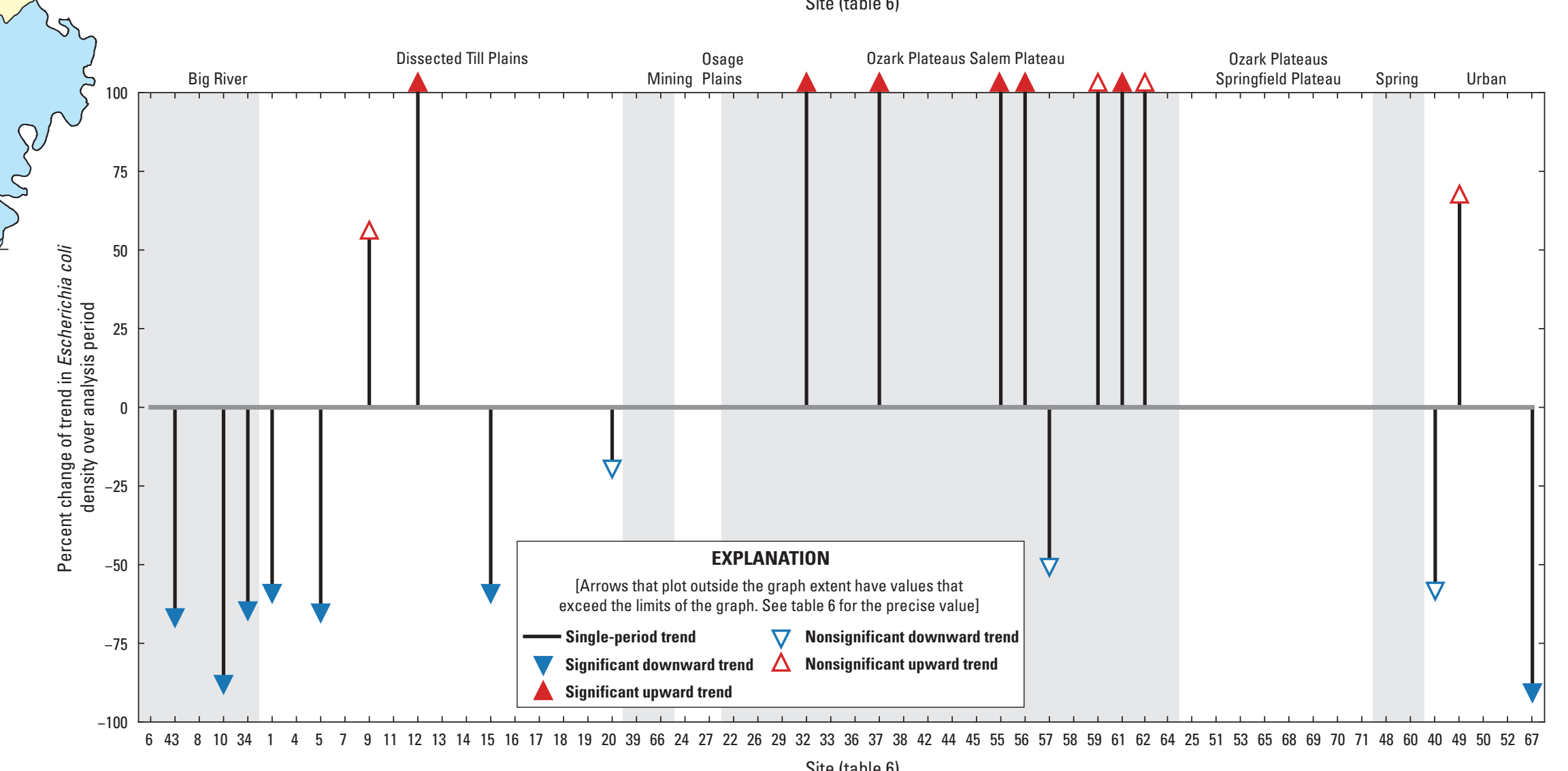

Figure 20. Escherichia colitrends for selected sites in the Missouri Ambient Water-Quality Monitoring Network (table 6). 
The MDNR monitors stream quality with stringent standards for fecal indicator bacteria on streams designated for recreational use. Many Missouri streams are designated as recreational use and fall into one of three categories: whole-body contact class A (WBC-A), whole-body contact class $\mathrm{B}$ (WBC-B), and secondary contact recreation (SCR). WBC-A recreation includes activities that involve full-body submergence into the water, whether intentional or accidental, creating internal exposure to the water through the eyes, ears, or nose; or by ingesting of water by swimming, water skiing, or skin diving (Missouri Department of Natural Resources, 2018a). WBC-B applies to waters used less frequently than WBC-A. The SCR uses include activities where only partial body submersion may occur and the risk of ingesting water, whether intentional or accidental, is minimal, such as fishing, boating, wading, shoreline activities, or other activities where users do not swim or float in the water (Missouri Department of Natural Resources, 2018a). These recreational use designations have water-quality standards for EC population densities that apply only to the recreational period of April 1 through October 31. Standards for EC were first implemented by MDNR in 2005. Prior to that, FC was used for the State standard. A stream is evaluated for its designated standard by computing a geometric mean of all samples collected at a site during the recreation period. $\mathrm{WBC}-\mathrm{A}$ criteria is $126 \mathrm{CFU} / 100$ $\mathrm{mL}, \mathrm{WBC}-\mathrm{B}$ is $206 \mathrm{CFU} / 100 \mathrm{~mL}$, and SCR is $1,134 \mathrm{CFU} / 100$ mL (Missouri Department of Natural Resources, 2018a).

All sites investigated in the study have been assigned a recreational use designated by the MDNR for whole-body contact standards. The 13 sites identified with a statistically significant trend in EC population densities have been listed in table 7 by their designated recreational uses. Six of the listed sites are designated with the highest level of recreational waters (WBC-A) and all but one had a significant upward trend in EC population densities during the study period. The remaining seven sites with significant EC population density trends are designated as WBC-B and all had downward trends except site 12 , which should be used with caution as possibly a biased trend resulting from the use of estimated discharge values.

\section{Trace Elements}

The trace elements lead and zinc (commonly referred to as trace metals) are naturally occurring elements within the Earth's crust and often are detected in surface waters (U.S. Geological Survey, 2019b). These same elements can be contaminants from point source pollution, such as wastewater treatment plants, or from mining related activities (U.S. Geological Survey, 2019b). Samples collected for the AWQMN are analyzed for a select suite of trace elements, which include $\mathrm{TPb}, \mathrm{DPb}, \mathrm{TZn}$, and DZn. These trace elements are analyzed on a fixed schedule about 2 to 4 times per year, depending on the total required number of samples per site.
The State standards for select trace elements vary with water hardness and the designated stream use (Missouri Department of Natural Resources, 2019).

$\mathrm{TPb}, \mathrm{DPb}, \mathrm{TZn}$, and DZn were analyzed for trends among the AWQMN sites, and TPb and TZn were analyzed for trends among NWQP sites. The selection of these trace elements was based on their inclusion in previous trend investigations (Barr and Davis, 2010) and the extensive historical mining of lead and zinc in Missouri (Missouri Department of Natural Resources, 2020). Because trace element analyses at AWQMN sites are few each year and results can be highly censored, many sites in the study did not have datasets that fit the minimum criteria for reliable trends (table 6).

Of 58 sites, $8(\mathrm{TPb}), 2(\mathrm{DPb}), 4(\mathrm{TZn})$, and 1 (DZn) site met the requirements necessary to be analyzed with $\mathrm{R}-$ QWTREND software for trends of trace metals. Statistically significant trends (all downward) were detected in $\mathrm{TPb}, \mathrm{DPb}$, $\mathrm{TZn}$, and DZn at one or more sites. No sites in the MINING class had significant trends in these metals. Downward trends were identified at two sites for DPb (fig. 21), at seven sites for $\mathrm{TPb}$ (fig. 22), at one site for DZn (fig. 23), and at two sites for TZn (fig. 24). The downward DPb trends were identified at site 25 of the OZPLSP class, and site 40 of the URBAN class. $\mathrm{DPb}$ concentrations at sites 25 and 40 similarly decreased by about 76 percent during the trend period, but the range in annual geometric means was greater at site 40, which was nearly twice the range derived at site 25 . Most of the identified $\mathrm{TPb}$ trends decreased by a mean of about 60 percent, with the greatest decrease in $\mathrm{TPb}$ concentration occurring at site 37 (about 78 percent) and the smallest decrease in $\mathrm{TPb}$ concentration occurring at site 40 (about 45 percent). Two sites (25 and 40) had significant trends in $\mathrm{DPb}$ and $\mathrm{TPb}$ with similar percent change in trends during the study period. Site 25 also had a significant downward trend of DZn concentration - with a decrease of about 70 percent during the study period. The TZn concentrations significantly decreased at site 18 of the DTPL class by about 55 percent, and at site 40 by about 50 percent.

Most of the sites identified for trends in the four trace element constituents are not located in areas known for lead mining in Missouri. Two sites (4 and 18) in the DTPL with primarily agricultural land use, two sites (37 and 38) in the OZPLSA class designated as recreational streams within mostly forested and agricultural land use, one site (25) in the OZPLSP class, and two sites (40 and 52) in the URBAN class had significant $\mathrm{TPb}$ concentration trends. Sites 18 and 40 had significant downward trends in $\mathrm{TPb}$ and $\mathrm{TZn}$ concentrations, and site 25 was identified for significant downward trends in $\mathrm{DPb}, \mathrm{DZn}$, and $\mathrm{TPb}$ concentrations. Site 40 is classified as URBAN but also is downstream from a large historical mining region. Sites 37 and 38 also are in a basin with some historical mining activity in the upper portions. It is possible some of the decreases in the trace element concentrations during the study period could be because of improved infrastructures, such as wastewater treatment plants, improved soil erosion and runoff 
Table 7. Escherichia coli population densities by geometric mean for recreational season (April through October) and median values computed from water sample results in comparison to State standards at study sites where a statistically significant trend was identified, January 1993 through December 2017.

[USGS, U.S. Geological Survey; CFU/100 mL, colony forming units per 100 milliliters; DTPL, Dissected Till Plains; WBC-B, whole-body contact category B; SCR, secondary contact recreational use; WBC-A, whole-body contact category A; Big Rivers, Missouri and Mississippi Rivers; OZPLSA, Ozark Plateaus Salem Plateau; OZPLSP, Ozark Plateaus Springfield Plateau; URBAN, urban]

\begin{tabular}{|c|c|c|c|c|c|c|c|c|c|c|}
\hline \multirow{2}{*}{$\begin{array}{c}\text { Study site } \\
\text { number (fig 1, } \\
\text { table 1) }\end{array}$} & \multirow{2}{*}{$\begin{array}{l}\text { USGS site } \\
\text { number }\end{array}$} & \multirow[t]{2}{*}{ Stream } & \multirow{2}{*}{$\begin{array}{c}\text { Site class } \\
\text { (table 1) }\end{array}$} & \multicolumn{2}{|c|}{$\begin{array}{l}\text { Recreation } \\
\text { designation }\end{array}$} & \multicolumn{2}{|c|}{$\begin{array}{l}\text { State standard } \\
\text { for designation }\end{array}$} & \multirow{2}{*}{$\begin{array}{l}\text { Geometric mean of } \\
\text { recreational season } \\
\text { (CFU/100 mL) }\end{array}$} & \multirow{2}{*}{$\begin{array}{c}\text { Median } \\
\text { (CFU/100 mL) }\end{array}$} & \multirow{2}{*}{$\begin{array}{l}\text { Statistically } \\
\text { significant } \\
\text { trend direction }\end{array}$} \\
\hline & & & & Primary & Secondary & Primary & Secondary & & & \\
\hline 1 & 05495000 & Fox River & DTPL & WBC-B & SCR & 206 & 1,134 & 238 & 100 & Down \\
\hline 5 & 05514500 & Cuivre River & DTPL & WBC-A & SCR & 126 & 1,134 & 115 & 48 & Down \\
\hline 10 & 06894100 & Missouri River & Big Rivers & WBC-B & SCR & 206 & 1,134 & 752 & 1,100 & Down \\
\hline 12 & 06898100 & $\begin{array}{l}\text { Thompson } \\
\text { River }\end{array}$ & DTPL & WBC-B & SCR & 206 & 1,134 & 339 & 120 & Up \\
\hline 15 & 06899950 & Medicine Creek & DTPL & WBC-B & SCR & 206 & 1,134 & 453 & 220 & Down \\
\hline 32 & 06930450 & $\begin{array}{l}\text { Gasconade } \\
\text { River }\end{array}$ & OZPLSA & WBC-A & SCR & 126 & 1,134 & 26 & 19 & Up \\
\hline 34 & 06934500 & Missouri River & Big Rivers & WBC-B & SCR & 206 & 1,134 & 189 & 160 & Down \\
\hline 37 & 07014500 & Meramec River & OZPLSA & WBC-A & SCR & 126 & 1,134 & 21 & 12 & Up \\
\hline 43 & 07022000 & $\begin{array}{l}\text { Mississippi } \\
\text { River }\end{array}$ & Big Rivers & WBC-B & SCR & 206 & 1,134 & 112 & 120 & Down \\
\hline 55 & 07053900 & Swan Creek & OZPLSP & WBC-A & SCR & 126 & 1,134 & 40 & 27 & Up \\
\hline 56 & 07057500 & $\begin{array}{l}\text { North Fork } \\
\text { River }\end{array}$ & OZPLSA & WBC-A & SCR & 126 & 1,134 & 19 & 13 & Up \\
\hline 61 & 07068000 & Current River & OZPLSA & WBC-A & SCR & 126 & 1,134 & 14 & 10 & Up \\
\hline 67 & 07186600 & Turkey Creek & URBAN & WBC-B & SCR & 206 & 1,134 & 66 & 47 & Down \\
\hline
\end{tabular}


42 General Water-Quality Conditions, Long-Term Trends, and Network Analysis at Selected Sites, Water Years 1993-2017
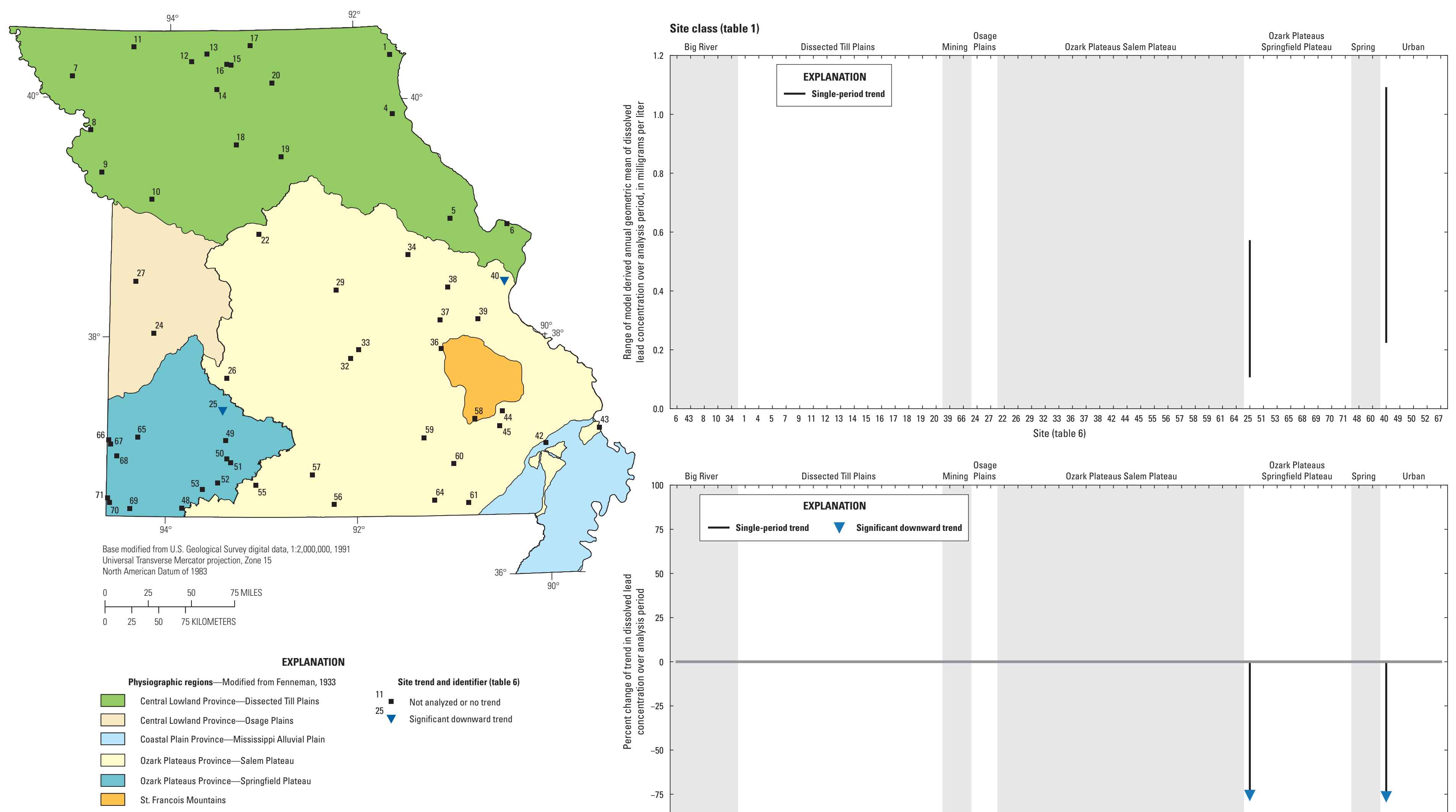

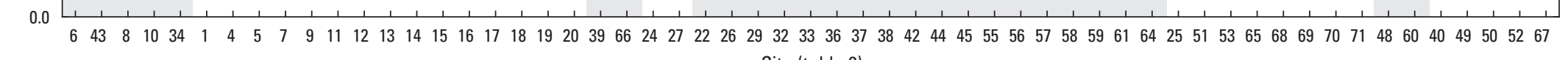

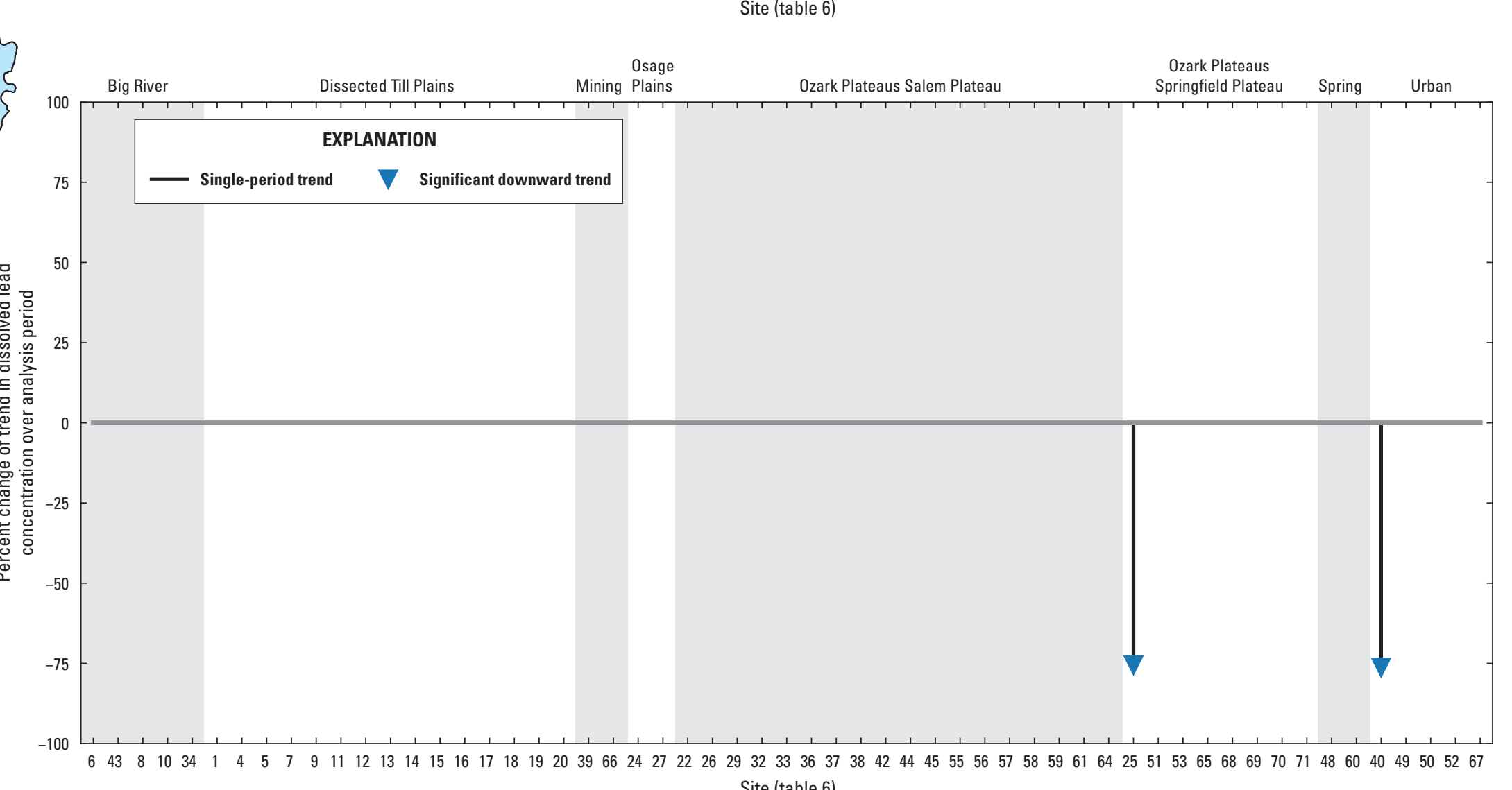
Site (table 6)

Figure 21. Dissolved lead trends for selected sites in the Missouri Ambient Water-Quality Monitoring Network (table 6). 

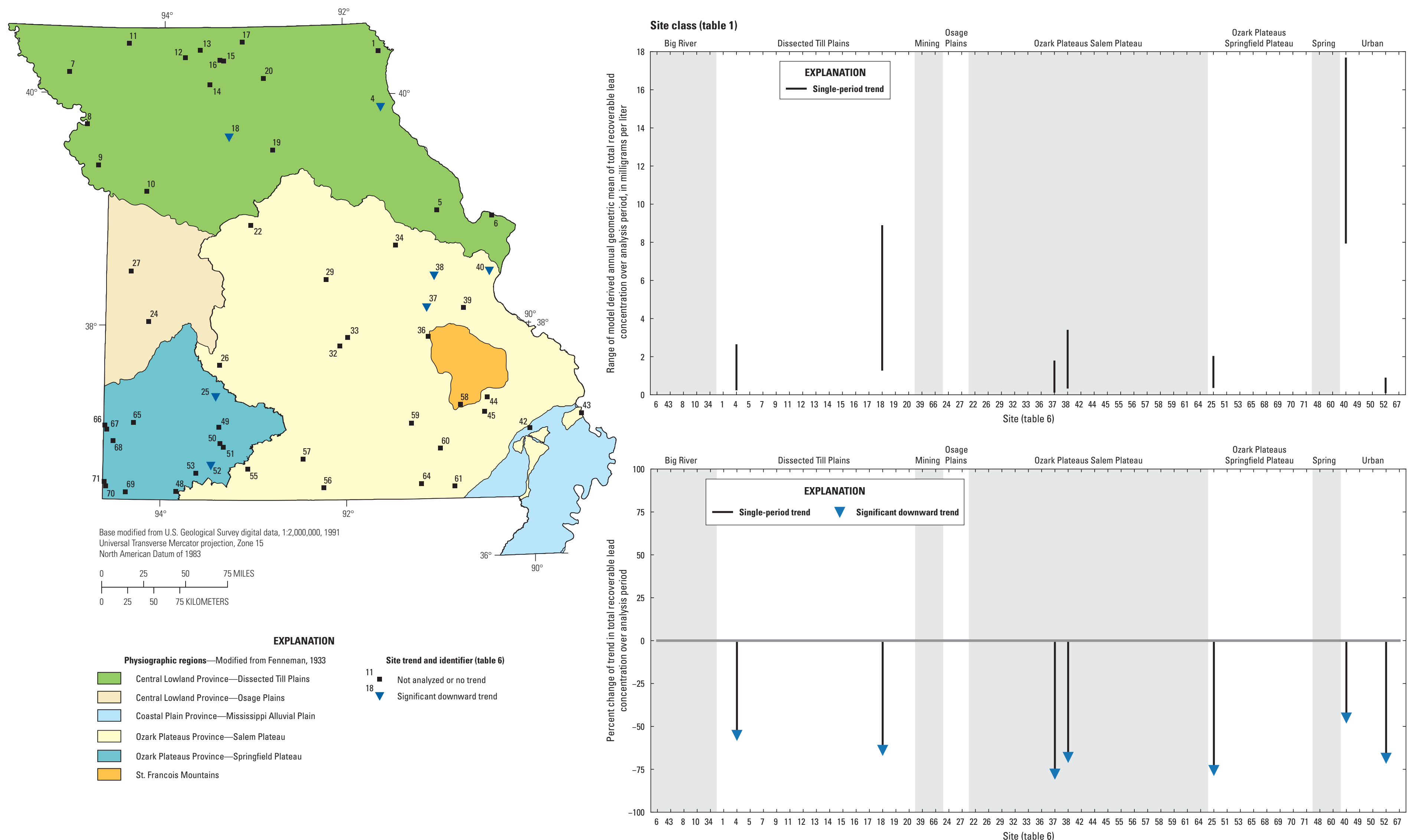

Figure 22. Total recoverable lead trends for selected sites in the Missouri Ambient Water-Quality Monitoring Network (table 6). 
44 General Water-Quality Conditions, Long-Term Trends, and Network Analysis at Selected Sites, Water Years 1993-2017
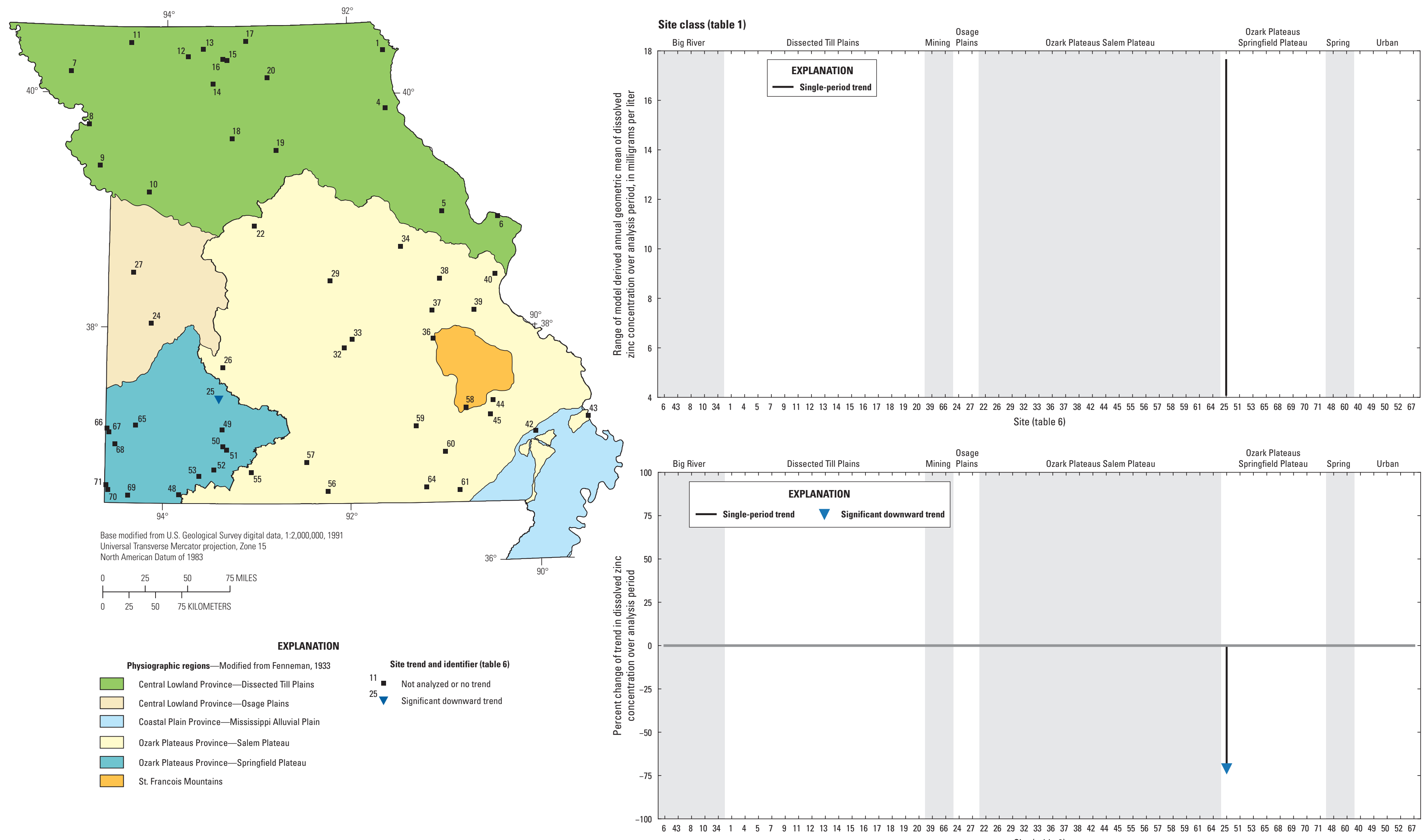

Figure 23. Dissolved zinc trends for selected sites in the Missouri Ambient Water-Quality Monitoring Network (table 6). 

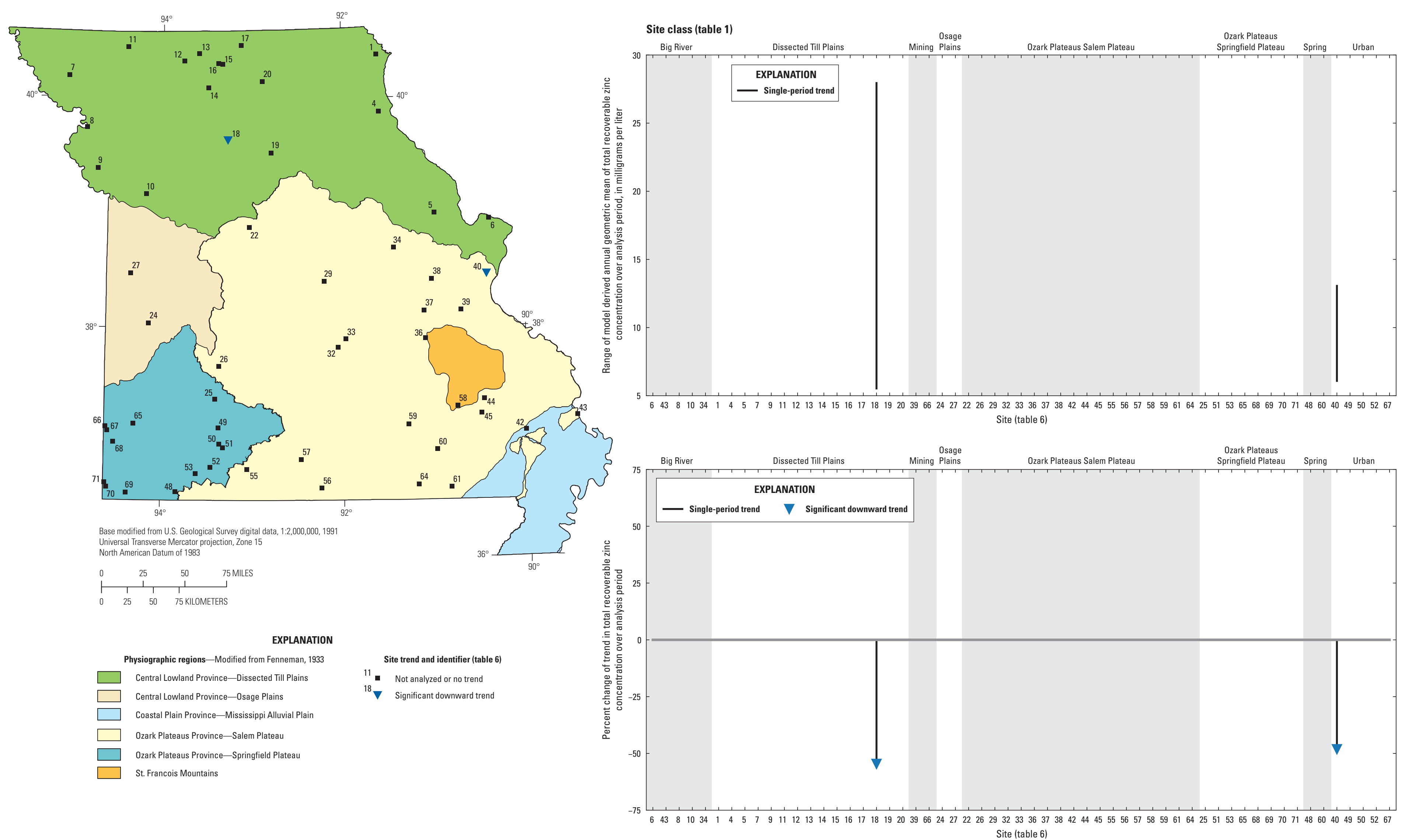

Figure 24. Total recoverable zinc trends for selected sites in the Missouri Ambient Water-Quality Monitoring Network (table 6). 
efforts in agricultural areas, improved containment of historical mining waste storage areas, reclamation efforts in upstream basin activities, or a combination of such events. It is also possible that some of the significant trends identified could be the result of false positives, a statistical consequence of the large number of statistical comparisons computed during this analysis.

\section{Other Trends and Analysis}

The Spearman's rank correlation coefficient was used to investigate if a monotonic function could describe the relation of the constituent concentration with time or discharge at 24 sites without continuous discharge. The possible relation between the water-quality constituent and time ( 24 sites, table 8 ) and the water-quality constituent and discharge (23 sites; site 54, a lake sampling site, had no discharge data and was not evaluated; table 9) was evaluated at each of the sites. In general, the strength of the monotonic relations between the water-quality constituents and discharge was greater than the relations between the water-quality constituents and time, with many more correlation coefficients that were moderately or strongly correlated for the discharge relations.
The results of the temporal analysis indicate that the constituents showing the most frequent (at seven or more sites) correlation of concentration with time, although mostly weakly correlated (correlation coefficient less than 0.4 ), were in SC (mostly positive trends), $\mathrm{pH}$ (mostly negative trends), WT (all positive trends), $\mathrm{Cl}$ (a mixture of positive and negative trends), and EC (mostly positive trends). Sites that had constituents that showed moderately temporally correlated trends were sites $12(\mathrm{pH}$, negative trend), $25(\mathrm{DPb}, \mathrm{TZn}$, and DZn; all negative trends), 46 ( $\mathrm{SC}$ and $\mathrm{Cl}$, positive trends; DP, negative trend), 66 (TZn, negative trend), and 67 (DPb, negative trend).

The results of the discharge analysis (table 9) indicate that the constituents having the most frequent correlation (greater than 10) were DO (mostly positive relations), SC (all negative relations), TP (mostly positive relations), $\mathrm{Cl}$ (all negative relations), EC (all positive relations), and $\mathrm{FC}$ (all positive relations). Sites 10, 11, 12, 13, 15, 16, 28, 31, 32, 36, 55,57 , and 66 showed strongly correlated relations in some constituents. Strongly correlated monotonic relations with discharge were present in SC, TSS, TP, Cl, and TPb. Sites 10, 47, and 66 had 10 or more significant relations in water-quality constituents that were indicated by the Spearman's rank correlation coefficient (table 9). 
Table 8. Analysis of the water-quality constituents versus time using the Spearman correlation coefficient and the $p$-value.

[Values shown in table are the Spearman correlation coefficient and are only shown where censored data made up less than 10 percent of all results and where the correlation was identified as significant ( $p$-value less than 0.05 ). All other values were not significant and are designated as "no data." DO, dissolved oxygen; SC, specific conductance; WT, water temperature; TSS, total suspended solids; NO3, dissolved nitrate plus nitrite, as nitrogen; DP, dissolved phosphorus; TP, total phosphorus; Cl, chloride; DPb, dissolved lead; TPb, total lead; DZn, dissolved zinc; TZn, total zinc; EC, Escherichia coli; FC, fecal coliform; --, no data]

\begin{tabular}{|c|c|c|c|c|c|c|c|c|c|c|c|c|c|c|c|}
\hline $\begin{array}{c}\text { Site (fig. 1, } \\
\text { table 1) }\end{array}$ & DO & SC & $\mathrm{pH}$ & WT & TSS & N03 & DP & TP & Cl & $\mathrm{DPb}$ & $\mathrm{TPb}$ & DZn & TZn & EC & FC \\
\hline 10 & -- & 0.328 & -- & -- & -- & 0.243 & -- & -- & -- & -- & -- & -- & -- & -- & -- \\
\hline 11 & -- & -0.266 & -0.322 & -- & -- & -- & -- & 0.272 & -- & -- & -- & -- & -- & -- & -- \\
\hline 12 & -- & -- & ${ }^{1}-0.441$ & -- & -- & -- & -- & -- & -- & -- & -- & -- & -- & 0.295 & -- \\
\hline 13 & -- & -- & -0.281 & -- & -- & -- & -- & -- & -- & -- & -- & -- & -- & 0.208 & -- \\
\hline 14 & -- & -- & -0.282 & -- & -- & -- & -- & -0.206 & -- & -- & -0.376 & -- & -- & -- & -0.197 \\
\hline 15 & -- & -- & -0.323 & -- & -- & -- & -- & -- & -- & -- & -- & -- & -- & 0.241 & 0.165 \\
\hline 16 & -- & -- & -0.181 & -- & -- & -- & -- & -- & 0.286 & -- & -- & -- & -- & -- & -- \\
\hline 17 & -- & -- & -0.171 & -- & -- & -- & -- & -- & -- & -- & -- & -- & -- & 0.156 & -- \\
\hline 20 & -- & -- & -0.255 & -- & -- & -- & -- & -- & -0.288 & -- & -- & -- & -- & -- & -- \\
\hline 22 & -0.206 & -- & -0.218 & 0.190 & -- & -- & -0.168 & -0.168 & -- & -- & -- & -- & -- & -- & -- \\
\hline 25 & -- & -0.350 & -- & -- & -- & -0.156 & -- & -- & -0.352 & ${ }^{1-0.550}$ & -- & ${ }^{1-0.544}$ & ${ }^{1-0.465}$ & -- & -- \\
\hline 28 & -0.169 & 0.208 & -0.240 & 0.205 & -- & -- & -- & -- & -- & -- & -- & -- & -- & 0.251 & 0.175 \\
\hline 30 & -- & -- & -- & -- & -- & -- & -- & -- & -- & -- & -- & -- & -- & -- & -- \\
\hline 31 & -0.173 & 0.182 & -0.208 & 0.227 & -- & -- & -- & -- & -- & -- & -- & -- & -- & -- & -- \\
\hline 32 & -0.305 & 0.152 & -- & 0.217 & -- & -0.291 & -- & -- & -- & -- & -- & -- & -- & 0.233 & -- \\
\hline 36 & -0.169 & 0.191 & -0.291 & -- & -- & -- & -- & -- & -0.367 & -- & -- & -- & -- & 0.252 & -- \\
\hline 46 & -- & ${ }^{1} 0.476$ & -- & 0.203 & -- & -- & $1-0.416$ & -0.237 & ${ }^{1} 0.472$ & -- & -- & -- & -- & -- & -- \\
\hline 47 & -- & -- & -- & -- & -- & -- & -- & -- & -- & -- & -- & -- & -- & -- & -- \\
\hline 54 & -- & -- & -0.264 & -- & -- & 0.339 & -- & -- & -- & -- & -- & -- & -- & -- & -- \\
\hline 55 & -- & -- & -- & -- & -- & -- & -- & -- & -0.259 & -- & -- & -- & -- & 0.194 & -- \\
\hline 57 & -- & 0.158 & -- & -- & -- & -- & -- & -- & -- & -- & -- & -- & -- & -- & -- \\
\hline 59 & -- & 0.323 & -0.177 & -- & -- & -- & -- & -- & -- & -- & -- & -- & -- & 0.249 & -- \\
\hline 66 & -0.211 & 0.157 & -- & 0.208 & -- & -0.150 & 0.187 & 0.205 & 0.396 & -- & -- & -0.304 & ${ }^{1}-0.510$ & -- & -- \\
\hline 67 & -- & -- & -- & 0.201 & -- & 0.232 & -0.275 & -0.270 & -- & $1-0.466$ & -0.372 & -- & -- & -0.221 & -0.282 \\
\hline
\end{tabular}

${ }^{1}$ Moderately correlated. 
[Values shown in table are the Spearman correlation coefficient and are only shown where censored data made up less than 10 percent of all results and where the correlation was identified as significant ( $p$-value less than 0.05). All other values were not significant and are designated as "no data." DO, dissolved oxygen; SC, specific conductance; WT, water temperature; TSS, total suspended solids; NO3, dissolved nitrate plus nitrite, as nitrogen; DP, dissolved phosphorus; TP, total phosphorus; Cl, chloride; DPb, dissolved lead; TPb, total lead; DZn, dissolved zinc; TZn, total zinc; EC, Escherichia coli; FC, fecal coliform; --, no data]

\begin{tabular}{|c|c|c|c|c|c|c|c|c|c|c|c|c|c|c|c|}
\hline $\begin{array}{c}\text { Site } \\
\text { (fig. 1, } \\
\text { table 1) }\end{array}$ & DO & SC & $\mathrm{pH}$ & WT & TSS & N03 & DP & TP & Cl & $\mathrm{DPb}$ & $\mathrm{TPb}$ & DZn & TZn & EC & FC \\
\hline 10 & $1-0.524$ & $1-0.694$ & -0.312 & 0.388 & ${ }^{2} 0.727$ & 0.317 & -- & ${ }^{1} 0.666$ & $2-0.760$ & -- & ${ }^{2} 0.709$ & -- & 0.699 & -- & -- \\
\hline 11 & -- & ${ }^{2}-0.709$ & -0.275 & -- & -- & -- & -- & ${ }^{2} 0.763$ & ${ }^{2}-0.734$ & -- & -- & -- & -- & ${ }^{1} 0.440$ & ${ }^{1} 0.432$ \\
\hline 12 & -0.263 & $1-0.680$ & -- & -- & -- & -- & -- & ${ }^{1} 0.649$ & ${ }^{2}-0.779$ & -- & -- & -- & -- & ${ }^{1} 0.531$ & ${ }^{1} 0.498$ \\
\hline 13 & -0.293 & ${ }^{1}-0.670$ & -- & -- & -- & -- & -- & -- & ${ }^{2}-0.745$ & -- & -- & -- & -- & ${ }^{1} 0.563$ & ${ }^{1} 0.547$ \\
\hline 14 & 0.192 & $1-0.696$ & -0.352 & -0.138 & -- & -- & -- & 0.170 & $1-0.470$ & -- & -- & -- & -- & -- & -- \\
\hline 15 & -- & ${ }^{2}-0.742$ & -- & -- & -- & -- & -- & ${ }^{2} 0.828$ & ${ }^{1}-0.669$ & -- & -- & -- & -- & ${ }^{1} 0.482$ & ${ }^{1} 0.451$ \\
\hline 16 & -- & ${ }^{2}-0.722$ & -- & -- & -- & -- & -- & ${ }^{2} 0.724$ & -- & -- & -- & -- & -- & ${ }^{1} 0.419$ & ${ }^{1} 0.403$ \\
\hline 17 & -- & $1-0.611$ & -0.300 & -- & -- & -- & -- & ${ }^{1} 0.642$ & -0.237 & -- & -- & -- & -- & ${ }^{1} 0.464$ & ${ }^{1} 0.488$ \\
\hline 20 & 0.297 & ${ }^{1}-0.680$ & -- & -- & -- & -- & -- & ${ }^{1} 0.453$ & ${ }^{1}-0.485$ & -- & -- & -- & -- & 0.340 & 0.319 \\
\hline 22 & -- & $1-0.523$ & $1-0.417$ & -- & -- & -- & -- & 0.168 & $1-0.661$ & -- & ${ }^{1} 0.670$ & -- & -- & ${ }^{1} 0.640$ & ${ }^{1} 0.598$ \\
\hline 25 & -- & ${ }^{1}-0.548$ & -- & -- & -- & -- & -- & -- & ${ }^{1}-0.462$ & -0.388 & -- & $1-0.481$ & $1-0.459$ & -- & -- \\
\hline 28 & -- & ${ }^{2}-0.788$ & -- & -0.163 & -- & -- & -- & -- & -- & -- & -- & -- & -- & ${ }^{1} 0.422$ & 0.342 \\
\hline 30 & -- & ${ }^{1}-0.673$ & -- & -- & -- & ${ }^{1} 0.612$ & -- & -- & ${ }^{1}-0.524$ & -- & ${ }^{1} 0.519$ & -- & -- & 0.281 & -- \\
\hline 31 & ${ }^{1} 0.454$ & ${ }^{2}-0.763$ & -- & ${ }^{1}-0.403$ & -- & -- & -- & -- & -- & -- & -- & -- & -- & 0.375 & 0.346 \\
\hline 32 & 0.185 & ${ }^{2}-0.820$ & -0.263 & -0.319 & -- & ${ }^{1} 0.436$ & -- & -- & -0.325 & -- & -- & -- & -- & ${ }^{1} 0.469$ & ${ }^{1} 0.476$ \\
\hline 36 & ${ }^{1} 0.448$ & ${ }^{2}-0.776$ & -- & $1-0.447$ & -- & 0.239 & -- & -- & $1-0.500$ & -- & -- & -- & -- & -- & -- \\
\hline 46 & -- & ${ }^{1-}-0.508$ & -0.259 & -0.235 & -- & 0.167 & -0.320 & 0.285 & $1-0.505$ & -- & -- & -- & -- & 0.399 & 0.276 \\
\hline 47 & 0.136 & ${ }^{1-0.690}$ & ${ }^{1-0.584}$ & -0.281 & ${ }^{1} 0.415$ & -- & 0.151 & ${ }^{1} 0.470$ & ${ }^{1}-0.653$ & -- & ${ }^{1} 0.439$ & -- & 0.373 & ${ }^{1} 0.486$ & ${ }^{1} 0.416$ \\
\hline 55 & 0.380 & ${ }^{2}-0.760$ & -- & $1-0.404$ & -- & ${ }^{1} 0.481$ & -- & -- & -0.281 & -- & -- & -- & -- & 0.224 & -- \\
\hline 57 & 0.209 & ${ }^{2}-0.855$ & -- & -0.270 & -- & -- & -- & -- & ${ }^{1}-0.421$ & -- & -- & -- & -- & 0.195 & -- \\
\hline 59 & -- & $1-0.451$ & -0.172 & -0.205 & -- & -- & -- & -- & $1-0.472$ & -- & -- & -- & -- & 0.355 & 0.265 \\
\hline 66 & -- & ${ }^{2-}-0.791$ & -0.342 & -0.180 & -- & -- & $1-0.505$ & -0.365 & ${ }^{2}-0.825$ & -- & ${ }^{1} 0.411$ & 0.300 & ${ }^{1} 0.420$ & 0.383 & ${ }^{1} 0.422$ \\
\hline 67 & -- & $1-0.542$ & -- & -- & -- & $1-0.610$ & $1-0.564$ & $1-0.566$ & ${ }^{1-0.538}$ & -- & 0.273 & -- & -- & -- & -- \\
\hline
\end{tabular}

${ }^{1}$ Moderately correlated.

${ }^{2}$ Strongly correlated. 


\section{Network Analysis}

Network analysis was done on the AWQMN sites in an attempt to evaluate if the data collected at AWQMN sites were representative of the range of data likely to be encountered at these sites and was designed to evaluate the relative sensitivity of selected sites and water-quality constituents to changes in data collection frequency. Network analysis also was used to determine if changes in data collection frequency at selected sites could reproduce the water-quality trends observed using the original dataset and to identify potential data gaps or redundancies in the network. Network analyses were intended to provide a framework to assist the managers to increase, reduce, reprioritize, change, and enhance the sites and data collected in the AWQMN to meet their future needs.

\section{Discharge Data Range Evaluation}

The purpose of evaluating the range of the sampled discharge to the full range of discharge potentially provides an indication of how the water-quality samples may represent the range of natural discharge conditions at the AWQMN sites. This type of analysis can be helpful for identifying those cases where the distribution of sampled discharges at a site does not adequately represent the distribution of the total population of daily mean discharges; as a consequence, the fluxes or trends estimated for constituents at those sites should be treated with caution. Comparisons were made between the sampled discharge and the continuous discharge distribution at the selected sites using graphical and statistical analysis to evaluate the adequacy of the water-quality sampling frequency with respect to the range of natural discharge conditions.

For the 47 AWQMN sites that had continuous discharge, boxplots were created and used to compare the distributions of the sampled discharge for each constituent to the daily mean discharge for the analysis period (Richards and Barr, 2021). For each site, many of the boxplots for the individual constituents are identical to one another. Because many of the constituents were sampled together, the distribution of the sampled discharge would be the same for these constituents. However, there are many cases in which the boxplots are not identical (fig. 25). The cases may include times when some constituents were not sampled with the same frequency as other constituents; when a constituent was omitted from a routine AWQMN sample because of a sampling or laboratory error, or because of a data quality issue; and occasionally, when special purpose water-quality samples were collected at some sites that may not have the same constituent list as the routine AWQMN samples.

If the sampling strategy for the water-quality samples were random (no particular discharge constraints) but temporally structured (monthly samples for example), then the two boxplots are expected to be very similar to each other, especially the median values and upper and lower quartiles. If the purpose of the sampling was to make accurate assessments of flux, then it is desirable that more emphasis be placed on collecting samples at high discharge because even small concentrations at high discharge can move large masses of a constituent. The ideal distribution for flux estimation would be when the lower quartile, median, and upper quartiles of the distribution of sampled discharges would all offset higher than the discharges in the full record for daily mean discharge (Hirsch and De Cicco, 2015). To provide a rich dataset that can be used to model the constituent concentrations and evaluate trends during the analysis period, a distribution that is similar to the daily mean discharge is desirable where the complete range (lower quartile; median; upper quartile; and to some extent, the data extremes) mimics the full record for daily mean discharge. For the 47 sites examined, the distribution of sampled discharge for most sites are similar to the distribution of the daily mean discharge. Few have the "ideal" flux estimation distribution. Some boxplots show sites having distributions that appear to be somewhat biased low where the lower quartile, median, and sometimes the upper quartile are lower than the full record for daily mean discharge. These distributions are mostly in plots of typically infrequently sampled constituents such as chloride, lead, and zinc. Sites such as site 23 (East Drywood Creek at Prairie State Park) are biased high because of the long periods of very low and zero discharge in the full record.

Statistical comparison of the data distributions shown in the boxplots using the two-sample KW and Kuiper tests were completed to determine if there were statistically significant differences in the sampled versus daily mean discharge distributions for each constituent at each site (table 10). The 47 continuous data sites were evaluated and ranked by summing the total number of significant differences (each two-sample KW or Kuiper test could add 1 to the total for each site-constituent pair for a total possible number of significant differences for each site of 32). Sites with the largest number of significant differences (in decreasing order) between the sampling and daily mean discharge data distributions were $23,6,34,43,24$, $69,8,7,37,50,48$, and 49 . The number of total significant differences for these 12 sites ranged from 1 (site 48 and 49) to 32 (site 23). Sites 23, 6, 34, and 43 had 22 or greater significant differences, whereas sites $24,69,8,7,37,50,48$, and 49 had 9 or fewer significant differences. The other 35 sites with continuous discharge data had no statistically significant differences between the sampling and daily mean discharge data distributions. Significant differences were also summed by constituent to provide an indication of which constituents (from the 12 sites with significant differences in discharge distribution) were the most likely to be underrepresented with respect to sampled discharge (table 11). The constituents with the largest number of significant differences (in decreasing order) between the sampling and daily mean discharge data distributions were TP, discharge, WT, $\mathrm{Cl}, \mathrm{FC}, \mathrm{pH}, \mathrm{DO}, \mathrm{NO}$, DP, SC, EC, DPb, DZn, TPb, TSS, and TZn. The number of total significant differences for these constituents ranged from 4 (TPb, TSS, and TZn) to $12(\mathrm{TP})$ at the 12 sites with significant differences in discharge distribution. 


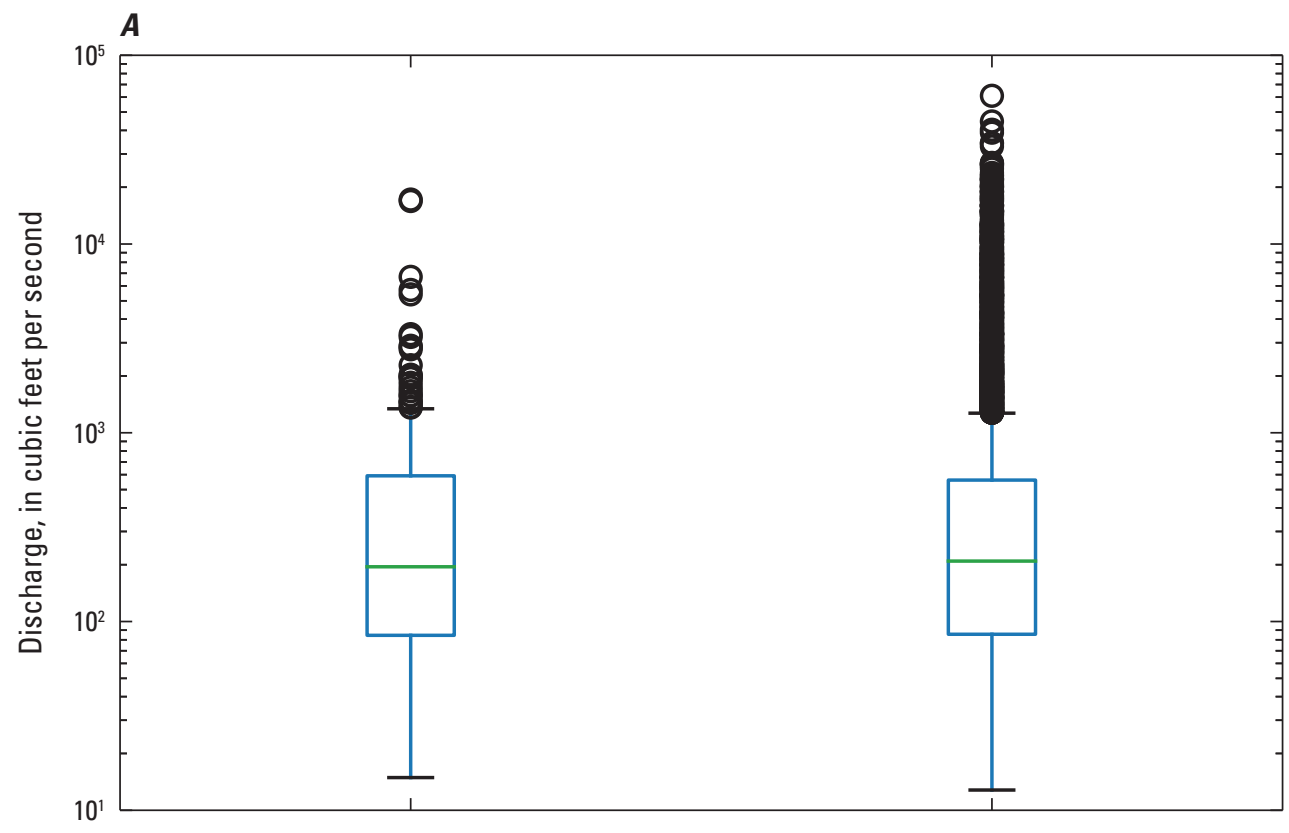

\section{EXPLANATION}

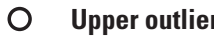

丁 Upper adjacent

75th percentile

Median

25th percentile

$\perp$ Lower adjacent

Lower outlier

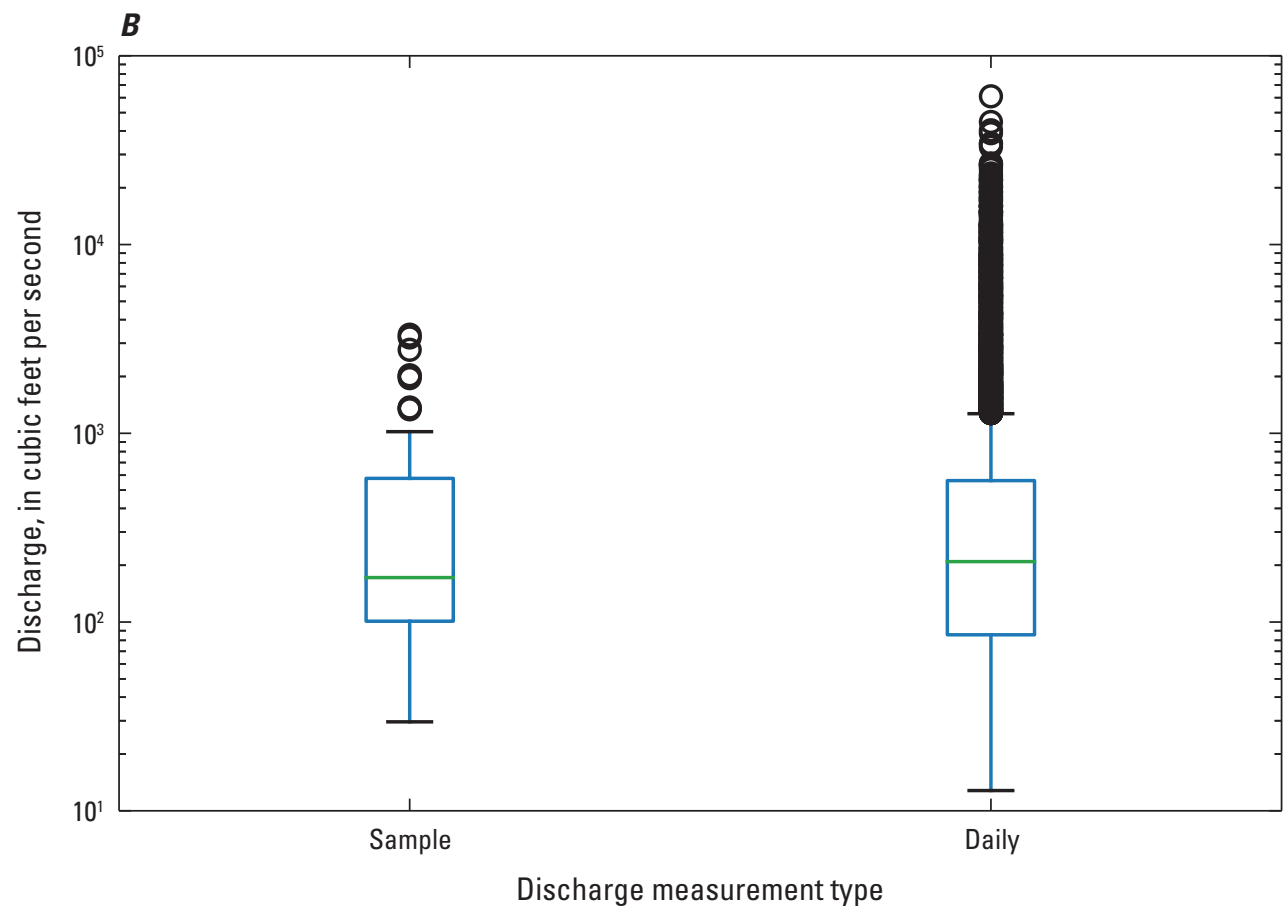

Figure 25. Example of different discharge distribution for two constituents at site 38 (U.S. Geological Survey streamgage 07016400, Bourbeuse River above Union, Missouri), that are sampled at a different frequency. $A$, Nitrate plus nitrite. $B$, Chloride.

To help understand whether the water-quality samples collected at each site generally represent the range of discharge conditions that existed during the period of analysis, minimum and maximum sampled discharges at each site were compared to the daily mean discharge record at the site during the period of analysis. The proportion of time at each site that the daily mean discharge was less than the minimum and greater than the maximum sample discharge was computed and is shown in table 12 . At site 23 , the daily mean discharge was less than the minimum sampled discharge for more than 38 percent of the discharge record, which is primarily because the site has a small drainage area and frequently goes dry for large parts of the period of record. The proportion of the daily mean discharge record where the daily mean discharge was greater than the maximum sampled discharge ranged from 0.01 percent (site 34 ) to 4.47 percent (site 2). Except for site 
Table 10. Number of significant differences indicated by the Kruskal-Wallace and Kuiper statistical tests for comparisons between sample discharge and daily mean discharge data distribution for each constituent at 47 Ambient Water-Quality Monitoring Network sites with continuous discharge data.

[Cl, dissolved chloride; FC, fecal coliform; DO, dissolved oxygen; EC, Escherichia coli; NO3, nitrate plus nitrite; DP, dissolved phosphorus; TP, total phosphorus; DPb, dissolved lead; TPb, total recoverable lead; Q, sample discharge; SC, specific conductance; TSS, total suspended solids; WT, temperature; DZn, dissolved zinc; TZn, total recoverable zinc; --, no data]

\begin{tabular}{|c|c|c|c|c|c|c|c|c|c|c|c|c|c|c|c|c|c|c|}
\hline $\begin{array}{c}\text { Site (fig. 1, } \\
\text { table 1) }\end{array}$ & Cl & FC & DO & EC & N03 & DP & TP & $\mathrm{DPb}$ & $\mathrm{TPb}$ & pH & 0 & SC & TSS & WT & DZn & TZn & $\begin{array}{c}\text { Total } \\
\text { significant } \\
\text { differences }\end{array}$ & $\begin{array}{c}\text { Rank of total } \\
\text { significant } \\
\text { differences }\end{array}$ \\
\hline 1 & 0 & 0 & 0 & 0 & 0 & 0 & 0 & 0 & 0 & 0 & 0 & 0 & 0 & 0 & 0 & 0 & 0 & 13 \\
\hline 2 & 0 & 0 & 0 & 0 & 0 & 0 & 0 & 0 & 0 & 0 & 0 & 0 & 0 & 0 & 0 & 0 & 0 & 13 \\
\hline 3 & 0 & 0 & 0 & 0 & 0 & 0 & 0 & 0 & 0 & 0 & 0 & 0 & 0 & 0 & 0 & 0 & 0 & 13 \\
\hline 4 & 0 & 0 & 0 & 0 & 0 & 0 & 0 & 0 & 0 & 0 & 0 & 0 & 0 & 0 & 0 & 0 & 0 & 13 \\
\hline 5 & 0 & 0 & 0 & 0 & 0 & 0 & 0 & 0 & 0 & 0 & 0 & 0 & 0 & 0 & 0 & 0 & 0 & 13 \\
\hline 6 & 2 & 2 & 2 & 0 & 2 & 2 & 2 & 2 & 1 & 2 & 2 & 2 & 0 & 2 & 2 & 1 & 26 & 2 \\
\hline 7 & 0 & 0 & 0 & 1 & 0 & 1 & 0 & 0 & 0 & 0 & 0 & 0 & 0 & 0 & 0 & 0 & 2 & 8 \\
\hline 8 & 0 & 0 & 0 & 0 & 0 & 0 & 0 & 0 & 0 & 0 & 2 & 0 & 0 & 2 & 0 & 0 & 4 & 7 \\
\hline 9 & 0 & 0 & 0 & 0 & 0 & 0 & 0 & 0 & 0 & 0 & 0 & 0 & 0 & 0 & 0 & 0 & 0 & 13 \\
\hline 18 & 0 & 0 & 0 & 0 & 0 & 0 & 0 & 0 & 0 & 0 & 0 & 0 & 0 & 0 & 0 & 0 & 0 & 13 \\
\hline 19 & 0 & 0 & 0 & 0 & 0 & 0 & 0 & 0 & 0 & 0 & 0 & 0 & 0 & 0 & 0 & 0 & 0 & 13 \\
\hline 21 & 0 & 0 & 0 & 0 & 0 & 0 & 0 & 0 & 0 & 0 & 0 & 0 & 0 & 0 & 0 & 0 & 0 & 13 \\
\hline 23 & 2 & 2 & 2 & 2 & 2 & 2 & 2 & 2 & 2 & 2 & 2 & 2 & 2 & 2 & 2 & 2 & 32 & 1 \\
\hline 24 & 0 & 1 & 1 & 0 & 1 & 1 & 1 & 0 & 0 & 1 & 1 & 1 & 0 & 1 & 0 & 0 & 9 & 5 \\
\hline 26 & 0 & 0 & 0 & 0 & 0 & 0 & 0 & 0 & 0 & 0 & 0 & 0 & 0 & 0 & 0 & 0 & 0 & 13 \\
\hline 27 & 0 & 0 & 0 & 0 & 0 & 0 & 0 & 0 & 0 & 0 & 0 & 0 & 0 & 0 & 0 & 0 & 0 & 13 \\
\hline 29 & 0 & 0 & 0 & 0 & 0 & 0 & 0 & 0 & 0 & 0 & 0 & 0 & 0 & 0 & 0 & 0 & 0 & 13 \\
\hline 33 & 0 & 0 & 0 & 0 & 0 & 0 & 0 & 0 & 0 & 0 & 0 & 0 & 0 & 0 & 0 & 0 & 0 & 13 \\
\hline 34 & 2 & 2 & 2 & 2 & 2 & 2 & 2 & 1 & -- & 2 & 2 & 2 & -- & 2 & 1 & -- & 24 & 3 \\
\hline 35 & 0 & 0 & 0 & 0 & 0 & 0 & 0 & 0 & 0 & 0 & 0 & 0 & 0 & 0 & 0 & 0 & 0 & 13 \\
\hline 37 & 0 & 0 & 0 & 1 & 0 & 1 & 0 & 0 & 0 & 0 & 0 & 0 & 0 & 0 & 0 & 0 & 2 & 8 \\
\hline 38 & 0 & 0 & 0 & 0 & 0 & 0 & 0 & 0 & 0 & 0 & 0 & 0 & 0 & 0 & 0 & 0 & 0 & 13 \\
\hline 39 & 0 & 0 & 0 & 0 & 0 & 0 & 0 & 0 & 0 & 0 & 0 & 0 & 0 & 0 & 0 & 0 & 0 & 13 \\
\hline 40 & 0 & 0 & 0 & 0 & 0 & 0 & 0 & 0 & 0 & 0 & 0 & 0 & 0 & 0 & 0 & 0 & 0 & 13 \\
\hline 41 & 0 & 0 & 0 & 0 & 0 & 0 & 0 & 0 & 0 & 0 & 0 & 0 & 0 & 0 & 0 & 0 & 0 & 13 \\
\hline 42 & 0 & 0 & 0 & 0 & 0 & 0 & 0 & 0 & 0 & 0 & 0 & 0 & 0 & 0 & 0 & 0 & 0 & 13 \\
\hline 43 & 2 & 2 & 2 & 2 & 2 & 2 & 2 & 0 & 0 & 2 & 2 & 2 & 0 & 2 & 0 & 0 & 22 & 4 \\
\hline 44 & 0 & 0 & 0 & 0 & 0 & 0 & 0 & 0 & 0 & 0 & 0 & 0 & 0 & 0 & 0 & 0 & 0 & 13 \\
\hline 45 & 0 & 0 & 0 & 0 & 0 & 0 & 0 & 0 & 0 & 0 & 0 & 0 & 0 & 0 & 0 & 0 & 0 & 13 \\
\hline
\end{tabular}


Table 10. Number of significant differences indicated by the Kruskal-Wallace and Kuiper statistical tests for comparisons between sample discharge and daily mean discharge data distribution for each constituent at 47 Ambient Water-Quality Monitoring Network sites with continuous discharge data.—Continued

[Cl, dissolved chloride; FC, fecal coliform; DO, dissolved oxygen; EC, Escherichia coli; NO3, nitrate plus nitrite; DP, dissolved phosphorus; TP, total phosphorus; DPb, dissolved lead; TPb, total recoverable lead; Q, sample discharge; SC, specific conductance; TSS, total suspended solids; WT, temperature; DZn, dissolved zinc; TZn, total recoverable zinc; --, no data]

\begin{tabular}{|c|c|c|c|c|c|c|c|c|c|c|c|c|c|c|c|c|c|c|}
\hline $\begin{array}{c}\text { Site (fig. 1, } \\
\text { table 1) }\end{array}$ & $\mathrm{Cl}$ & FC & DO & EC & NO3 & DP & TP & $\mathrm{DPb}$ & $\mathrm{TPb}$ & $\mathrm{pH}$ & 0 & SC & TSS & WT & DZn & TZn & $\begin{array}{c}\text { Total } \\
\text { significant } \\
\text { differences }\end{array}$ & $\begin{array}{l}\text { Rank of total } \\
\text { significant } \\
\text { differences }\end{array}$ \\
\hline 48 & 1 & 0 & 0 & 0 & 0 & 0 & 0 & 0 & 0 & 0 & 0 & 0 & 0 & 0 & 0 & 0 & 1 & 11 \\
\hline 49 & 1 & 0 & 0 & 0 & 0 & 0 & 0 & 0 & 0 & 0 & 0 & 0 & 0 & 0 & 0 & 0 & 1 & 11 \\
\hline 50 & 0 & 1 & 0 & 0 & 0 & 0 & 0 & 0 & 0 & 0 & 0 & 0 & 1 & 0 & 0 & 0 & 2 & 8 \\
\hline 51 & 0 & 0 & 0 & 0 & 0 & 0 & 0 & 0 & 0 & 0 & 0 & 0 & 0 & 0 & 0 & 0 & 0 & 13 \\
\hline 52 & 0 & 0 & 0 & 0 & 0 & 0 & 0 & 0 & 0 & 0 & 0 & 0 & 0 & 0 & 0 & 0 & 0 & 13 \\
\hline 53 & 0 & 0 & 0 & 0 & 0 & 0 & 0 & 0 & 0 & 0 & 0 & 0 & 0 & 0 & 0 & 0 & 0 & 13 \\
\hline 56 & 0 & 0 & 0 & 0 & 0 & 0 & 0 & 0 & 0 & 0 & 0 & 0 & 0 & 0 & 0 & 0 & 0 & 13 \\
\hline 58 & 0 & 0 & 0 & 0 & 0 & 0 & 0 & 0 & 0 & 0 & 0 & 0 & 0 & 0 & 0 & 0 & 0 & 13 \\
\hline 60 & 0 & 0 & 0 & 0 & 0 & 0 & 0 & 0 & 0 & 0 & 0 & 0 & 0 & 0 & 0 & 0 & 0 & 13 \\
\hline 61 & 0 & 0 & 0 & 0 & 0 & 0 & 0 & 0 & 0 & 0 & 0 & 0 & 0 & 0 & 0 & 0 & 0 & 13 \\
\hline 62 & 0 & 0 & 0 & 0 & 0 & 0 & 0 & 0 & 0 & 0 & 0 & 0 & 0 & 0 & 0 & 0 & 0 & 13 \\
\hline 63 & 0 & 0 & 0 & 0 & 0 & 0 & 0 & 0 & 0 & 0 & 0 & 0 & 0 & 0 & 0 & 0 & 0 & 13 \\
\hline 64 & 0 & 0 & 0 & 0 & 0 & 0 & 0 & 0 & 0 & 0 & 0 & 0 & 0 & 0 & 0 & 0 & 0 & 13 \\
\hline 65 & 0 & 0 & 0 & 0 & 0 & 0 & 0 & 0 & 0 & 0 & 0 & 0 & 0 & 0 & 0 & 0 & 0 & 13 \\
\hline 68 & 0 & 0 & 0 & 0 & 0 & 0 & 0 & 0 & 0 & 0 & 0 & 0 & 0 & 0 & 0 & 0 & 0 & 13 \\
\hline 69 & 0 & 0 & 0 & 0 & 0 & 1 & 0 & 1 & 1 & 1 & 0 & 0 & 1 & 0 & 1 & 1 & 7 & 6 \\
\hline 70 & 0 & 0 & 0 & 0 & 0 & 0 & 0 & 0 & 0 & 0 & 0 & 0 & 0 & 0 & 0 & 0 & 0 & 13 \\
\hline 71 & 0 & 0 & 0 & 0 & 0 & 0 & 0 & 0 & 0 & 0 & 0 & 0 & 0 & 0 & 0 & 0 & 0 & 13 \\
\hline
\end{tabular}


Table 11. Sum of the number of significant differences indicated by the Kruskal-Wallace and Kuiper statistical tests for comparisons between sample discharge and daily mean discharge data distribution for each constituent at 47 Ambient Water-Quality Monitoring Network sites with continuous discharge data.

$[--$, no data $]$

\begin{tabular}{lcc}
\hline \multicolumn{1}{c}{ Constituent } & $\begin{array}{c}\text { Number of } \\
\text { significant } \\
\text { differences }\end{array}$ & $\begin{array}{c}\text { Rank of the number of } \\
\text { significant differences }\end{array}$ \\
\hline Dissolved chloride & 10 & 4 \\
Fecal coliform & 10 & 4 \\
Dissolved oxygen & 9 & 7 \\
Escherichia coli & 8 & 11 \\
Nitrate plus nitrite & 9 & 7 \\
Dissolved phosphorus & 12 & 1 \\
Total phosphorus & 9 & 7 \\
Dissolved lead & 6 & 12 \\
Total recoverable lead & 4 & 14 \\
pH & 10 & 4 \\
Discharge & 11 & 2 \\
Specific conductance & 9 & 7 \\
Total suspended solids & 4 & 14 \\
Water temperature & 11 & 2 \\
Dissolved zinc & 6 & 12 \\
Total recoverable zinc & 4 & 14 \\
\hline
\end{tabular}

23 , the proportion of the daily mean discharge record where the daily mean discharge was less than the minimum sampled discharge ranged from 0 percent (sites 6, 24, and 56) to 3.90 percent (site 65). The higher percentages (greater than 1) tended to occur more frequently for sites with shorter periods (less than 5,000 days) of daily mean discharge record.

The results from tables 10, 11, and 12 generally indicate that sites that have been sampled during longer periods of record, are more frequently sampled during that period, are not Big River sites or sites that are affected by regulated discharge, and are sites that do not frequently go dry or are springs will tend to better represent the range of discharge during the period of analysis. To ensure samples represent the range of natural discharge conditions adequately, samples would need to be more frequently collected, collected during a longer period of time, or sampling rules would need to be modified to target specific discharge conditions from sites likely to have large discharge variability or short-lived large-magnitude changes in discharge.

\section{Sampling Frequency Analysis}

For general water-quality monitoring, which in many cases the AWQMN sites are designed to observe, samples are typically collected monthly, bimonthly, seasonally (or quarterly), semi-annually, annually, or on some other temporally predictable schedule. Given adequate sampling frequency and a sufficiently long sampling period, the distribution of values in the collection of samples tends to approach the distribution of the range of natural variation. It is impossible to know the true range of natural variation; however, samples that were collected on an approximately monthly schedule are assumed to be representative of the true range of natural variation in constituent concentrations for the following analysis. The sampling frequency analysis is designed to investigate if different sampling frequencies could approximate the range of natural variation of constituent concentrations at selected sites in the AWQMN and to determine what sites and constituents would be more sensitive to changes in sampling frequency.

To determine if different sampling frequencies at AWQMN sites that had a mean of 10 or more samples per year (28 sites; table 1) would produce the same data distribution as the original dataset, the constituent data at each site were resampled to simulate sampling frequencies shown in table 4. At each site, the simulated dataset for each of 11 constituents or measurements (DO, SC, pH, WT, TSS, NO3, DP, TP, EC, $\mathrm{FC}$, and discharge) was compared to the original constituent dataset to determine if a statistically significant difference was indicated in the two dataset distributions. These simulated sampling frequencies fell into five categories: 2 samples per season ( 8 samples per year), 1 sample per season (4 samples per year), 6 samples per year, 2 samples per year, and 1 sample per year.

A list of $p$-values of significance for the two-sample KW, KS2, and Kuiper tests was generated for each site, constituent, and simulated frequency group combination. The lists were aggregated by simulated frequency group in two ways, F_UNION and F_INTERSECTION, as described in the "Methods" section. Each aggregated matrix for each simulated frequency group had between 298 and 307 elements and varied because some constituents were not sampled at every site (table 4). For the F_UNION aggregate, a total of 2,039 significant differences were indicated from a possible 7,967 aggregated tests, or about 26 percent of the tests were significantly different (table 4). For the F_INTERSECTION aggregate, a total of 895 significant differences were indicated from a possible 7,967 aggregated tests, or about 11 percent of the tests were significantly different (table 4).

The F_UNION aggregate showed at least 1 significant difference for the following simulated sampling frequencies from table 4: q1SS01, q1SS03, q2SS01, all of the 2 samples 
Table 12. Maximum and minimum sampled discharge at the Ambient Water-Quality Monitoring Network sites and the percentage of the daily mean discharge record that was greater than the maximum sampled discharge or was less than the minimum sampled discharge.

\begin{tabular}{|c|c|c|c|c|c|c|c|c|}
\hline Site & Site name & $\begin{array}{l}\text { Maximum } \\
\text { sampled } \\
\text { daily } \\
\text { discharge, } \\
\text { cubic feet } \\
\text { per second }\end{array}$ & $\begin{array}{l}\text { Number of } \\
\text { days daily } \\
\text { discharge } \\
\text { greater than } \\
\text { maximum }\end{array}$ & $\begin{array}{l}\text { Minimum } \\
\text { sampled daily } \\
\text { discharge, } \\
\text { cubic feet per } \\
\text { second }\end{array}$ & $\begin{array}{l}\text { Number of days } \\
\text { daily discharge } \\
\text { less than minimum }\end{array}$ & $\begin{array}{l}\text { Number of days of } \\
\text { daily discharge record } \\
\text { for period of analysis }\end{array}$ & $\begin{array}{l}\text { Percentage of daily } \\
\text { discharge record with } \\
\text { values greater than } \\
\text { maximum sampled } \\
\text { discharge }\end{array}$ & $\begin{array}{l}\text { Percentage of daily } \\
\text { discharge record with } \\
\text { values less than minimum } \\
\text { sampled discharge }\end{array}$ \\
\hline 1 & $\begin{array}{l}\text { Fox River at Wayland, } \\
\text { Missouri }\end{array}$ & 6,040 & 85 & 0.16 & 18 & 9,131 & 0.93 & 0.20 \\
\hline 2 & $\begin{array}{l}\text { Wyaconda River above } \\
\text { Canton, Missouri }\end{array}$ & 2,280 & 408 & 0.23 & 23 & 9,131 & 4.47 & 0.25 \\
\hline 4 & $\begin{array}{l}\text { South Fabius River } \\
\text { near Taylor, } \\
\text { Missouri }\end{array}$ & 13,900 & 8 & 0.61 & 24 & 9,131 & 0.09 & 0.26 \\
\hline 5 & $\begin{array}{c}\text { Cuivre River near } \\
\text { Troy, Missouri }\end{array}$ & 26,900 & 21 & 1.29 & 45 & 9,131 & 0.23 & 0.49 \\
\hline 8 & $\begin{array}{l}\text { Missouri River at St. } \\
\text { Joseph, Missouri }\end{array}$ & 263,000 & 6 & 18,500 & 50 & 9,131 & 0.07 & 0.55 \\
\hline 9 & $\begin{array}{l}\text { Platte River at Sharps } \\
\text { Station, Missouri }\end{array}$ & 18,700 & 51 & 22.0 & 28 & 9,131 & 0.56 & 0.31 \\
\hline 18 & $\begin{array}{l}\text { Grand River near } \\
\text { Sumner, Missouri }\end{array}$ & 124,000 & 10 & 65.3 & 15 & 9,131 & 0.11 & 0.16 \\
\hline 19 & $\begin{array}{l}\text { Chariton River } \\
\text { near Prairie Hill, } \\
\text { Missouri }\end{array}$ & 30,600 & 22 & 33.6 & 43 & 9,131 & 0.24 & 0.47 \\
\hline 21 & $\begin{array}{l}\text { East Fork Little } \\
\text { Chariton River near } \\
\text { Huntsville, Missouri }\end{array}$ & 3,040 & 38 & 6.52 & 27 & 6,942 & 0.55 & 0.39 \\
\hline
\end{tabular}

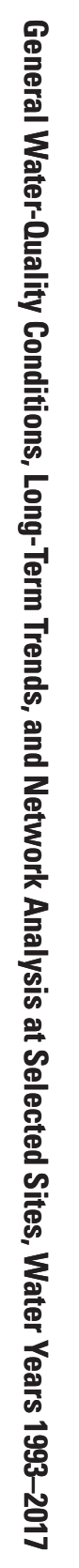


Table 12. Maximum and minimum sampled discharge at the Ambient Water-Quality Monitoring Network sites and the percentage of the daily mean discharge record that was greater than the maximum sampled discharge or was less than the minimum sampled discharge.-Continued

\begin{tabular}{|c|c|c|c|c|c|c|c|c|}
\hline Site & Site name & $\begin{array}{l}\text { Maximum } \\
\text { sampled } \\
\text { daily } \\
\text { discharge, } \\
\text { cubic feet } \\
\text { per second }\end{array}$ & $\begin{array}{l}\text { Number of } \\
\text { days daily } \\
\text { discharge } \\
\text { greater than } \\
\text { maximum }\end{array}$ & $\begin{array}{l}\text { Minimum } \\
\text { sampled daily } \\
\text { discharge, } \\
\text { cubic feet per } \\
\text { second }\end{array}$ & $\begin{array}{l}\text { Number of days } \\
\text { daily discharge } \\
\text { less than minimum }\end{array}$ & $\begin{array}{l}\text { Number of days of } \\
\text { daily discharge record } \\
\text { for period of analysis }\end{array}$ & $\begin{array}{l}\text { Percentage of daily } \\
\text { discharge record with } \\
\text { values greater than } \\
\text { maximum sampled } \\
\text { discharge }\end{array}$ & $\begin{array}{l}\text { Percentage of daily } \\
\text { discharge record with } \\
\text { values less than minimum } \\
\text { sampled discharge }\end{array}$ \\
\hline 24 & $\begin{array}{l}\text { Osage River above } \\
\text { Schell City, Missouri }\end{array}$ & 48,205 & 36 & 5.15 & 0 & 7,072 & 0.51 & 0.00 \\
\hline 26 & $\begin{array}{l}\text { Pomme de Terre River } \\
\text { near Polk, Missouri }\end{array}$ & 3,220 & 101 & 0.22 & 6 & 9,131 & 1.11 & 0.07 \\
\hline 27 & $\begin{array}{l}\text { South Grand River at } \\
\text { Archie, Missouri }\end{array}$ & 2,630 & 88 & 1.03 & 59 & 3,775 & 2.33 & 1.56 \\
\hline 29 & $\begin{array}{l}\text { Osage River below St. } \\
\text { Thomas, Missouri }\end{array}$ & 54,300 & 40 & 488 & 24 & 7,414 & 0.54 & 0.32 \\
\hline 33 & $\begin{array}{l}\text { Gasconade River } \\
\text { above Jerome, } \\
\text { Missouri }\end{array}$ & 30,733 & 59 & 286 & 33 & 9,129 & 0.65 & 0.36 \\
\hline 34 & $\begin{array}{l}\text { Missouri River at } \\
\text { Hermann, Missouri }\end{array}$ & 716,000 & 1 & 23,900 & 20 & 9,131 & 0.01 & 0.22 \\
\hline 35 & $\begin{array}{l}\text { Huzzah Creek near } \\
\text { Steelville, Missouri }\end{array}$ & 2,650 & 43 & 41.6 & 103 & 3,863 & 1.11 & 2.67 \\
\hline 37 & $\begin{array}{l}\text { Meramec River near } \\
\text { Sullivan, Missouri }\end{array}$ & 41,600 & 8 & 174 & 23 & 9,131 & 0.09 & 0.25 \\
\hline 38 & $\begin{array}{l}\text { Bourbeuse River above } \\
\text { Union, Missouri }\end{array}$ & 17,200 & 38 & 14.9 & 3 & 9,131 & 0.42 & 0.03 \\
\hline 39 & $\begin{array}{l}\text { Big River near } \\
\text { Richwoods, } \\
\text { Missouri }\end{array}$ & 10,500 & 73 & 45.0 & 10 & 8,766 & 0.83 & 0.11 \\
\hline 40 & $\begin{array}{l}\text { Meramec River at } \\
\text { Paulina Hills, } \\
\text { Missouri }\end{array}$ & 157,300 & 3 & 316 & 3 & 9,131 & 0.03 & 0.03 \\
\hline 41 & $\begin{array}{l}\text { South Fork Saline } \\
\text { Creek near } \\
\text { Perryville, Missouri }\end{array}$ & 396 & 140 & 4.92 & 133 & 6,138 & 2.28 & 2.17 \\
\hline 42 & $\begin{array}{l}\text { Castor River at } \\
\text { Greenbriar, Missouri }\end{array}$ & 15,200 & 15 & 42.7 & 9 & 6,171 & 0.24 & 0.15 \\
\hline
\end{tabular}


Table 12. Maximum and minimum sampled discharge at the Ambient Water-Quality Monitoring Network sites and the percentage of the daily mean discharge record that was greater than the maximum sampled discharge or was less than the minimum sampled discharge.-Continued

\begin{tabular}{|c|c|c|c|c|c|c|c|c|}
\hline Site & Site name & $\begin{array}{l}\text { Maximum } \\
\text { sampled } \\
\text { daily } \\
\text { discharge, } \\
\text { cubic feet } \\
\text { per second }\end{array}$ & $\begin{array}{l}\text { Number of } \\
\text { days daily } \\
\text { discharge } \\
\text { greater than } \\
\text { maximum }\end{array}$ & $\begin{array}{l}\text { Minimum } \\
\text { sampled daily } \\
\text { discharge, } \\
\text { cubic feet per } \\
\text { second }\end{array}$ & $\begin{array}{l}\text { Number of days } \\
\text { daily discharge } \\
\text { less than minimum }\end{array}$ & $\begin{array}{l}\text { Number of days of } \\
\text { daily discharge record } \\
\text { for period of analysis }\end{array}$ & $\begin{array}{l}\text { Percentage of daily } \\
\text { discharge record with } \\
\text { values greater than } \\
\text { maximum sampled } \\
\text { discharge }\end{array}$ & $\begin{array}{l}\text { Percentage of daily } \\
\text { discharge record with } \\
\text { values less than minimum } \\
\text { sampled discharge }\end{array}$ \\
\hline 43 & $\begin{array}{l}\text { Mississippi River } \\
\text { below Thebes, } \\
\text { Illinois }\end{array}$ & 966,000 & 4 & 74,300 & 98 & 9,131 & 0.04 & 1.07 \\
\hline 45 & $\begin{array}{l}\text { Big Creek at Sam A } \\
\text { Baker State Park, } \\
\text { Missouri }\end{array}$ & 1,210 & 150 & 8.83 & 42 & 4,383 & 3.42 & 0.96 \\
\hline 48 & $\begin{array}{l}\text { Roaring River Spring } \\
\text { at Cassville, } \\
\text { Missouri }\end{array}$ & 1,200 & 15 & 8.65 & 84 & 3,490 & 0.43 & 2.41 \\
\hline 49 & $\begin{array}{l}\text { Wilson Creek near } \\
\text { Brookline, Missouri }\end{array}$ & 498 & 67 & 10.4 & 16 & 5,927 & 1.13 & 0.27 \\
\hline 52 & $\begin{array}{l}\text { James River at Galena, } \\
\text { Missouri }\end{array}$ & 10,500 & 90 & 58.9 & 8 & 9,131 & 0.99 & 0.09 \\
\hline 53 & $\begin{array}{l}\text { Flat Creek below } \\
\text { Jenkins, Missouri }\end{array}$ & 6,210 & 15 & 15.1 & 19 & 3,803 & 0.39 & 0.50 \\
\hline 56 & $\begin{array}{l}\text { North Fork River near } \\
\text { Tecumseh, Missouri }\end{array}$ & 8,170 & 35 & 221 & 0 & 9,131 & 0.38 & 0.00 \\
\hline 58 & $\begin{array}{l}\text { Black River below } \\
\text { Annapolis, Missouri }\end{array}$ & 6,390 & 55 & 107 & 37 & 4,269 & 1.29 & 0.87 \\
\hline 60 & $\begin{array}{l}\text { Big Spring near Van } \\
\text { Buren, Missouri }\end{array}$ & 1,100 & 32 & 268 & 93 & 7,905 & 0.40 & 1.18 \\
\hline 61 & $\begin{array}{l}\text { Current River at } \\
\text { Doniphan, Missouri }\end{array}$ & 37,500 & 26 & 948 & 80 & 9,131 & 0.28 & 0.88 \\
\hline
\end{tabular}

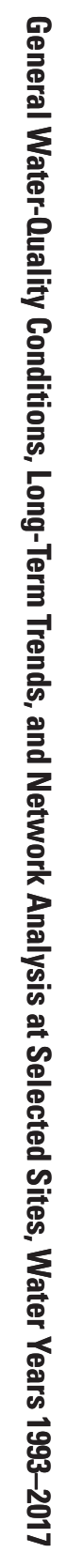


Table 12. Maximum and minimum sampled discharge at the Ambient Water-Quality Monitoring Network sites and the percentage of the daily mean discharge record that was greater than the maximum sampled discharge or was less than the minimum sampled discharge.-Continued

\begin{tabular}{|c|c|c|c|c|c|c|c|c|}
\hline Site & Site name & $\begin{array}{l}\text { Maximum } \\
\text { sampled } \\
\text { daily } \\
\text { discharge, } \\
\text { cubic feet } \\
\text { per second }\end{array}$ & $\begin{array}{l}\text { Number of } \\
\text { days daily } \\
\text { discharge } \\
\text { greater than } \\
\text { maximum }\end{array}$ & $\begin{array}{l}\text { Minimum } \\
\text { sampled daily } \\
\text { discharge, } \\
\text { cubic feet per } \\
\text { second }\end{array}$ & $\begin{array}{l}\text { Number of days } \\
\text { daily discharge } \\
\text { less than minimum }\end{array}$ & $\begin{array}{l}\text { Number of days of } \\
\text { daily discharge record } \\
\text { for period of analysis }\end{array}$ & $\begin{array}{l}\text { Percentage of daily } \\
\text { discharge record with } \\
\text { values greater than } \\
\text { maximum sampled } \\
\text { discharge }\end{array}$ & $\begin{array}{l}\text { Percentage of daily } \\
\text { discharge record with } \\
\text { values less than minimum } \\
\text { sampled discharge }\end{array}$ \\
\hline 63 & $\begin{array}{l}\text { Greer Spring at Greer, } \\
\text { Missouri }\end{array}$ & 733 & 54 & 112 & 27 & 9,131 & 0.59 & 0.30 \\
\hline 64 & $\begin{array}{l}\text { Eleven Point River } \\
\text { near Bardley, } \\
\text { Missouri }\end{array}$ & 6,070 & 46 & 202 & 80 & 9,131 & 0.50 & 0.88 \\
\hline 65 & $\begin{array}{l}\text { Spring River above } \\
\text { Carthage, Missouri }\end{array}$ & 4,750 & 38 & 37.5 & 233 & 5,980 & 0.64 & 3.90 \\
\hline 68 & $\begin{array}{r}\text { Shoal Creek above } \\
\text { Joplin, Missouri }\end{array}$ & 14,100 & 9 & 48.9 & 3 & 9,131 & 0.10 & 0.03 \\
\hline 69 & $\begin{array}{l}\text { Little Sugar Creek near } \\
\text { Pineville, Missouri }\end{array}$ & 9,700 & 7 & 12.6 & 20 & 4,748 & 0.15 & 0.42 \\
\hline 70 & $\begin{array}{l}\text { Elk River near Tiff } \\
\text { City, Missouri }\end{array}$ & 28,000 & 10 & 37.7 & 19 & 9,131 & 0.11 & 0.21 \\
\hline 71 & $\begin{array}{l}\text { Buffalo Creek at Tiff } \\
\text { City, Missouri }\end{array}$ & 6,740 & 2 & 0.15 & 44 & 6,339 & 0.03 & 0.69 \\
\hline
\end{tabular}


per year frequency groups, and all of the 1 sample per year frequency groups. The percentage of the total aggregated results for the simulated sampling frequencies that showed a significant difference ranged from less than 1 to about 56 percent, with the less frequently sampled simulated groups $(2$ per year and 1 per year) having the larger percentage of significant differences. Simulated sampling frequencies of 1 per season, 2 per season, and 6 per year had a maximum of about 2 percent significant differences.

The F_INTERSECTION aggregate showed at least 1 significant difference for all of the 2 samples per year frequency groups and all of the 1 sample per year frequency groups (table 4). The percentage of the total aggregated results for the simulated sampling frequencies that showed a significant difference ranged from about 1 to about 35 percent, with the less frequently sampled simulated group (1 per year) having the larger percentage of significant differences. Simulated sampling frequencies of 1 per season, 2 per season, and 6 per year had zero significant differences.

It could be interpreted from table 4 that, as a group, the 28 sites analyzed would have a minor statistical change in data distribution if the sampling was reduced to a frequency of 1 sample per season and that there would be no change in data distribution if the frequency of sampling were reduced to 6 times per year. If sampling was reduced for this group to 2 times per year, the least disruptive change in data distribution (based on the mean of the F_UNION and F_INTERSECTION aggregated results) would occur in simulated frequency group y2SS06, which would have been sampled in the months of March and September. If sampling was reduced for this group to 1 time per year, the least disruptive change in data distribution (based on the mean of the F_UNION and F_INTERSECTION aggregated results) would occur in simulated frequency group y1SS10, which would have been sampled in October.

The total number of significant differences in the $\mathrm{F}_{-}$ UNION and F_INTERSECTION aggregation groups were computed for each of the 28 AWQMN sites and 11 constituents used in the frequency analysis (tables 13 and 14). Each aggregated matrix for each AWQMN site had between 260 and 286 elements and varied because some constituents were not sampled at every site. The percentage of the total significant differences summed for all simulated frequency groups for each of the 28 AWQMN sites ranged from about 14 to about 40 percent for the F_UNION aggregated group and from about 6 to about 19 percent for the F_INTERSECTION aggregated group (table 13). Each aggregated matrix for each constituent had between 693 and 728 elements and varied because some constituents were not sampled at every site. The percentage of the total significant differences summed for all simulated frequency groups for each of the 11 constituents, ranged from about 7 to about 66 percent for the F_UNION aggregated group and from about 1 to about 36 percent for the F_INTERSECTION aggregated group (table 14).

Sites were ranked based on the percentage of significant differences for the F_UNION and F_INTERSECTION aggregate groups and a composite rank was determined based on the mean of the percentage of significant differences in the F_UNION and F_INTERSECTION aggregate groups. For the 28 sites, the rank is presumed to indicate the relative sensitivity of any given site to changes in sampling frequency among the group of sites (table 13). For example, a site with rank 5 is presumed to be more sensitive to changes in sampling frequency than any site with rank 6 or greater. It should be noted that the relative sensitivity to sampling frequency changes is almost entirely driven by the simulated sampling frequencies of 1 and 2 samples per year; simulated sampling frequencies of 4 or more samples per year have few significant differences. As a result, sites with shorter operational periods will have a smaller simulated sampling set compared to sites with longer operational periods. The smaller simulated sampling sets (particularly with the simulated sampling frequencies of 1 sample per year, which equates to about 9 yearly samples for the site with the shortest operational period in this group) may be approaching the limit of a statistically valid sample size, which could somewhat affect the analysis for some sites.

The top 4 sites most sensitive to sampling frequency changes are Big River sites on the Missouri and Mississippi Rivers, and 7 of the top 10 most sensitive are classified as either very large or large basins. Six of the 10 sites least sensitive to sampling frequency changes are within the Springfield Plateau section of the Ozark Plateaus Province, and all 6 are classified to be either small or medium basin size and are a mixture of agricultural and forested land use (fig. 3). Six of 7 sites within the DTPL generally ranked in the intermediate range for sensitivity to sampling frequency changes (ranks 10 through 18) and are from agriculturally dominated basins with a variety of basin sizes ranging from small to large. Sites most sensitive to sampling frequency changes tended to have longer sampling periods (operational period for the top 10 mean to about 8,500 days during the analysis period), whereas sites least sensitive to sampling frequency changes tended to have shorter sampling periods (operational period for the bottom 10 mean to about 5,300 days during the analysis period).

Constituents were ranked based on the percentage of significant differences for the F_UNION and F_INTERSECTION aggregate groups and a composite rank was determined based on the mean of the percentage of significant differences in the F_UNION and F_INTERSECTION aggregate groups. For the 11 constituents, the rank is presumed to indicate the relative sensitivity of any given constituent to changes in sampling frequency among the group of constituents (table 14). The five most sensitive constituents to sampling frequency changes were WT, DO, discharge, NO3, and SC. These five constituents were ranked in the top five in the F_UNION and F_INTERSECTION aggregate groups and in the composite rank of the two groups.

It should be noted that although changing the sampling frequency for this particular group of AWQMN sites and constituents might result in a statistically similar (or different) data distribution during a 25-year sampling period, the frequency selected may not provide sufficient data to monitor constituent concentrations in a particular season or period, 
Table 13. Aggregated number of significant differences, approximate percentage of significant differences, and site relative sensitivity to the simulated change in data collection frequency.

\begin{tabular}{|c|c|c|c|c|c|c|c|c|c|}
\hline \multirow[b]{2}{*}{$\begin{array}{l}\text { Site } \\
\text { (table 1, } \\
\text { fig. 1) }\end{array}$} & \multirow[b]{2}{*}{ Site name } & \multicolumn{3}{|c|}{ F_UNION aggregation ${ }^{1}$} & \multicolumn{3}{|c|}{ F_INTERSECTION aggregation² } & \multirow[b]{2}{*}{$\begin{array}{l}\text { Rank of the mean } \\
\text { of the F_UNION and } \\
\text { F_INTERSECTION } \\
\text { percentage of } \\
\text { significant } \\
\text { differences }\end{array}$} & \multirow[b]{2}{*}{$\begin{array}{c}\text { Total } \\
\text { number of } \\
\text { aggregated } \\
\text { statistical } \\
\text { tests }\end{array}$} \\
\hline & & $\begin{array}{l}\text { Number of significant } \\
\text { differences between } \\
\text { the original data } \\
\text { and the simulated } \\
\text { frequency datasets }\end{array}$ & $\begin{array}{c}\text { Approximate } \\
\text { percentage } \\
\text { of significant } \\
\text { differences }\end{array}$ & $\begin{array}{l}\text { Rank of the } \\
\text { approximate } \\
\text { percentage } \\
\text { of significant } \\
\text { differences }\end{array}$ & $\begin{array}{l}\text { Number of significant } \\
\text { differences between } \\
\text { the original data and } \\
\text { the simulated } \\
\text { frequency datasets }\end{array}$ & $\begin{array}{c}\text { Approximate } \\
\text { percentage } \\
\text { of significant } \\
\text { differences }\end{array}$ & $\begin{array}{l}\text { Rank of the } \\
\text { approximate } \\
\text { percentage } \\
\text { of significant } \\
\text { differences }\end{array}$ & & \\
\hline 4 & $\begin{array}{l}\text { South Fabius River } \\
\text { near Taylor, } \\
\text { Missouri }\end{array}$ & 73 & 26 & 11 & 33 & 12 & 10 & 11 & 286 \\
\hline 6 & $\begin{array}{l}\text { Mississippi River } \\
\text { below Grafton, } \\
\text { Illinois }\end{array}$ & 95 & 33 & 4 & 42 & 15 & 4 & 4 & 286 \\
\hline 8 & $\begin{array}{l}\text { Missouri River } \\
\text { at St. Joseph, } \\
\text { Missouri }\end{array}$ & 102 & 36 & 3 & 49 & 17 & 3 & 3 & 286 \\
\hline 10 & $\begin{array}{l}\text { Missouri River at } \\
\text { Sibley, Missouri }\end{array}$ & 52 & 18 & 27 & 21 & 7 & 24 & 27 & 286 \\
\hline 14 & $\begin{array}{l}\text { No Creek near } \\
\text { Dunlap, Missouri }\end{array}$ & 70 & 24 & 15 & 30 & 10 & 15 & 15 & 286 \\
\hline 15 & $\begin{array}{l}\text { Medicine Creek } \\
\text { near Harris, } \\
\text { Missouri }\end{array}$ & 72 & 25 & 12 & 30 & 10 & 15 & 14 & 286 \\
\hline 16 & $\begin{array}{l}\text { Little Medicine } \\
\text { Creek near } \\
\text { Harris, Missouri }\end{array}$ & 72 & 25 & 12 & 32 & 11 & 13 & 12 & 286 \\
\hline 17 & $\begin{array}{l}\text { Locust Creek near } \\
\text { Unionville, } \\
\text { Missouri }\end{array}$ & 75 & 26 & 10 & 36 & 13 & 9 & 10 & 286 \\
\hline 18 & $\begin{array}{l}\text { Grand River near } \\
\quad \text { Sumner, Missouri }\end{array}$ & 86 & 30 & 6 & 39 & 14 & 8 & 7 & 286 \\
\hline 20 & $\begin{array}{l}\text { Mussel fork near } \\
\text { Mystic, Missouri }\end{array}$ & 60 & 21 & 23 & 23 & 8 & 23 & 22 & 286 \\
\hline 25 & $\begin{array}{l}\text { Little Sac River } \\
\text { near Walnut } \\
\text { Grove, Missouri }\end{array}$ & 85 & 30 & 7 & 40 & 14 & 7 & 6 & 286 \\
\hline 33 & $\begin{array}{l}\text { Gasconade River } \\
\text { above Jerome, } \\
\text { Missouri }\end{array}$ & 64 & 22 & 19 & 30 & 10 & 15 & 19 & 286 \\
\hline
\end{tabular}


Table 13. Aggregated number of significant differences, approximate percentage of significant differences, and site relative sensitivity to the simulated change in data collection frequency.-Continued

\begin{tabular}{|c|c|c|c|c|c|c|c|c|c|}
\hline \multirow[b]{2}{*}{$\begin{array}{c}\text { Site } \\
\text { (table 1, } \\
\text { fig. 1) }\end{array}$} & \multirow[b]{2}{*}{ Site name } & \multicolumn{3}{|c|}{ F_UNION aggregation ${ }^{1}$} & \multicolumn{3}{|c|}{ F_INTERSECTION aggregation² } & \multirow[b]{2}{*}{$\begin{array}{l}\text { Rank of the mean } \\
\text { of the F_UNION and } \\
\text { F_INTERSECTION } \\
\text { percentage of } \\
\text { significant } \\
\text { differences }\end{array}$} & \multirow[b]{2}{*}{$\begin{array}{l}\text { Total } \\
\text { number of } \\
\text { aggregated } \\
\text { statistical } \\
\text { tests }\end{array}$} \\
\hline & & $\begin{array}{l}\text { Number of significant } \\
\text { differences between } \\
\text { the original data } \\
\text { and the simulated } \\
\text { frequency datasets }\end{array}$ & $\begin{array}{l}\text { Approximate } \\
\text { percentage } \\
\text { of significant } \\
\text { differences }\end{array}$ & $\begin{array}{l}\text { Rank of the } \\
\text { approximate } \\
\text { percentage } \\
\text { of significant } \\
\text { differences }\end{array}$ & $\begin{array}{l}\text { Number of significant } \\
\text { differences between } \\
\text { the original data } \\
\text { and the simulated } \\
\text { frequency datasets }\end{array}$ & $\begin{array}{l}\text { Approximate } \\
\text { percentage } \\
\text { of significant } \\
\text { differences }\end{array}$ & $\begin{array}{l}\text { Rank of the } \\
\text { approximate } \\
\text { percentage } \\
\text { of significant } \\
\text { differences }\end{array}$ & & \\
\hline 34 & $\begin{array}{l}\text { Missouri River } \\
\text { at Hermann, } \\
\text { Missouri }\end{array}$ & 99 & 38 & 2 & 47 & 18 & 2 & 2 & 260 \\
\hline 37 & $\begin{array}{l}\text { Meramec River } \\
\text { near Sullivan, } \\
\text { Missouri }\end{array}$ & 71 & 25 & 14 & 33 & 12 & 10 & 12 & 286 \\
\hline 40 & $\begin{array}{l}\text { Meramec River at } \\
\text { Paulina Hills, } \\
\text { Missouri }\end{array}$ & 90 & 31 & 5 & 41 & 14 & 5 & 5 & 286 \\
\hline 43 & $\begin{array}{l}\text { Mississippi River } \\
\text { below Thebes, } \\
\text { Illinois }\end{array}$ & 112 & 40 & 1 & 52 & 19 & 1 & 1 & 279 \\
\hline 47 & $\begin{array}{l}\text { Little River Ditches } \\
\text { near Rives, } \\
\text { Missouri }\end{array}$ & 81 & 28 & 8 & 33 & 12 & 10 & 9 & 286 \\
\hline 51 & $\begin{array}{l}\text { Finley Creek } \\
\text { below Riverdale, } \\
\text { Missouri }\end{array}$ & 58 & 20 & 26 & 25 & 9 & 22 & 22 & 286 \\
\hline 52 & $\begin{array}{l}\text { James River at } \\
\text { Galena, Missouri }\end{array}$ & 64 & 22 & 19 & 26 & 9 & 21 & 20 & 286 \\
\hline 53 & $\begin{array}{l}\text { Flat Creek below } \\
\text { Jenkins, Missouri }\end{array}$ & 41 & 14 & 28 & 18 & 6 & 28 & 28 & 286 \\
\hline 61 & $\begin{array}{l}\text { Current River } \\
\text { at Doniphan, } \\
\text { Missouri }\end{array}$ & 66 & 23 & 18 & 31 & 11 & 14 & 17 & 286 \\
\hline 65 & $\begin{array}{l}\text { Spring River } \\
\text { above Carthage, } \\
\text { Missouri }\end{array}$ & 59 & 21 & 24 & 20 & 7 & 26 & 25 & 286 \\
\hline 66 & $\begin{array}{l}\text { Center Creek near } \\
\text { Smithfield, } \\
\text { Missouri }\end{array}$ & 77 & 27 & 9 & 40 & 14 & 6 & 8 & 285 \\
\hline 67 & $\begin{array}{l}\text { Turkey Creek near } \\
\text { Joplin, Missouri }\end{array}$ & 66 & 24 & 16 & 27 & 10 & 19 & 18 & 279 \\
\hline
\end{tabular}


Table 13. Aggregated number of significant differences, approximate percentage of significant differences, and site relative sensitivity to the simulated change in data collection frequency.-Continued

\begin{tabular}{|c|c|c|c|c|c|c|c|c|c|}
\hline \multirow[b]{2}{*}{$\begin{array}{c}\text { Site } \\
\text { (table 1, } \\
\text { fig. 1) }\end{array}$} & \multirow[b]{2}{*}{ Site name } & \multicolumn{3}{|c|}{ F_UNION aggregation ${ }^{1}$} & \multicolumn{3}{|c|}{ F_INTERSECTION aggregation² } & \multirow[b]{2}{*}{$\begin{array}{l}\text { Rank of the mean } \\
\text { of the F_UNION and } \\
\text { F_INTERSECTION } \\
\text { percentage of } \\
\text { significant } \\
\text { differences }\end{array}$} & \multirow[b]{2}{*}{$\begin{array}{c}\text { Total } \\
\text { number of } \\
\text { aggregated } \\
\text { statistical } \\
\text { tests }\end{array}$} \\
\hline & & $\begin{array}{l}\text { Number of significant } \\
\text { differences between } \\
\text { the original data } \\
\text { and the simulated } \\
\text { frequency datasets }\end{array}$ & $\begin{array}{l}\text { Approximate } \\
\text { percentage } \\
\text { of significant } \\
\text { differences }\end{array}$ & $\begin{array}{l}\text { Rank of the } \\
\text { approximate } \\
\text { percentage } \\
\text { of significant } \\
\text { differences }\end{array}$ & $\begin{array}{l}\text { Number of significant } \\
\text { differences between } \\
\text { the original data } \\
\text { and the simulated } \\
\text { frequency datasets }\end{array}$ & $\begin{array}{c}\text { Approximate } \\
\text { percentage } \\
\text { of significant } \\
\text { differences }\end{array}$ & $\begin{array}{l}\text { Rank of the } \\
\text { approximate } \\
\text { percentage } \\
\text { of significant } \\
\text { differences }\end{array}$ & & \\
\hline 68 & $\begin{array}{l}\text { Shoal Creek above } \\
\text { Joplin, Missouri }\end{array}$ & 61 & 21 & 22 & 21 & 7 & 24 & 24 & 286 \\
\hline 69 & $\begin{array}{l}\text { Little Sugar Creek } \\
\text { near Pineville, } \\
\text { Missouri }\end{array}$ & 62 & 22 & 21 & 27 & 9 & 20 & 21 & 286 \\
\hline 70 & $\begin{array}{c}\text { Elk River near Tiff } \\
\text { City, Missouri }\end{array}$ & 67 & 23 & 17 & 30 & 10 & 15 & 16 & 286 \\
\hline 71 & $\begin{array}{c}\text { Buffalo Creek } \\
\text { at Tiff City, } \\
\text { Missouri }\end{array}$ & 59 & 21 & 24 & 19 & 7 & 27 & 26 & 286 \\
\hline
\end{tabular}

${ }^{1}$ F_UNION refers to the aggregation method where for each site/constituent/simulated frequency combination, individual statistical tests were aggregated to an F_UNION significant difference if any of the individual statistical tests indicated a significant difference. For additional details, see the "Sampling frequency analysis" section in the methods section of the report.

${ }^{2} \mathrm{~F}$ INTERSECTION refers to the aggregation method where for each site/constituent/simulated frequency combination, individual statistical tests were aggregated to a F INTERSECTION significant difference if all the individual statistical tests indicated a significant difference. For additional details, see the "Sampling frequency analysis" section in the methods section of the report. 
Table 14. Aggregated number of significant differences, approximate percentage of significant differences, and constituent relative sensitivity to the simulated change in data collection frequency.

\begin{tabular}{|c|c|c|c|c|c|c|c|c|}
\hline \multirow[b]{2}{*}{ Constituent } & \multicolumn{3}{|c|}{ F_UNION aggregation ${ }^{1}$} & \multicolumn{3}{|c|}{ F_INTERSECTION aggregation² } & \multirow[b]{2}{*}{$\begin{array}{l}\text { Rank of the mean } \\
\text { of the F_UNION and } \\
\text { F_INTERSECTION } \\
\text { percentage of } \\
\text { significant differences }\end{array}$} & \multirow[b]{2}{*}{$\begin{array}{c}\text { Total number } \\
\text { of aggregated } \\
\text { statistical } \\
\text { tests }\end{array}$} \\
\hline & $\begin{array}{l}\text { Number of significant } \\
\text { differences between } \\
\text { the original data } \\
\text { and the simulated } \\
\text { frequency datasets }\end{array}$ & $\begin{array}{l}\text { Approximate } \\
\text { percentage } \\
\text { of significant } \\
\text { differences }\end{array}$ & $\begin{array}{l}\text { Rank of the } \\
\text { approximate } \\
\text { percentage } \\
\text { of significant } \\
\text { differences }\end{array}$ & $\begin{array}{l}\text { Number of significant } \\
\text { differences between } \\
\text { the original data } \\
\text { and the simulated } \\
\text { frequency datasets }\end{array}$ & $\begin{array}{l}\text { Approximate } \\
\text { percentage } \\
\text { of significant } \\
\text { differences }\end{array}$ & $\begin{array}{l}\text { Rank of the } \\
\text { approximate } \\
\text { percentage } \\
\text { of significant } \\
\text { differences }\end{array}$ & & \\
\hline Dissolved oxygen & 362 & 50 & 2 & 221 & 30 & 2 & 2 & 727 \\
\hline Specific conductance & 164 & 23 & 5 & 76 & 10 & 5 & 5 & 728 \\
\hline $\mathrm{pH}$ & 51 & 7 & 11 & 7 & 1 & 11 & 11 & 728 \\
\hline Water temperature & 480 & 66 & 1 & 259 & 36 & 1 & 1 & 728 \\
\hline Total suspended solids & 87 & 13 & 10 & 28 & 4 & 10 & 10 & 693 \\
\hline Nitrate plus nitrite & 196 & 27 & 3 & 76 & 10 & 4 & 4 & 727 \\
\hline Dissolved phosphorus & 106 & 15 & 9 & 36 & 5 & 6 & 9 & 727 \\
\hline Total phosphorus & 117 & 16 & 8 & 36 & 5 & 6 & 8 & 727 \\
\hline Escherichia coli & 137 & 19 & 7 & 35 & 5 & 8 & 7 & 727 \\
\hline Fecal coliform & 145 & 20 & 6 & 33 & 5 & 9 & 6 & 727 \\
\hline Discharge & 194 & 27 & 4 & 88 & 12 & 3 & 3 & 728 \\
\hline
\end{tabular}

${ }^{1}{ }^{F} \_$UNION refers to the aggregation method where for each site/constituent/simulated frequency combination, individual statistical tests were aggregated to an $\mathrm{F}_{-} \mathrm{UNION}$ significant difference if any of the individual statistical tests indicated a significant difference. For additional details, see the "Sampling frequency analysis" section in the methods section of the report.

${ }^{2}$ F_INTERSECTION refers to the aggregation method where for each site/constituent/simulated frequency combination, individual statistical tests were aggregated to a F_INTERSECTION significant difference if all the individual statistical tests indicated a significant difference. For additional details, see the "Sampling frequency analysis" section in the methods section of the report. 
analyze trends, explore constituent flux and transport, or perform other analyses on the data. Sampling design, including the sites, constituent list, and frequency, would benefit from consideration of the intended end use, or potential future uses, of the data to maximize the utility of the monitoring network. The potential effect of a reduced sampling frequency on trends is addressed in the "Trends from Simulated Reduced Frequency Dataset" section.

\section{Trends from Simulated Reduced Frequency Dataset}

Various simulated sampling frequencies were evaluated to determine what minimum sampling frequency would be needed to approximate the natural variation of constituent concentrations. Long-term trends in selected water-quality constituents were evaluated based on all of the samples collected at the selected AWQMN sites. Long-term trends, using the minimum simulated sampling frequency that approximated the natural variation, were evaluated to determine how well the reduced sampling frequency dataset reproduced the long-term trends identified using the full dataset at select AWQMN sites.

To explore if trend analysis using a reduced frequency dataset would obtain similar long-term trends that were observed using monthly data, a total of 22 sites (table 1) were reevaluated using a simulated quarterly sampling frequency dataset. Results from the sampling frequency analysis indicated that quarterly sampling could produce a similar data distribution to monthly sampled data. A quarterly simulated frequency group, with about 2 percent significant differences from the monthly data, was chosen to evaluate a 'worst case' quarterly sampling frequency condition. The dataset was produced by selecting the constituent data for each of the months of March, June, September, and December at 22 sites during their respective sampling periods. This simulated quarterly sampling frequency dataset was evaluated for trends using the identical discharge-adjusted routine using the R-QWTREND software as done previously with the complete dataset. Data for $\mathrm{DPb}, \mathrm{DZn}, \mathrm{TPb}$, and TZn at all 22 sites were not collected with sufficient frequency to be analyzed in the reduced dataset, and these constituents are not included in the following discussion of the 22 reevaluated sites. A total of 242 trend analyses were evaluated for the 22 sites and 11 constituents (WT, DO, SC, pH, NO3, TP, DP, Cl, EC, FC, and TSS). The trend analysis of these 22 sites using the monthly analytical results (not including $\mathrm{DPb}, \mathrm{DZn}, \mathrm{TPb}$, and TZn) obtained 195 best-fit models that indicated 102 with no trend (null), 80 with a single-period trend, and 13 with a two-period trend (table 6). There was a total of 47 trend analyses for these sites that could not be completed because minimum data requirements for the trends software were not met or were not completed because of other data limitations (table 6).

Analysis of the 22 sites using the reduced frequency dataset obtained a total of 150 best-fit models that indicated 105 with no trend, 43 with a single-period trend, and 2 with a two-period trend (table 15). There was a total of 92 trend analyses for these sites that were not completed because minimum data requirements for the trends software were not met or were not completed because of other data limitations (table 15). An example of the spatial distribution, concentration range, significance, direction, and percent change for WT trends from the reduced frequency dataset is shown in figure 26, and similar plots for the 11 constituents analyzed using the reduced frequency dataset can be obtained from a USGS data release (Richards and Barr, 2021).

There were 102 analyses indicating no trend in the monthly data, of which 66 were identified as indicating no trend and 3 indicated nonsignificant single-period trends (which fundamentally is equivalent to no trend) using the reduced dataset. Of the remaining 33 analyses, 30 could not be completed because of software data limitations and 3 indicated a significant single-period trend. The overall success rate of reproducing similar no-trend results with the reduced dataset was about 65 percent.

There were 80 single-period trends identified using the monthly data, and analyses of the reduced dataset identified 37 matching single-period trends (table 16). Of the 43 nonmatching single-period trends in the reduced dataset, 18 analyses could not be completed because of data limitations and 25 indicated no trend. Of the 69 significant single-period trends in the monthly data, 32 matching significant single-period trends having the same direction were identified in the reduced dataset. The overall success rate of reproducing similar significant single-period trends with a reduced dataset was about 46 percent.

There were 13 two-period trends identified in the monthly data, and only 1 had a matching two-period trend identified in the reduced dataset (table 16). The matching two-period trend using the monthly data was significant for both periods, whereas the two-period trend using the reduced dataset was significant only for one period (tables 6 and 15). For the other 12 nonmatching two-period trends identified using the monthly data, 1 was identified as a single-period trend and 11 were identified as no trend using the reduced dataset. The overall success rate of reproducing similar two-period significant trends with a reduced dataset was about 4 percent.

The success rate of reproducing a no-trend result from the reduced dataset for individual site and constituent when compared to the results obtained using the monthly dataset ranged between 17 and 100 percent with a mean of about 64 percent for all constituents analyzed in table 16 . The success rate of reproducing a significant single-period trend result from the reduced dataset when compared to the results obtained using the monthly dataset ranged between 17 and 100 percent with a mean of about 52 percent for all constituents analyzed in table 16. The top 5 constituents with the highest ( 69 percent or greater) success rate of reproducing a no-trend result using the reduced dataset were TSS, pH, WT, DO, and EC. The top 5 constituents with the highest (56 percent or greater) success rate of reproducing a significant single-period trend result using the reduced dataset were TSS, FC, DP, TP, and SC. 
For the individual sites, the success rate of reproducing a no-trend result for the constituents from the reduced dataset when compared to the results obtained using the monthly dataset ranged between 0 and 100 percent with a mean of about 65 percent for all sites analyzed in table 16 . The success rate of reproducing a significant single-period trend result from the reduced dataset when compared to the results obtained using the monthly dataset ranged between 0 and 100 percent with a mean of about 49 percent for all sites analyzed. Eight of the top 10 sites in table 16 with higher success rates of reproducing no trends from the reduced dataset were classified as having a large or very large basin size (table 1). Seven of the bottom 10 sites in table 16 with the lowest success rates of reproducing no trends from the reduced dataset were classified as having a small or medium basin size (table 1).

\section{Continuous Discharge Estimation at Ungaged AWOMN Sites}

A key component in long-term trends analysis is the availability of continuous discharge at the site. Continuous discharge at ungaged sites can be estimated based on nearby sites where continuous discharge is collected. If the estimated continuous discharge is of sufficient quality, then the more rigorous discharge-weighted long-term trends analysis could be performed. Continuous discharge was estimated at select ungaged sites in the AWQMN to explore the viability of using estimated discharge with R-QWTREND to compute trends at ungaged locations. Missouri has many long-term streamgages distributed throughout the State. To estimate daily mean discharge for the ungaged AWQMN sites, alternate discharge sites within the same basin or an adjacent basin were chosen (table 17).

Regression model $r^{2}$ values varied from 0.433 to 0.992 , indicating that all models were moderately correlated or better, which was expected. AWQMN sites that had the alternate discharge site on the same stream tended to have higher correlation coefficients (mean $r^{2}$ of 0.774 ) than those that were from adjacent basins (mean $r^{2}$ of 0.670). The two-sample KW and Kuiper tests indicated significant differences in the medians and distributions at sites $14,20,46,57$, and 66 , and sites 11 , 17,22 , and 25 showed significant differences in one of the tests. Sites with significant differences in the two-sample KW or Kuiper tests and $r^{2}$ values less than 0.7 were 14, 20, 22, and 46. A value of 1 for the scaling exponent in a power function would represent a linear correlation between the sampled discharge and the alternate site discharge, and the power function coefficient would represent a scaling factor in that case. However, for the 21 sites tested, the scaling exponents mostly were not close to 1 (absolute difference from 1 greater than about 0.005 ), so in most cases, the data are not likely to be linearly correlated. The cause of the statistically significant heteroscedasticity observed in the residuals of ungaged sites $20,22,55$, and 57 is unknown, but the regression models for those sites should be used with caution.
Two sites with continuous discharge data (sites 29 and 39 ; table 17) were missing daily mean discharge record for water year 2001, and the data gap was estimated so that the trend analysis could be completed. Estimating the discharge for these two sites was accomplished using the same methods as with the ungaged sites. Additional evaluation of the estimated discharge record compared with the measured record was done at these two sites to provide a frame of reference for the reliability of the estimates at the ungaged sites. For site 29 from water year 1993 through 2017, the minimum, median, mean, and maximum daily mean discharge for the measured record was about $320 ; 5,145 ; 12,154$; and 114,000 cubic feet per second $\left(\mathrm{ft}^{3} / \mathrm{s}\right)$, respectively, and for the estimated record was about $340 ; 4,490 ; 11,431$; and $104,976 \mathrm{ft}^{3} / \mathrm{s}$, respectively. The regression relation at site 29 tends to somewhat underestimate most discharges but to a lesser extent for values greater than the median discharge value. The estimated record represents about 94 percent of the total discharge volume of the measured record for site 29 for the analysis period. For site 39 from water year 1993 through 2017, the minimum, median, mean, and maximum daily mean discharge for the measured record was about $41 ; 316 ; 796$; and $53,600 \mathrm{ft}^{3} / \mathrm{s}$, respectively, and for the estimated record was about 50;312; 692 ; and $32,680 \mathrm{ft}^{3} / \mathrm{s}$, respectively. The regression relation at site 39 appears to represent the median and lower discharges well but somewhat underestimates the higher discharges. The estimated record represents about 87 percent of the total discharge volume of the measured record for site 39 . A comparison of the measured and estimated discharge for a short period around the missing data for site 39 is shown in figure 27. It is unknown how well the estimated discharge values match the true discharge at the ungaged sites; however, it might be assumed that ungaged sites with similar regression relations, drainage area ratio (DAR) values, and $r^{2}$ values to sites 29 and 39 might give similar results.

For sites that had a DAR less than or equal to 0.70 , about 46 percent ( 6 of 13 sites) had an $r^{2}$ value of less than 0.7 , whereas for sites with a DAR greater than 0.70 , about 80 percent ( 8 of 10 sites) had an $r^{2}$ value of greater than 0.7 . The two sites with a DAR greater than 1.63 had an $r^{2}$ value of less than 0.7. Sites 10, 15, 29, 32, 39, 55, and 59 (table 17) with regression models that are strongly correlated and have a DAR between 0.7 and 1.63 are considered to have the most reliable estimates of discharge for use in trend analysis. However, it is emphasized that trend analysis in R-QWTREND does not account for the uncertainty associated with the regression estimate for discharge at ungaged sites. Thus, the statistical significance will tend to be overestimated for ungaged sites where discharge is based completely on estimated discharge record, and the results of the trend analysis should be used with caution.

Analysis of the data in table 17 indicates that to maximize the likelihood of obtaining the best estimate of discharge at an ungaged site, a water-quality site would be on the same stream and within about 70 and 160 percent of the drainage area of the alternate streamgage site (DAR of 0.7 to 1.6). The alternate 

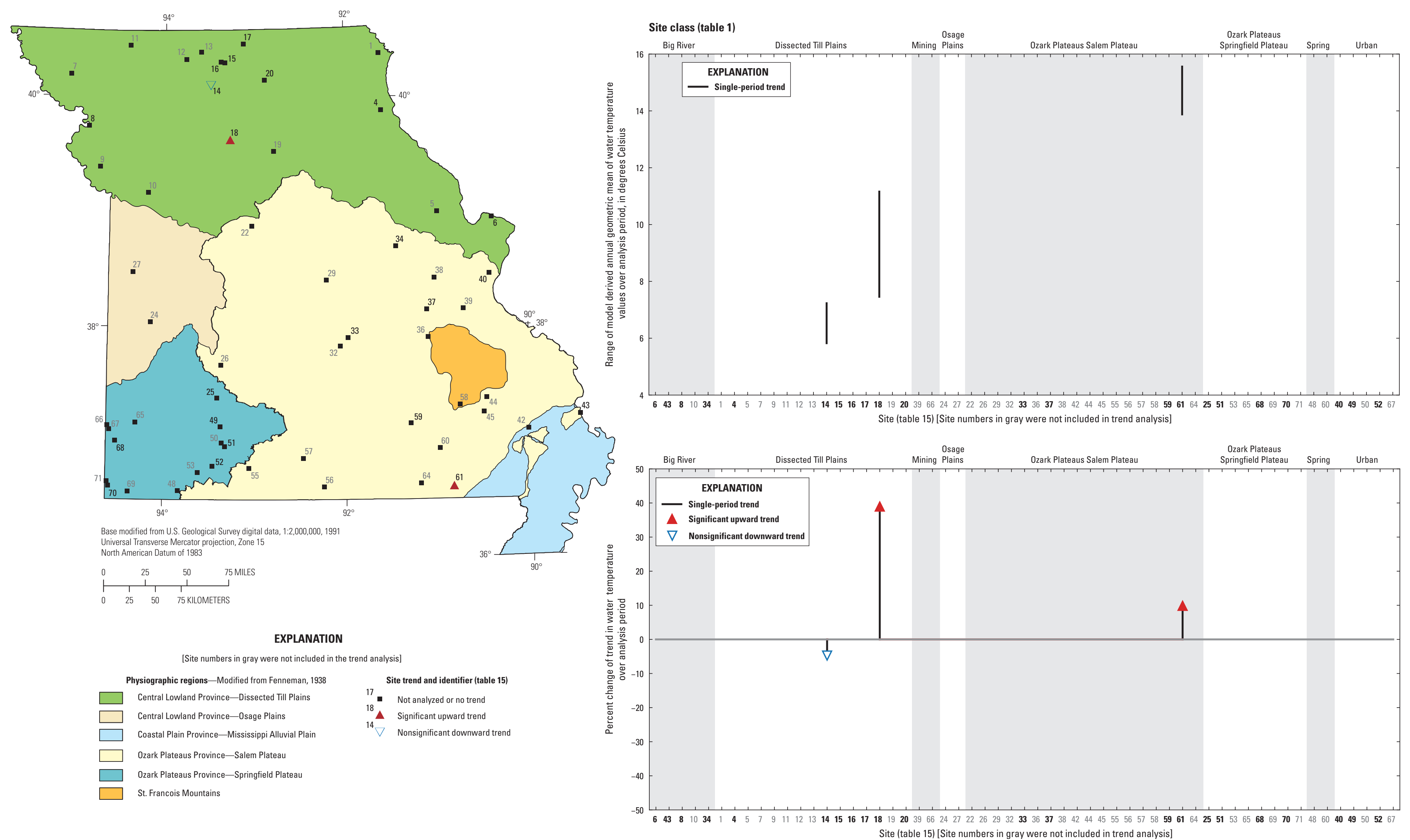

Figure 26. Water temperature trends computed from data resampled from monthly to quarterly frequency using the months March, June, September, and December (table 15). Site numbers in gray were not included in the analysis. 


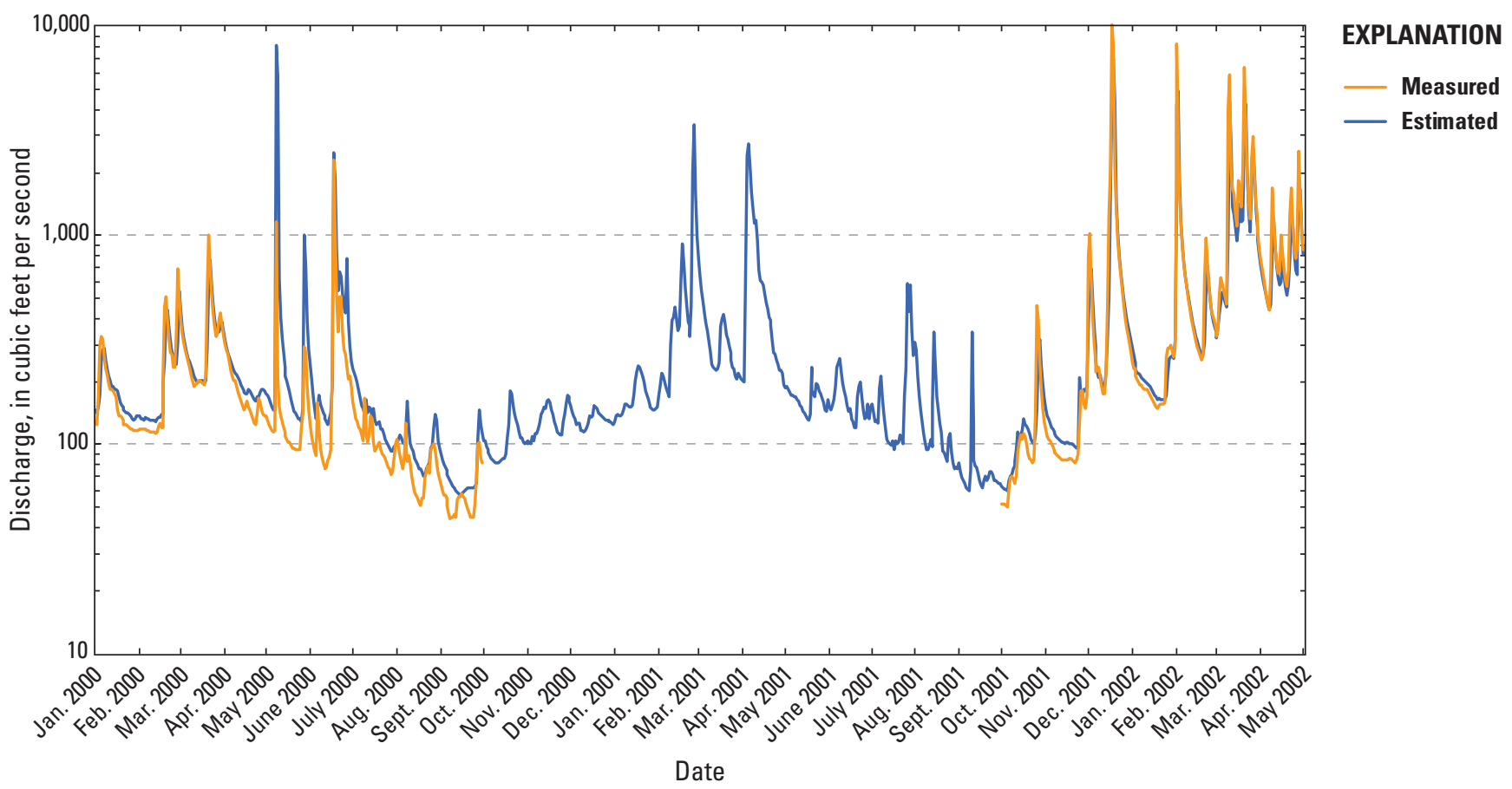

Figure 27. Comparison of estimated versus measured discharge for a short period surrounding a gap in the daily mean discharge record at site 39 (U.S. Geological Survey streamgage 07018100, Big River near Richwoods, Missouri).

site would need to have been active throughout the period when daily mean discharge is to be estimated at the ungaged site. To be able to use an alternate site to estimate discharge at the ungaged location, a sizeable dataset of measured discharge that is distributed throughout the range of discharge conditions at the ungaged site would need to be available to determine the appropriate regression model that can be used to estimate the daily mean discharge at the ungaged water-quality site. The measured discharge data distribution needs to be statistically tested against the daily mean discharge data distribution at the alternate site to determine if significant differences exist. If significant differences exist, it is recommended that the alternate site not be used or used with caution. It is recommended that the residuals from the regression model be tested for heteroscedasticity and if the test is significant, then the estimated discharge should be used with caution.

\section{Potentially Redundant Site Determination in the AWOMN}

Because redundant sites within a monitoring network may be adding additional expense with little additional interpretive value, the AWQMN was evaluated to identify potentially redundant sites. The grouping categories that were used to evaluate site pairs to determine site redundancy were class, Missouri and Mississippi Rivers, 4-digit HUC, 8-digit HUC, dominant land use, and watershed indicator site. All of these grouping categories except the Missouri and Mississippi
Rivers category are found in table 1 . Sites on the Missouri and Mississippi Rivers were grouped and analyzed separately. The results of the analysis can be found in tables 18, 19, 20, 21, 22, and 23. Each grouping category was evaluated independently, so the same site pairs may appear in multiple tables. For example, sites 1 and 2 are in the same physiographic province class (DTPL), 4-digit HUC (0711), 8-digit HUC (07110001), and land-use category (agriculture), so the pair 1-2 will appear in each of the appropriate tables. Site pairs were considered similar, and possibly redundant in the particular grouping category, if the mean of the percent of significant differences of the R_UNION and R_INTERSECTION aggregated results was less than 20 percent.

For all analyses, the site pairs $1-13,1-2,1-3,1-4$, 15-17, 16-17, 2-3, 2-4, and 4-5 were considered to be similar and possibly redundant in all grouping categories in which they appear. All of these sites are north of the Missouri River (fig. 1), in the DTPL Province (fig. 2), and are in the agriculture land-use class. The site pairs $1-2,1-3,1-4,2-3$, 2-4, and 4-5 are in the 4-digit HUC 0711, and site pairs 15-17 and 16-17 are in the 4-digit HUC 1028. The site pair 1-2 is in the 8-digit HUC 07110001, and the site pairs 15-17 and 16-17 are in the 8-digit HUC 10280103. As an example of how this information could be used, if the sampling design objectives were to monitor the water-quality health and determine trends at the 8-digit HUC level, then for 8-digit HUC 07110001, sites 1 and 2 may need to be evaluated further to determine if specific information from the data collected at these sites actually helps meet the design objective. If it is determined that data 
Table 19. Comparison of constituent data distributions for all possible pairs of sites on the Missouri and Mississippi Rivers (table 1).

[R_UNION aggregation significant difference for each site pair is defined as when a significant difference in a particular constituent is indicated in either the Kruskal-Wallace or Kuiper statistical test or both tests; R_INTERSECTION aggregation significant difference for each site pair is defined as when a significant difference in a particular constituent is indicated in both the Kruskal-Wallace and Kuiper statistical tests; KW, Kruskal-Wallace]

\begin{tabular}{lccccc}
\hline Site pair & $\begin{array}{c}\text { Number of KW and } \\
\text { Kuiper tests analyzed } \\
\text { for the site pair }\end{array}$ & $\begin{array}{c}\text { Percentage of tests } \\
\text { with no significant } \\
\text { difference }\end{array}$ & $\begin{array}{c}\text { Percentage of tests } \\
\text { using the R_UNION } \\
\text { aggregation }\end{array}$ & $\begin{array}{c}\text { Percentage of tests using } \\
\text { the R_INTERSECTION } \\
\text { aggregation }\end{array}$ & $\begin{array}{c}\text { Mean of the R_UNION } \\
\text { and R_INTERSECTION } \\
\text { aggregations }\end{array}$ \\
\hline $10-34$ & 13 & 8 & Missouri River \\
$10-8$ & 16 & 38 & 62 & 69 & 56 \\
$34-8$ & 13 & 0 & 100 & 62 & 59 \\
\hline $6-43$ & 16 & & Mississippi River & \\
\hline
\end{tabular}

at one or the other of these sites do not help meet the design objectives, then statistically speaking, removing one of the two sites would likely not change the distribution of the data in HUC 07110001 substantially, and probably would not change the interpretation of the water-quality health of the HUC.

It is emphasized that sites that are identified as similar, and possibly redundant in a particular grouping category, were only evaluated based on the similarity of the individual constituent data distributions, and all constituents were considered to be of equal value. This means that a site pair that meets the "similar" specifications, for example, may have significant differences in the constituents temperature and specific conductance, whereas a different site pair may have significant differences in the constituents DP and EC. In a basin where nutrients may be an issue, for the second similar pair, it may be useful to keep both sites, whereas for the first similar pair, it may not. It would be important to consider the constituent data, the site period of record, sampling frequency, geographic location, basin characteristics, whether the site is gaged or ungaged, and expected end use of the data for the site pairs considered to be similar, and possibly redundant in a particular grouping category, to determine if the site pairs are truly redundant.
Of equal importance to the possible existence of redundant sites in the AWQMN is the fact that the constituent data distributions at most of the sites in the grouping categories are significantly different. This difference indicates that most of the 71 AWQMN sites provide value and diversity to the overall collection of water-quality data for the network; therefore, adding additional sites or moving existing redundant sites to new locations would likely also enhance the network. Of special note is the analysis of the basins with designated watershed indicator sites (table 23) that monitor the integrated water-quality effects of the entire basin. It is evident that in all of these basins, constituent data distributions at the watershed indicator sites are significantly different from all of the sites upstream, so water-quality issues and trends of subbasins could be missed in these basins without additional monitoring sites distributed within the basin. 
Table 21. Comparison of constituent data distributions for all possible pairs of sites grouped by 8 digit hydrologic unit code (table 1).

[R UNION aggregation significant difference for each site pair is defined as when a significant difference in a particular constituent is indicated in either the Kruskal-Wallace or Kuiper statistical test or both tests; R_INTERSECTION aggregation significant difference for each site pair is defined as when a significant difference in a particular constituent is indicated in both the Kruskal-Wallace and Kuiper statistical tests; KW, Kruskal-Wallace]

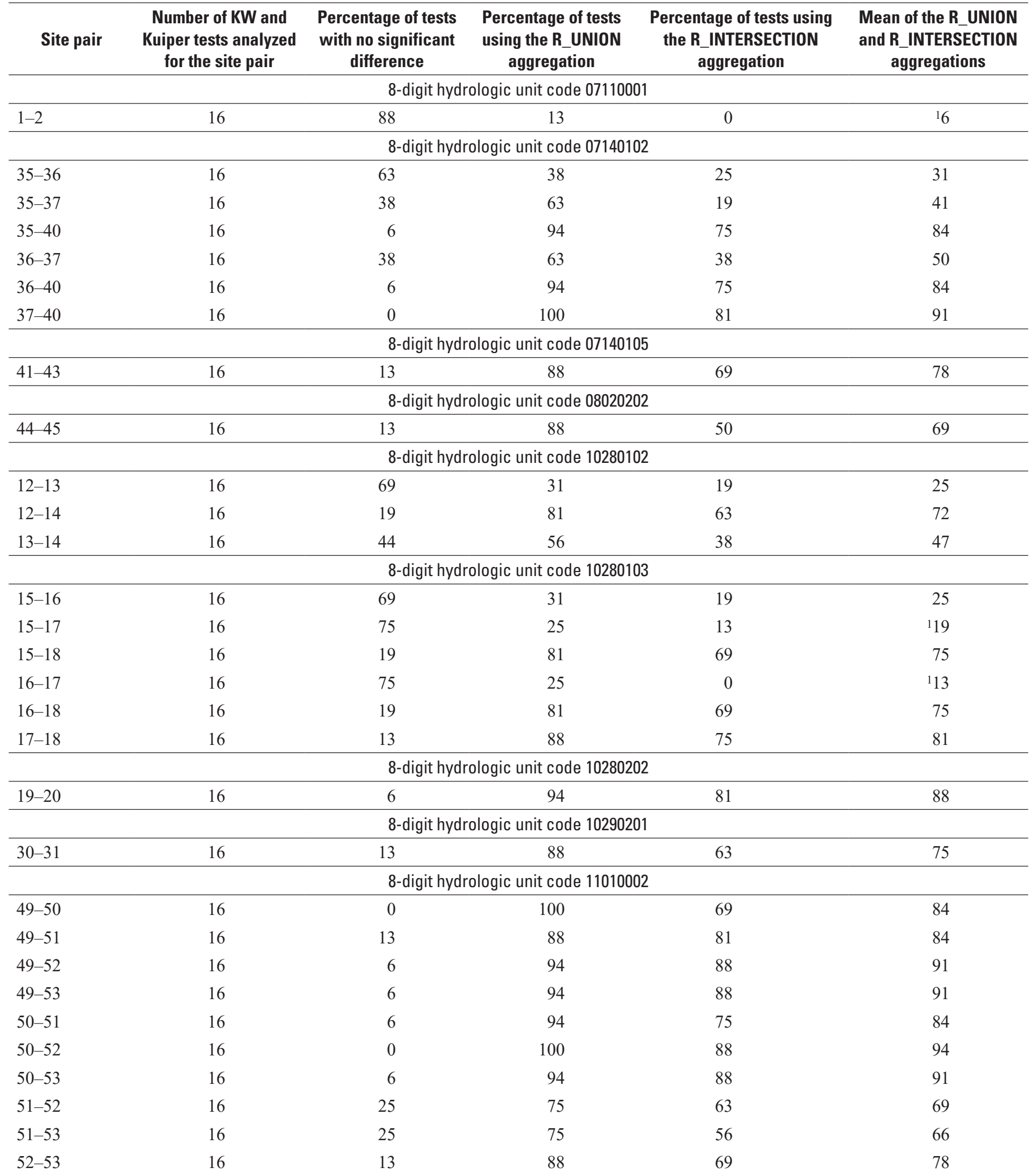


Table 21. Comparison of constituent data distributions for all possible pairs of sites grouped by 8 digit hydrologic unit code (table 1).Continued

[R_UNION aggregation significant difference for each site pair is defined as when a significant difference in a particular constituent is indicated in either the Kruskal-Wallace or Kuiper statistical test or both tests; R_INTERSECTION aggregation significant difference for each site pair is defined as when a significant difference in a particular constituent is indicated in both the Kruskal-Wallace and Kuiper statistical tests; KW, Kruskal-Wallace]

\begin{tabular}{|c|c|c|c|c|c|}
\hline Site pair & $\begin{array}{l}\text { Number of KW and } \\
\text { Kuiper tests analyzed } \\
\text { for the site pair }\end{array}$ & $\begin{array}{l}\text { Percentage of tests } \\
\text { with no significant } \\
\text { difference }\end{array}$ & $\begin{array}{l}\text { Percentage of tests } \\
\text { using the R_UNION } \\
\text { aggregation }\end{array}$ & $\begin{array}{c}\text { Percentage of tests using } \\
\text { the } R \text { INTERSECTION } \\
\text { aggregation }\end{array}$ & $\begin{array}{c}\text { Mean of the } R \_ \text {UNION } \\
\text { and } R \text { _INTERSECTION } \\
\text { aggregations }\end{array}$ \\
\hline \multicolumn{6}{|c|}{ 8-digit hydrologic unit code 11010003} \\
\hline $54-55$ & 15 & 44 & 50 & 31 & 41 \\
\hline \multicolumn{6}{|c|}{ 8-digit hydrologic unit code 11010006} \\
\hline \multicolumn{6}{|c|}{ 8-digit hydrologic unit code 11010008} \\
\hline $59-60$ & 16 & 38 & 63 & 38 & 50 \\
\hline $59-61$ & 16 & 31 & 69 & 44 & 56 \\
\hline $59-62$ & 16 & 13 & 88 & 69 & 78 \\
\hline $60-61$ & 16 & 44 & 56 & 31 & 44 \\
\hline $63-64$ & 16 & 50 & 50 & 31 & 41 \\
\hline \multicolumn{6}{|c|}{ 8-digit hydrologic unit code 11070207} \\
\hline $65-66$ & 16 & 19 & 81 & 56 & 69 \\
\hline $65-67$ & 16 & 13 & 88 & 75 & 81 \\
\hline $65-68$ & 16 & 31 & 69 & 56 & 63 \\
\hline $66-67$ & 16 & 6 & 94 & 88 & 91 \\
\hline $66-68$ & 16 & 31 & 69 & 56 & 63 \\
\hline $67-68$ & 16 & 0 & 100 & 81 & 91 \\
\hline \multicolumn{6}{|c|}{ 8-digit hydrologic unit code 11070208} \\
\hline
\end{tabular}

${ }^{1}$ Site pairs that may be considered statistically similar because they have a mean percentage of the R_UNION and R_INTERSECTION aggregations that is less than 20 . 
Table 23. Comparison of constituent data distributions for sites in the basins that have a watershed indicator site identified (table 1).

[R_UNION aggregation significant difference for each site pair is defined as when a significant difference in a particular constituent is indicated in either the Kruskal-Wallace or Kuiper statistical test or both tests; R_INTERSECTION aggregation significant difference for each site pair is defined as when a significant difference in a particular constituent is indicated in both the Kruskal-Wallace and Kuiper statistical tests; KW, Kruskal-Wallace]

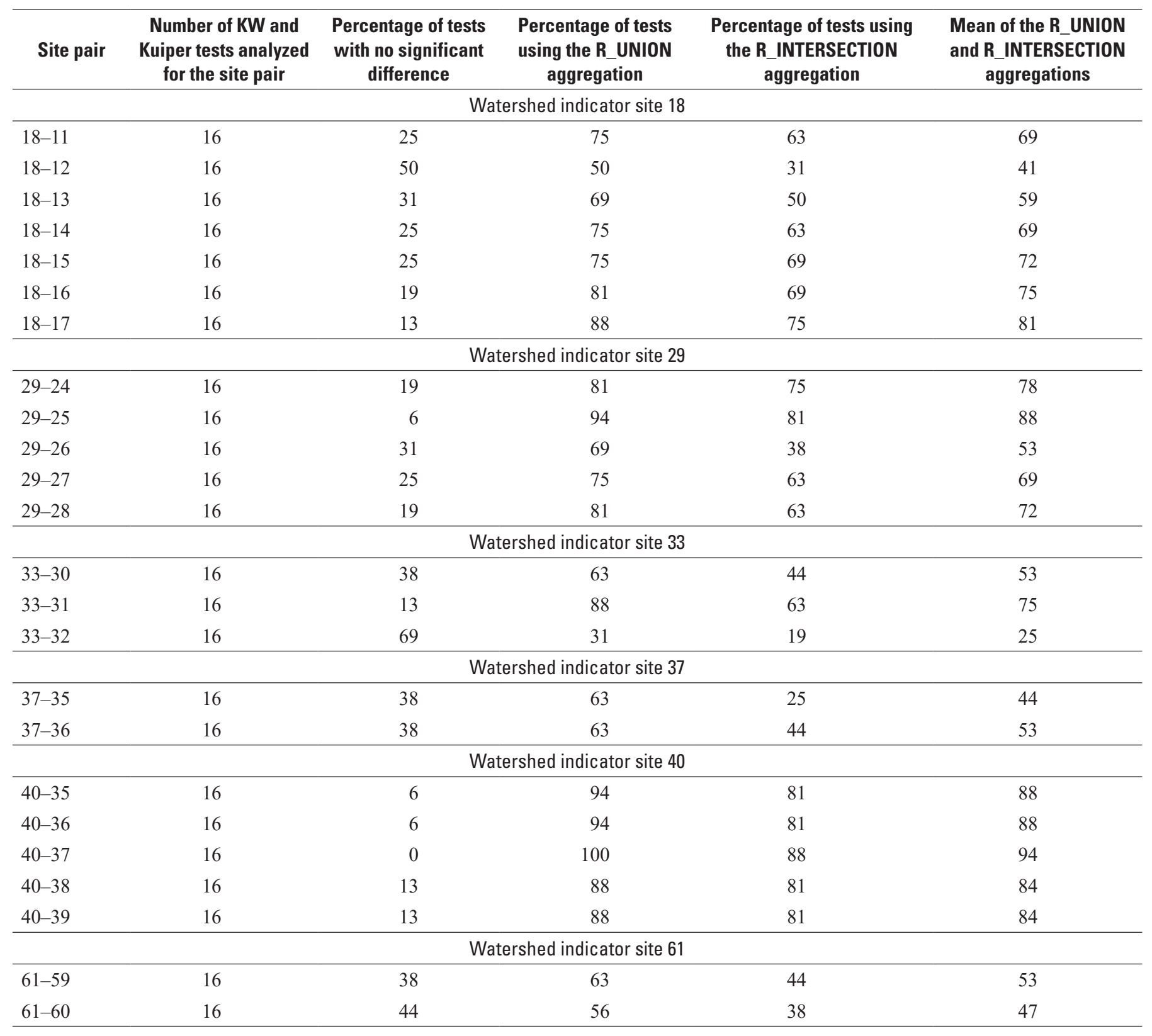




\section{Summary and Conclusions}

The U.S. Geological Survey, in cooperation with the Missouri Department of Natural Resources, collects data pertaining to the surface-water resources of Missouri. Established in 1964, the Ambient Water-Quality Monitoring Network (AWQMN) consisted of 69 sites in 2017. Two additional sites from the National Water-Quality Program are included with the AWQMN sites for the analyses in this report. The sites are sampled typically from 2 to 12 times per year for physical properties, total suspended solids, nutrients, fecal indicator bacteria, and trace elements. The period of analysis for this study was from 1993 through 2017 and data analysis included 71 sites and 15 water-quality constituents plus discharge. Data analysis involved retrieving the data, conditioning the data for analysis, analyzing the data for trends, and analyzing the monitoring network to determine if potential data gaps or data redundancies exist in the network.

The general water-quality conditions of the AWQMN sites tend to mimic the land use that dominates the basin. For example, agriculturally dominated areas tend to have higher concentrations of nutrients and fecal indicator bacteria, whereas forested areas tend to have lower concentrations of nutrients and fecal indicator bacteria. In some instances, concentrations of water-quality constituents at the AWQMN sites can exceed State water-quality standards and may be an indication of impairment of the water body. This impairment, coupled with some long-term upward trends for some constituents indicated at some sites, may be indicative of areas that warrant continued monitoring into the future. However, absence of trends does not necessarily preclude the need for future monitoring.

Long-term trends during the period 1993 through 2017 were analyzed for 15 water-quality constituents at 58 AWQMN sites, and results showed that significant single- or two-period trends were indicated in about 16 percent of the analyses. Some trends indicated improvement and some trends indicated deterioration to the general water quality at some sites. No trend was indicated in about 31 percent of the analyses, single- and two-period nonsignificant trends were indicated in about 5 percent of the analyses (which are essentially no trend), and about 48 percent did not meet the minimum data requirements for trend analysis. The constituents $\mathrm{pH}$, specific conductance, and total phosphorus showed the most frequent significant trends and each of the 15 constituents examined had a significant trend at one or more sites. A total of 42 sites indicated at least 1 significant single- or two-period trend, and 10 sites indicated 6 or more significant trends. Most of these 10 sites tended to represent basins classified as large or very large in size and most are likely heavily influenced by agricultural or urban activity. Eleven of the 16 sites with no significant trends were in the Ozark Plateaus Province, and all but one was a small or medium sized basin. Because significant trends in some constituents have occurred during the past 25 years, it is expected that changes in water quality will continue. Continued water-quality monitoring can be used to evaluate the eventual changes observed at the AWQMN sites.

In terms of spatial distribution, AWQMN sites monitor about 56 percent of the area of the State. Based on the 2017 number of sites in the AWQMN, a mean site density calculates to about 1 site per 1,000 square miles in Missouri. The 4-digit hydrologic unit code regions $0714,1028,1101$, and 1107 are overrepresented relative to the mean site density in Missouri, and the 4-digit hydrologic unit code regions $0711,0802,1024$, 1029, and 1030 are underrepresented relative to the mean site density in Missouri. The 8-digit hydrologic unit code regions with at least 500 square miles of area within the State and a site density greater than 2 are $07110001,10280102,11010002$, and 11070208 and might be considered overrepresented in terms of site density. The 8-digit hydrologic unit code regions with at least 800 square miles of area within the State and that contain no AWQMN sites are 07110004, 07110005, 07110006, 10240005, 10290109, 10300102, and 10300104 and may be considered underrepresented in terms of site density.

Discharge distribution, for the samples collected at the sites that had continuous discharge data, tended to be statistically similar to the daily mean discharge distribution for the period of analysis at these sites. The results of the examination of the discharge distribution for these sites indicated that the data collected at these sites tended to be better suited for analysis of water quality under general discharge conditions, and most sites in the AWQMN are not optimized for flux analysis. For flux analyses, which are often dominated by higher discharge conditions, it can be desirable to preferentially sample at higher discharges. For annual flux estimates, continuous discharge data at the site would be needed.

Of the 71 AWQMN sites, 47 had continuous discharge collected at or near the site and could be analyzed for discharge-weighted trends. For 21 sites with no continuous discharge, discharge was estimated from nearby streamgages, and three sites (two springs and a lake site) could not be estimated for discharge. Discharge estimates were determined to be adequate based on the regression fit at 11 sites and were used to analyze discharge-weighted trends. The most reliable discharge estimates were made from alternate streamgages that were on the same river and were within about 70 to 160 percent of the drainage area of the site to be estimated. Discharge at spring sites cannot typically be estimated from nearby streamgages; therefore, for long-term discharge-weighted water-quality trends to be computed for springs, concurrent collection of continuous discharge data would be needed.

Analysis of the AWQMN sampling frequency indicates that a sampling frequency of four or more samples per year would provide a statistically similar sample distribution as would be obtained from a monthly sample frequency during at least a 9-year period for the sites analyzed. For optimum data distribution while maintaining minimum sample collection, at least one sample would need to be collected in all seasons of the year and distributed as evenly as possible. Constituents that are likely to be frequently censored (trace elements 
and nutrients) would need to have their sample frequencies increased (greater than 4 times per year) to increase the likelihood of generating a dataset sufficient for trends analysis. When determining sampling frequency, it may be important to consider the intended use of the data in addition to optimizing the frequency. Reducing the sampling frequency may not affect the data distribution but may affect the ability to detect long-term discharge-weighted trends. A simulated reduction from monthly to quarterly sampling frequency at 22 sites was able to match about 46 percent of the analyses that indicated a significant single-period trend and about 65 percent of the analyses that indicated no trend.

For future trend analysis using statistically based discharge-weighted software such as R-QWTREND, it is important to ensure the data collected will meet the minimum requirements of the software. Currently (2020), these requirements include that continuous discharge data are available at the site during the analysis period, a minimum constituent sampling frequency (four per year) is maintained, sample collection is temporally distributed throughout the year (at least one sample per season), the proportion of censored data for a given constituent (less than 25 percent) is managed, and the sampling period (recommended minimum of 10 years) is of sufficient length. If the requirements are not met, trends may not be able to be analyzed, or the results may have to be interpreted with caution.

AWQMN sites analyzed using varying simulated sampling frequencies tended to be more sensitive to sampling frequency changes if they were in basins classified as large or very large size and tended to be least sensitive in basins classified as small and medium size in the Ozark Plateaus Province. Results indicated that lowering the sampling frequency of sites with small and medium size drainage basins in the Ozark Plateaus Province would tend to have the least effect on the ability of the network to detect trends. Simulated reduced frequency sampling analysis indicated that the constituents most sensitive to changes in sampling frequencies were water temperature, dissolved oxygen, discharge, and nitrate plus nitrite; least sensitive were $\mathrm{pH}$, total suspended solids, dissolved phosphorus, and total phosphorus.

In addition to the 8-digit hydrologic unit code regions that are potentially overrepresented in the AWQMN with respect to site density, several site pairs had statistically similar data distributions for some constituents and may represent site redundancies in the AWQMN. The site pairs are 1-13, $1-2,1-3,1-4,15-17,16-17,2-3,2-4$, and 4-5.

\section{References Cited}

Adamski, J.C., Petersen, J.C., Freiwald, D.A., and Davis, J.V., 1995, Environmental and hydrologic setting of the Ozark Plateaus study unit, Arkansas, Kansas, Missouri, and Oklahoma: U.S. Geological Survey Water-Resources Investigations Report 94-4022, 69 p.

Barr, M.N., 2010, Quality of surface water in Missouri, water year 2009: U.S. Geological Survey Open-File Report 2010-1233, 22 p., accessed March 17, 2020, at https://doi.org/10.3133/ofr20101233.

Barr, M.N., 2011, Quality of surface water in Missouri, water year 2010: U.S. Geological Survey Data Series 636, 21 p., accessed March 17, 2020, at https://doi.org/10.3133/ds636.

Barr, M.N., 2013, Quality of surface water in Missouri, water year 2011: U.S. Geological Survey Data Series 734, 22 p., accessed March 17, 2020, at https://doi.org/10.3133/ds734.

Barr, M.N., 2014, Quality of surface water in Missouri, water year 2012: U.S. Geological Survey Data Series 818, 24 p., accessed March 17, 2020, at https://doi.org/10.3133/ds818.

Barr, M.N., 2015, Quality of surface water in Missouri, water year 2014: U.S. Geological Survey Data Series 971, 22 p., accessed March 17, 2020, at https://doi.org/10.3133/ds971.

Barr, M.N., and Bartels, K.A., 2018, Quality of surface water in Missouri, water year 2016: U.S. Geological Survey Data Series 1086, 25 p., accessed August 20, 2019, at https://doi.org/10.3133/ds1086.

Barr, M.N., and Bartels, K.A., 2019, Quality of surface water in Missouri, water year 2017: U.S. Geological Survey Data Series 1108, 25 p., accessed May 26, 2019, at https://doi.org/10.3133/ds1108.

Barr, M.N., and Davis, J.V., 2010, Surface-water quality conditions and long-term trends at selected sites within the Ambient Water-Quality Monitoring Network in Missouri, 1993-2008: U.S. Geological Survey Scientific Investigations Report 2010-5078, 42 p. [Also available at https://doi.org/10.3133/sir20105078.]

Barr, M.N., and Heimann, D.C., 2016, Quality of surface water in Missouri, water year 2015: U.S. Geological Survey Data Series 1023, 22 p., accessed March 17, 2020, at https://doi.org/10.3133/ds1023.

Barr, M.N., and Schneider, R.E., 2014, Quality of surface water in Missouri, water year 2013: U.S. Geological Survey Data Series 886, 21 p., accessed March 17, 2020, at https://doi.org/10.3133/ds886. 
Bushon, R.N., Brady, A.M.G., Christensen, E.D., and Stelzer, E.A., 2017, Multi-year microbial source tracking study characterizing fecal contamination in an urban watershed: Water Environment Research, v. 89, no. 2, p. 127-143, accessed September 23, 2020, at https://doi.org/10.2175/ 106143016 X14798353399412.

Center for International Earth Science Information Network, 2017, U.S. Census Grids (Summary File 1), 2010: Palisades, N.Y., Center for International Earth Science Information Network, Columbia University, National Aeronautics and Space Administration, Socioeconomic Data and Applications Center (SEDAC), accessed March 2020 at https://doi.org/10.7927/H40Z716C.

Childress, C.J.O., Foreman, W.T., Connor, B.F., and Maloney, T.J., 1999, New reporting procedures based on long-term method detection levels and some considerations for interpretations of water-quality data provided by the U.S. Geological Survey National Water Quality Laboratory: U.S. Geological Survey Open-File Report 99-193, accessed March 2020 at https://doi.org/10.3133/ofr99193.

Collier, J.E., 1955, Geographic regions of Missouri: Annals of the Association of American Geographers, v. 45, no. 4, p. 368-392, accessed April 27, 2020, at http://www. jstor.org/stable/2561298.

Decker, W., and Guinan, P., 2016, Missouri drought: Agricultural Electronic Bulletin Board, University of Missouri Extension, accessed April 27, 2020, at http:/ /agebb.missouri.edu/drought/general-info/Understan dingMissouriDrought_2016.pdf.

Fenneman, N.M., 1938, Physiography of eastern United States: New York, McGraw-Hill Book Co., Inc., 689 p.

Fishman, M.J., ed., 1993, Methods of analysis by the U.S. Geological Survey National Water Quality LaboratoryDetermination of inorganic and organic constituents in water and fluvial sediments, U.S. Geological Survey OpenFile Report 93-125, 217 p. [Also available at https://doi.org/ 10.3133/ofr93125.]

Fishman, M.J., and Friedman, L.C., 1989, Methods for determination of inorganic substances in water and fluvial sediments: U.S. Geological Survey Techniques of WaterResources Investigations, book 5, chap. A1, 545 p. [Also available at https://doi.org/10.3133/twri05A1.]

Gray, J.R., Glysson, G.D., Turcois, L.M., and Schwarz, G.E., 2000, Comparability of suspended-sediment concentration and total suspended solids data: U.S. Geological Survey Water-Resources Investigations Report 00-4191, 20 p. [Also available at https://doi.org/10.3133/wri004191.]
Helsel, D.R., Hirsch, R.M., Ryberg, K.R., Archfield, S.A., and Gilroy, E.J., 2020, Statistical methods in water resources: U.S. Geological Survey Techniques and Methods, book 4, chap. A3, 458 p., accessed September 28, 2020, at https://doi.org/10.3133/tm4a3.

Hirsch, R.M., and De Cicco, L.A., 2015, User guide to Exploration and Graphics for RivEr Trends (EGRET) and data retrieval - $\mathrm{R}$ packages for hydrologic data (version 2.0, February 2015): U.S. Geological Survey Techniques and Methods, book 4, chap. A10, 93 p., accessed September 2020 at https://doi.org/10.3133/tm4A10.

Hunter, J., Dale, D., Firing, E., Droettboom, M., and the Matplotlib development team, 2020, Matplotlib user guide: accessed April 10, 2020, at https://matplotlib.org/stable/ users/index.html.

Intergovernmental Task Force on Monitoring Water Quality, 1995, The strategy for improving water-quality monitoring in the United States: U.S. Geological Survey OpenFile Report 95-742, accessed July 2020 at https://doi.org/ 10.3133 /ofr95742.

Kelly, W.R., Panno, S.V., Hackley, K.C., Hwang, H.-H., Martinsek, A.T., and Markus, M., 2010, Using chloride and other ions to trace sewage and road salt in the Illinois waterway: Applied Geochemistry, v. 25, no. 5, p. 661-673, accessed September 2020 at https://doi.org/10.1016/j.a pgeochem.2010.01.020.

Kuiper, N.H., 1960, Tests concerning random points on a circle: Proceedings of the Koninklijke Nederlandse Akademie van Wetenschappen, Series A, v. 63, p. 38-47. [Also available at https://doi.org/10.1016/S1385-7258(60)50006-0.]

Mallin, M.A., Williams, K.E., Esham, E.C., and Lowe, R.P., 2000, Effect of human development on bacteriological water quality in coastal watersheds: Ecological Applications, v. 10, no. 4, p. 1047-1056, accessed April 2, 2020, at https://doi.org/10.1890/1051-0761(2000)010 [1047:EOHDOB]2.0.CO;2.

Miller, D.E., and Vandike, J.E., 1997, Groundwater resources of Missouri: Missouri State Water Plan Series Volume II, Missouri Department of Natural Resources' Division of Geology and Land Survey, Water Resources Report No. 46, 210 p., accessed November 10, 2020, at https://nr.mo.gov/ pubs/WR46.pdf.

Missouri Climate Center, 2019, Historical temperature and precipitation charts for Missouri: Missouri Climate Center, University of Missouri School of Natural Resources, accessed April 27, 2020, at http://climate.missouri.edu/ charts.php. 
Missouri Department of Natural Resources, 2018a, Missouri integrated water quality report and section 303(d) list, 2018: Jefferson City, Mo., Missouri Department of Natural Resources, Water Protection Program, accessed April 29, 2020, at https://dnr.mo.gov/env/wpp/waterquality/303d/ documents/2018-305b-ir-final.pdf.

Missouri Department of Natural Resources, 2018b, Physiographic regions of Missouri: Map Sheet, Missouri Department of Natural Resources, Missouri Geological Survey, accessed April 27, 2020, at https://dnr.mo.gov/pubs/ docs/pub2515.pdf.

Missouri Department of Natural Resources, 2019, Rules of Department of Natural Resources, Division 20Clean Water Commission, Chapter 7-Water quality: Missouri Department of Natural Resources, Code of State Regulations, 10 CSR 20-7, p. 54-131, accessed August 19, 2020, at https://www.sos.mo.gov/cmsimages/adrules/csr/ current/10csr/10c20-7a.pdf.

Missouri Department of Natural Resources, 2020, Missouri lead mining history by county: accessed September 10, 2020, at https://dnr.mo.gov/env/hwp/sfund/lead-mo-historymore.htm.

Missouri Spatial Data Information Service, 2020, Missouri Spatial Data Information Service, University of MissouriColumbia: accessed May 2020, at https://msdis.mis souri.edu/.

Mugel, D.N., 2017, Geology and mining history of the Southeast Missouri Barite District and the Valles Mines, Washington, Jefferson, and St. Francois Counties, Missouri: U.S. Geological Survey Scientific Investigations Report 2016-5173, 61 p. [Also available at https://doi.org/10.3133/ sir20165173.]

Mugel, D.N., Richards, J.M., and Schumacher, J.G., 2009, Geohydrologic investigations and landscape characteristics of areas contributing water to springs, the Current River, and Jacks Fork, Ozark National Scenic Riverways, Missouri: U.S. Geological Survey Scientific Investigations Report 2009-5138, 80 p. [Also available at https://doi.org/ 10.3133/sir20095138.]

Multi-Resolution Land Characteristics Consortium, 2020, 2016 National Land Cover Database: Multi-Resolution Land Characteristics Consortium, accessed May 15, 2020, at https://www.mrlc.gov/.

Nustad, R.A., and Vecchia, A.V., 2020, Water-quality trends for selected sites and constituents in the international Red River of the North Basin, Minnesota and North Dakota, United States, and Manitoba, Canada, 1970-2017:

U.S. Geological Survey Scientific Investigations Report 2020-5079, 75 p., accessed November 2020, at https://doi.org/10.3133/sir20205079.
Otero-Benítez, W., and Davis, J.V., 2009a, Quality of surface water in Missouri, water year 2007: U.S. Geological Survey Open-File Report 2009-1096, 19 p. [Also available at https://doi.org/10.3133/ofr20091096.]

Otero-Benítez, W., and Davis, J.V., 2009b, Quality of surface water in Missouri, water year 2008: U.S. Geological Survey Open-File Report 2009-1214, 18 p. [Also available at https://doi.org/10.3133/ofr20091214.]

Paltani, S., 2004, Searching for periods in X-ray observations using Kuiper's test: Astronomy \& Astrophysics, v. 420, no. 2, p. 789-797, accessed November 2020 at https://doi.org/10.1051/0004-6361:20034220.

R Core Team, 2020, R-A language and environment for statistical computing: Vienna, Austria, R Foundation for Statistical Computing, accessed November 2020 at https://www.R-project.org/.

Richards, J.M., and Barr, M.N., 2021, Supporting data for analysis of general water-quality conditions, long-term trends, and network analysis at selected sites within the Ambient Water-Quality Monitoring Network in Missouri, water years 1993-2017: U.S. Geological Survey data release, https://doi.org/10.5066/P9R2R9DF.

Sauer, V.B., 2001, Standards for the analysis and processing of surface-water data and information using electronic methods: U.S. Geological Survey WaterResources Investigations Report 01-4044, 91 p., accessed November 2020 at https://doi.org/10.3133/wri20014044.

SciPy Community, 2014, SciPy reference guide release 0.14.0: accessed April 4, 2020, at https://docs.scipy.org/doc/scipy0.14.0/reference/generated/scipy.stats.spearmanr.html\#crcpr obstat2000.

Seaber, P.R., Kapinos, F.P., and Knapp, G.L., 1987, Hydrologic-unit maps: U.S. Geological Survey Water Supply Paper 2294, 63 p. [Also available at https://doi.org/ 10.3133/wsp2294.]

Seabold, S., and Perktold, J., 2010, statsmodels-Econometric and statistical modeling with python, in Proceedings of the 9th Python in Science Conference: accessed November 2020 at http://conference.scipy.org/proceedings/ scipy2010/pdfs/seabold.pdf.

Smith, D.C., 2016, Occurrence, distribution, and volume of metals-contaminated sediment of selected streams draining the Tri-State Mining District, Missouri, Oklahoma, and Kansas, 2011-12: U.S. Geological Survey Scientific Investigations Report 2016-5144, 86 p., accessed November 2020 at https://doi.org/10.3133/sir20165144. 
Starbuck, E.A., comp., 2017, Geologic map of Missouri: Missouri Department of Natural Resources, Missouri Geological Survey, accessed April 27, 2020, at https://dnr.mo.gov/geology/documents/2017-statewidegeologic-map.pdf.

State of Missouri, [undated], Learn about Missouri: State of Missouri website, accessed April 29, 2020, at https://www.mo.gov/education/learn-about-missouri.

Turnipseed, D.P., and Sauer, V.B., 2010, Discharge measurements at gaging stations: U.S. Geological Survey Techniques and Methods, book 3, chap. A8, 87 p., accessed November 2020 at https://doi.org/10.3133/tm3A8.

U.S. Census Bureau, 2020, U.S. Census Bureau quickfacts for Missouri: accessed April 15, 2020, at https://www.c ensus.gov/quickfacts/MO.

U.S. Department of Commerce, 2013, Kolmogorov-Smirnov Goodness-of-Fit Test: e-Handbook of Statistical Methods, National Institute of Standards and Technology, U.S. Department of Commerce, accessed April 29, 2020, at https://www.itl.nist.gov/div898/handbook/eda/section3/ eda35g.htm.

U.S. Department of Commerce, 2015, Rank correlation independence test: e-Handbook of Statistical Methods, National Institute of Standards and Technology, U.S. Department of Commerce, accessed April 29, 2020, at https://www.itl.nist.gov/div898/software/dataplot/refman1/ auxillar/rankcorr.htm.

U.S. Department of Commerce, 2016, Kolmogorov-Smirnov two sample: Dataplot documentation, National Institute of Standards and Technology, U.S. Department of Commerce, accessed April 29, 2020, at https://www.itl.nist.gov/div898/ software/dataplot/refman1/auxillar/ks2samp.htm.

U.S. Environmental Protection Agency, 1997, Guidelines for preparation of comprehensive state water quality assessments (305(b) reports) and electronic updates: Washington, D.C., Office of Water, EPA-841-B97-002A, [variously paged], accessed July 2009 at https://www.epa.gov/owow/ monitoring/guidelines.html.

U.S. Geological Survey, 2019a, WaterWatch, U.S. Geological Survey: accessed December 2019, at http://wwsrvvm.cr .usgs.gov/.

U.S. Geological Survey, 2019b, Metals and other trace elements, U.S. Geological Survey: accessed December 2019 at https://www.usgs.gov/mission-areas/water-resources/ science/metals-and-other-trace-elements?qt-science_center objects $=0 \#$ qt-science_center_objects.
U.S. Geological Survey, 2020, USGS water data for the Nation: U.S. Geological Survey National Water Information System database, accessed April 15, 2020, at https://doi.org/ 10.5066/F7P55KJN.

Vecchia, A.V., and Nustad, R.A., 2020, Time-series model, statistical methods, and software documentation for RQWTREND - An R package for analyzing trends in stream-water quality: U.S. Geological Survey Open-File Report 2020-1014, 51 p., accessed November 2020 at https://doi.org/10.3133/ofr20201014.

Vineyard, J.D., and Feder, G.L., 1974, Springs of Missouri: Rolla, Missouri Department of Natural Resources, Division of Geology and Land Survey Water Resources Report No. $29,266 \mathrm{p}$.

Virtanen, P., Gommers, R., Oliphant, T.E., Haberland, M., Reddy, T., Cournapeau, D., Burovski, E., Peterson, P., Weckesser, W., Bright, J., van der Walt, S.J., Brett, M., Wilson, J., Millman, K.J., Mayorov, N., Nelson, A., Jones, E., Kern, R., Larson, E., Carey, C.J., Polat, İ., Feng, Y., Moore, E.W., VanderPlas, J., Laxalde, D., Perktold, J., Cimrman, R., Henriksen, I., Quintero, E.A., Harris, C.R., Archibald, A.M., Ribeiro, A.H., Pedregosa, F., van Mulbregt, P., and SciPy 1.0 Contributors, 2020, SciPy 1.0 Fundamental algorithms for scientific computing in Python: Nature Methods, v. 17, no. 3, p. 261-272. [Also available at https://doi.org/10.1038/s41592-019-0686-2.]

White, H.L., 1980, A heteroskedasticity-consistent covariance matrix estimator and a direct test for heteroskedasticity: Econometrica, v. 48, no. 4, p. 817-838. [Also available at https://doi.org/10.2307/1912934.]

Williams, R., 2020, Heteroskedasticity: University of Notre Dame, accessed May 29, 2020, at https://www3.nd.edu/ rwilliam/stats2/125.pdf. 
For more information about this publication, contact: Director, USGS Central Midwest Water Science Center 1400 Independence Road

Rolla, M0 65401

573-308-3667

For additional information, visit: https://www.usgs.gov/ centers/cm-water

Publishing support provided by the

Rolla Publishing Service Center 
